\title{
Synthesis of spiro-fused heterocyclic scaffolds through multicomponent reactions involving isatin
}

\author{
Ghodsi Mohammadi Ziarani, ${ }^{\mathrm{a}}$ Razieh Moradi, ${ }^{a}$ and Negar Lashgari ${ }^{\mathrm{b}}$ \\ ${ }^{a}$ Department of Chemistry, Alzahra University, Vanak Square, Tehran, \\ P. O. Box 1993891176, Iran \\ ${ }^{b}$ School of Chemistry, College of Science, University of Tehran, Tehran, Iran \\ E-mail: gmziarani@hotmail.com;gmohammadi@alzahra.ac.ir
}

DOI: http://dx.doi.org/10.3998/ark.5550190.p009.385

\begin{abstract}
Isatin has been utilized in many heterocyclic preparations and considered as an important building block in organic synthesis. There is a wide range of multi-component reactions that include isatin in the synthesis of heterocyclic compounds. This review highlights the advances in the use of isatin as starting material in the synthesis of various organic compounds and drugs during the period from 2012 to 2015 .
\end{abstract}

Keywords: Isatin, spiro-fused compounds, multi-component reactions, heterocyclic synthesis

\section{Table of Contents}

1. Introduction

2. Synthesis of Isatin-Based Spiro-Fused Frameworks

2.1 Synthesis involving three-component reactions of isatins

2.1.1 Five-membered spiro-fused compounds

2.1.2 Six-membered spiro-fused compounds

2.2 Synthesis involving four-component reactions of isatins

2.2.1 Five-membered spiro-fused compounds

2.2.2 Six-membered spiro-fused compounds

2.3. Synthesis involving five-component reactions of isatins

3 Conclusions

Acknowledgements

References 


\section{Introduction}

Isatin is a natural product found in plants of the genus Isatis $^{1}$ that was first obtained by Erdmann ${ }^{2}$ and Laurent ${ }^{3}$ in 1840 as a product from the oxidation of indigo dye by nitric acid and chromic acid. Substituted isatin analogues constitute valuable building blocks for potential pharmaceuticals with a wide range of biological properties such as antimicrobial, ${ }^{4}$ antitumor, ${ }^{5-8}$ antitubercular, ${ }^{9-10}$ antimalaria, ${ }^{11}$ anti-HIV, ${ }^{12}$ and antibacterial. ${ }^{13}$

Furthermore, isatin is a core constituent of many drugs. For example, spirotetrahydro $\beta$ carboline is amenable to a single or low dose oral treatment for malaria, ${ }^{14} N$-methylisatin- $\beta, 4^{\prime}, 4^{\prime}$ diethylthiosemicarbazone (M-IBDET) specifically inhibits formation of Moloney leukemia virus structural proteins, ${ }^{15}$ and the indenoquinoline compounds, NSC 706744 , NSC 725776 and NSC 724998 show prominent antitumor activities (Figure 1). ${ }^{16}$

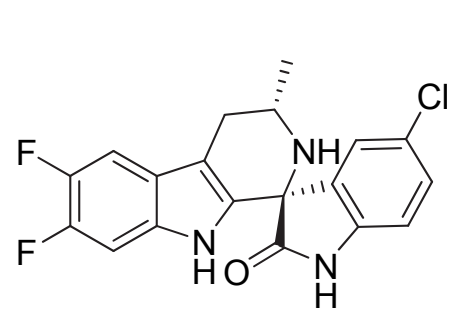

Antimalarial

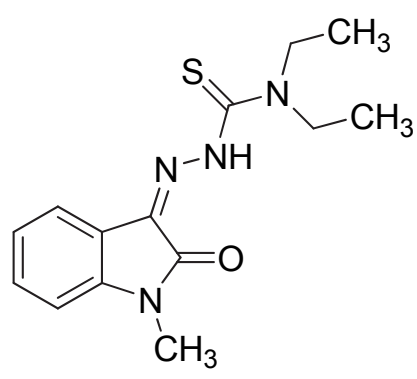

(M-IBDET)<smiles></smiles>

NSC 706744

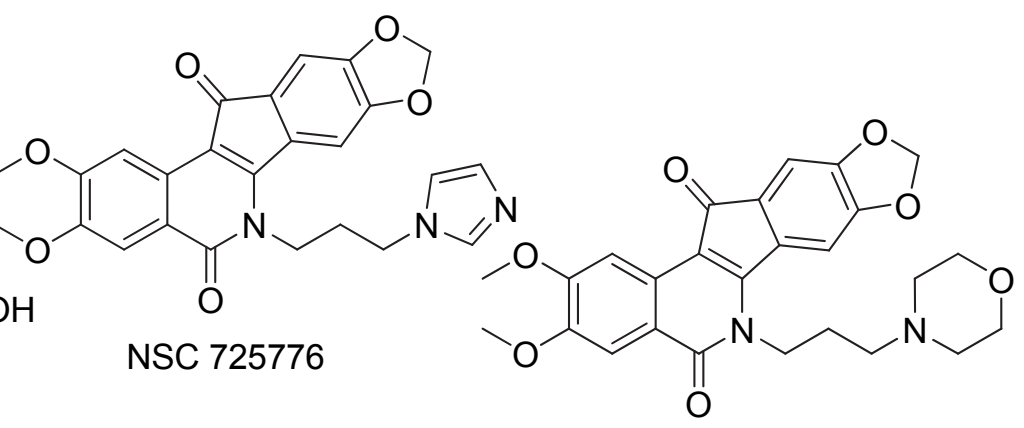

NSC 724998

\section{Figure 1}

Isatin and its derivatives accomplish various reactions for the synthesis of organic compounds; Schiff bases of isatin are used for their pharmaceutical properties ${ }^{17}$ and spirooxindoles have significant biological activities. ${ }^{18,19}$ The chemistry of isatins was reviewed for the first time by Sumpter ${ }^{20}$ and later updated by Popp ${ }^{21}$ and da Silva et al. ${ }^{22}$ In recent years isatin-related review articles have been published on enantioselective reactions with isatin, ${ }^{23-25}$ biochemical and pharmacological characterization of isatin and its derivatives, ${ }^{26}$ isatins as privileged molecules in design and synthesis of spiro-fused cyclic frameworks, ${ }^{27}$ recent progress on routes to spirooxindole systems derived from isatin, ${ }^{28}$ synthesis of spiro ${ }^{29}$ and multispiro ${ }^{30}$ 
heterocyclic compounds from isatin, the use of water in the synthesis of isatin based spirocyclic compounds, ${ }^{31}$ and synthesis of heterocyclic compounds based on isatin through 1, 3-dipolar cycloaddition reactions. $^{32}$

Considering the importance of isatin as a building block in organic synthesis, and since there is a wide range of reactions that include isatin in the synthesis of heterocyclic compounds, this review gives an overview of the synthesis of different types of spiro-fused heterocyclic scaffolds through multicomponent reactions from the year 2012 to 2015 in which one of the starting materials is isatin.

\section{Synthesis of Isatin-Based Spiro-Fused Frameworks}

Isatins have been employed in the architecture of different types of spiro-heterocyclic frameworks. This section involves a range of multi-component reactions involving isatin, starting with the synthesis of five-membered spiro-fused compounds trouth three-component reactions. Then, the synthesis of six-membered spiro-fused compounds, four-component and five-component reactions of isatin are presented.

\subsection{Synthesis involving three-component reactions of isatins}

The design of reactions involving three or more different starting materials, usually referred to as multicomponent reactions (MCRs) has become an important area of research in organic, medicinal, and combinatorial chemistry. ${ }^{33-36}$ Some advantages of MCRs involve minimization of the reagents, solvents, cost, and time. Other advantages, which make MCRs an effective tool for synthetic chemists, are ease of separation thus avoiding the complicated purification procedures and also minimizing the formation of chemical waste.

2.1.1. Five-membered spiro-fused compounds. Rajanarendar's group synthesized a series of isoxazoles $\mathbf{4}$ by the three component reaction of isoxazole acetic acid $\mathbf{2}$ with substituted isatins $\mathbf{1}$ and 1,4-naphthoquinone $\mathbf{3}$ using Ceric ammonium nitrate (CAN) catalyst under aerial oxidation condition (Scheme 1). ${ }^{37}$ The plausible mechanism involves the 1,3-dipolar cycloaddition of azomethine ylide, generated in situ via decarboxylative condensation of isatin with isoxazole acetic acid to 1,4-naphthoquinone activated by CAN, followed by dehydrogenation under aerial oxidation condition affords the desired compound. The compounds were evaluated for their antiinflammatory and analgesic activity. 
<smiles>[R]c1ccc2c(c1)C(=O)C(=O)N2</smiles>

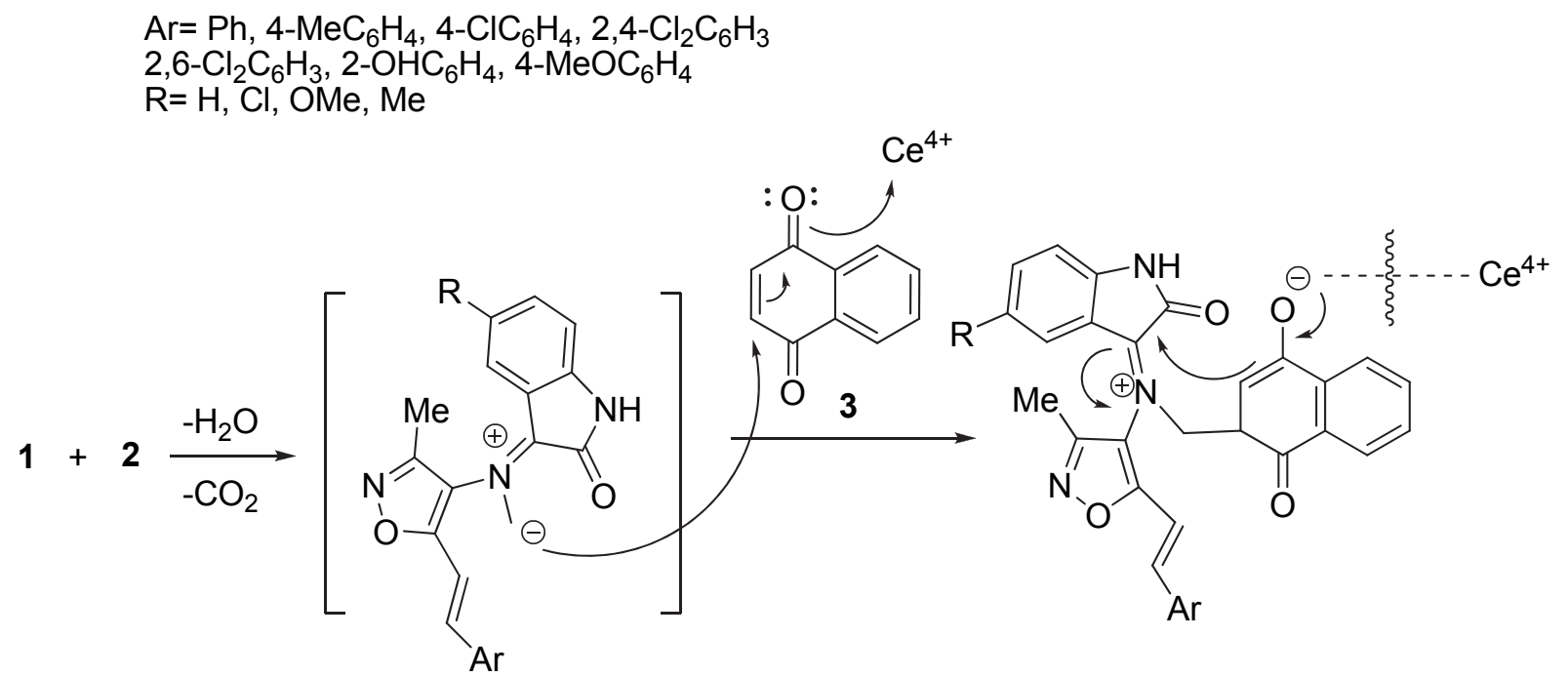<smiles>[R]c1ccc2c(c1)C1(C(=O)N2)[C@@H]2C(=O)c3ccccc3C(=O)[C@@H]2CN1c1c(C)noc1/C=C/[Ga]</smiles>

B

\section{Scheme 1}

The synthesis of spirooxindolopyrrolidines $\mathbf{7}$ and $\mathbf{1 1}$ and spiropyrrolizidines $\mathbf{1 2}$ by utilizing a 1,3-dipolar cycloaddition of hitherto uninvestigated acrylamides $\mathbf{6}$ and aroylacrylic acids $\mathbf{8}$ with azomethine ylides, generated in situ via decarboxylative condensation of isatins $\mathbf{1}$ and $\mathrm{N}$ substituted $\alpha$-amino acids 5, 9, and $\mathbf{1 0}$ in a three-component fashion was reported by Lipson and co-workers (Schemes 2 and 3). ${ }^{38}$ 


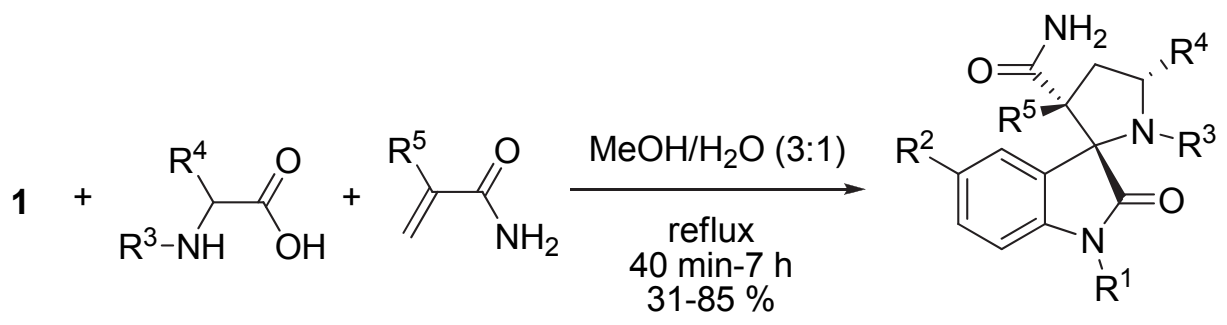

5

6

$\mathrm{R}^{1}=\mathrm{H}, \mathrm{Me}, 4-\mathrm{ClC}_{6} \mathrm{H}_{4} \mathrm{CH}_{2}$

$\mathrm{R}^{2}=\mathrm{H}, \mathrm{Br}, \mathrm{NO}_{2}$

$\mathrm{R}^{3}=\mathrm{Me}, \mathrm{CH}_{2} \mathrm{CH}_{2} \mathrm{CH}_{2}, \mathrm{CH}_{2} \mathrm{SCH}_{2}$

$\mathrm{R}^{4}=\mathrm{H}, \mathrm{CH}_{2} \mathrm{CH}_{2} \mathrm{CH}_{2}, \mathrm{CH}_{2} \mathrm{SCH}_{2}$

$\mathrm{R}^{5}=\mathrm{H}, \mathrm{Me}$

\section{Scheme 2}

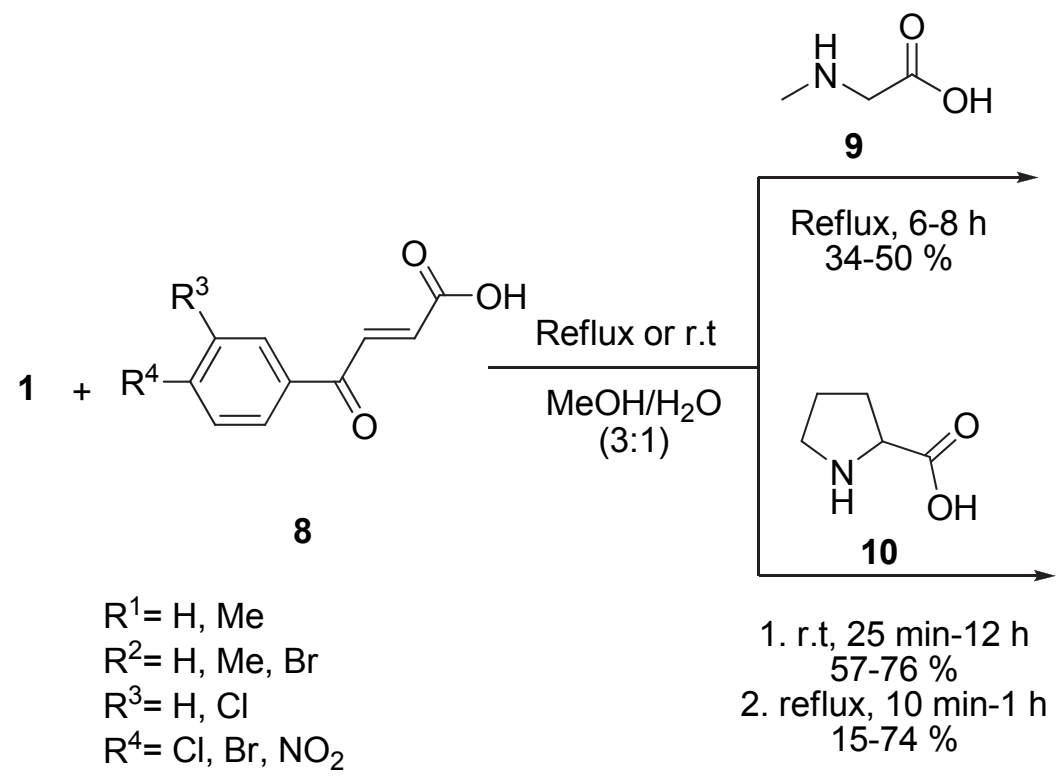

\section{Scheme 3}

Synthesis of some biologically interesting spiro-indolone-pyrrolidine derivatives $\mathbf{1 5}$ was accomplished by 1,3-dipolar cycloaddition reaction of azomethine ylide generated in situ from isatin 1 and benzylamine 13 with the substituted $\alpha, \beta$-unsaturated carbonyl compounds 14 as dipolarophile, leading to the formation of new 4-aryl-3-benzoyl-5-phenylspiro[pyrrolidine-2.3'indolin]-2'-one derivatives 15 stereoselectively in excellent yields (Scheme 4). ${ }^{39}$ The synthesized compounds have been screened for their advanced glycation end (AGE) product formation 
inhibitory activity. In another study, the molecular mechanism of this cycloaddition has been investigated by means of a density functional theory (DFT) method. ${ }^{40}$

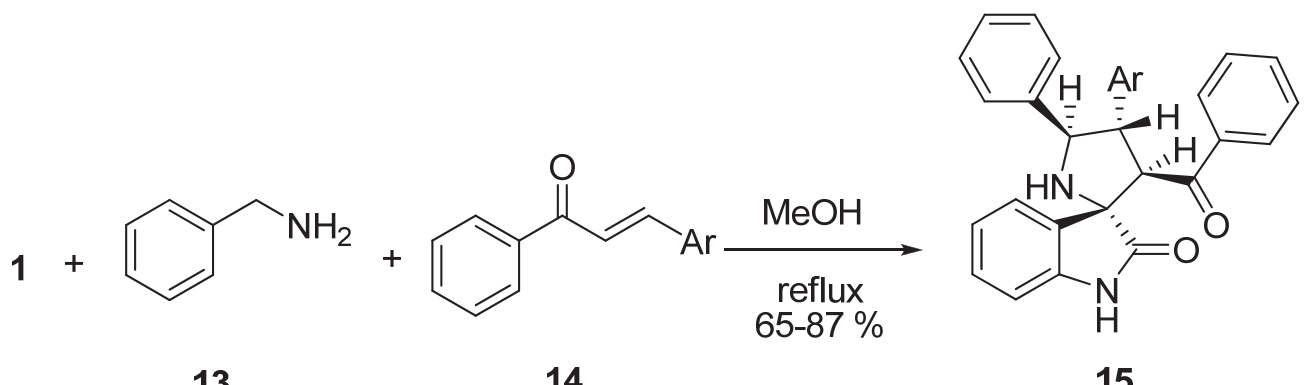

13

14

15

$\mathrm{Ar}=\mathrm{Ph}, 4-\mathrm{ClC}_{6} \mathrm{H}_{4}, 4-\mathrm{OMeC}_{6} \mathrm{H}_{4}, 4-\mathrm{NO}_{2} \mathrm{C}_{6} \mathrm{H}_{4}, 4-\mathrm{OHC}_{6} \mathrm{H}_{4}$, $4-\mathrm{NMe}_{2} \mathrm{C}_{6} \mathrm{H}_{4}, 3,4-(\mathrm{OMe})_{2} \mathrm{C}_{6} \mathrm{H}_{3}, 2-\mathrm{ClC}_{6} \mathrm{H}_{4}, \mathrm{CH}=\mathrm{CH}-\mathrm{C}_{6} \mathrm{H}_{5}$

\section{Scheme 4}

Huang et al. conducted a catalyst-free, one-pot, three-component process employing isatins 1, tert-butyl 2-aminoacetate hydrochloride 16, and benzophenone imine $\mathbf{1 7}$ for the synthesis of biologically interesting unnatural amino-acids containing 3-hydrooxindole skeleton 19 (Scheme $5) .{ }^{41}$ The strategy involves the formation of two new quaternary centers in high yields and with a broad substrate scope.

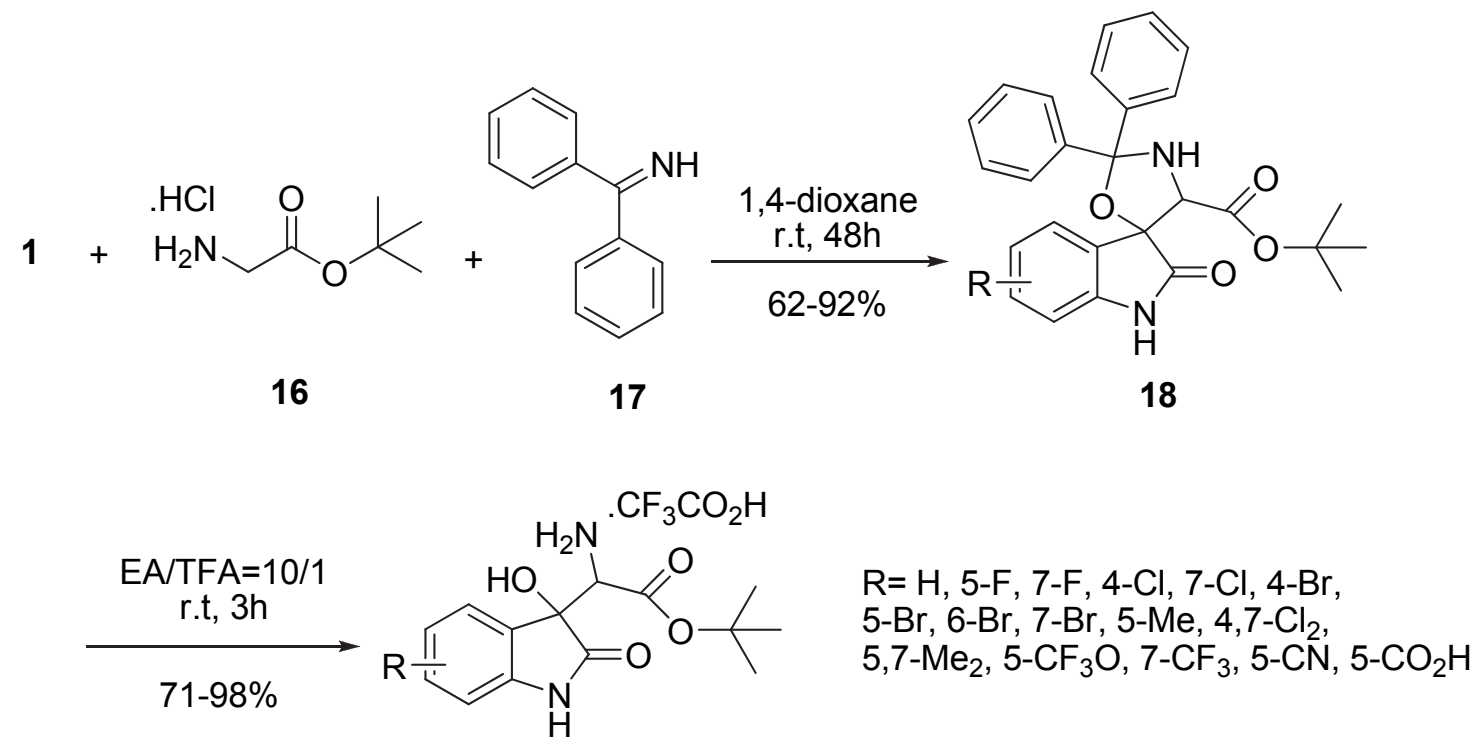

19

\section{Scheme 5}

The three-component 1,3-dipolar cycloaddition reaction of substituted isatins $\mathbf{1}$ and primary $\alpha$-amino acid methyl ester $\mathbf{2 0}$ with the Knoevenagel adducts of substituted isatin $\mathbf{2 1}$ resulted in 
the formation of novel spiropyrrolidine bisoxindoles 22 in high yields (up to 99\%) (Scheme 6). ${ }^{42}$<smiles>[R]C=C1C(=O)Nc2ccc([ClH+])cc21</smiles>

20

$$
\begin{aligned}
& \mathrm{R}^{1}=\mathrm{H}, \mathrm{Bn}, \mathrm{Et} \\
& \mathrm{R}^{2}=\mathrm{H}, \mathrm{Br}, \mathrm{Me} \\
& \mathrm{R}^{3}=\mathrm{Ph}, 4-\mathrm{FC}_{6} \mathrm{H}_{4}, 4-\mathrm{BrC}_{6} \mathrm{H}_{4}, \\
& \text { 3,4-(MeO) }{ }_{2} \mathrm{C}_{6} \mathrm{H}_{3}, \text { Pyridin-3-yl }
\end{aligned}
$$

\section{Scheme 6}

A new spiro[indole-3,3'-pyrrolizine] derivative $\mathbf{2 4}$ was regioselectively synthesized by the multicomponent reaction of isatin 1, 1-(4-fluorophenyl)-3-phenylprop-2-en-1-one 23, and $L$ proline 10 (Scheme 7). ${ }^{43}$ The possible mechanism of this reaction was investigated using a B3LYP/6-311G level of theory, and the results show that the regioselection depends on the energy barrier between the stacking state and the regioisomer. ${ }^{44}$

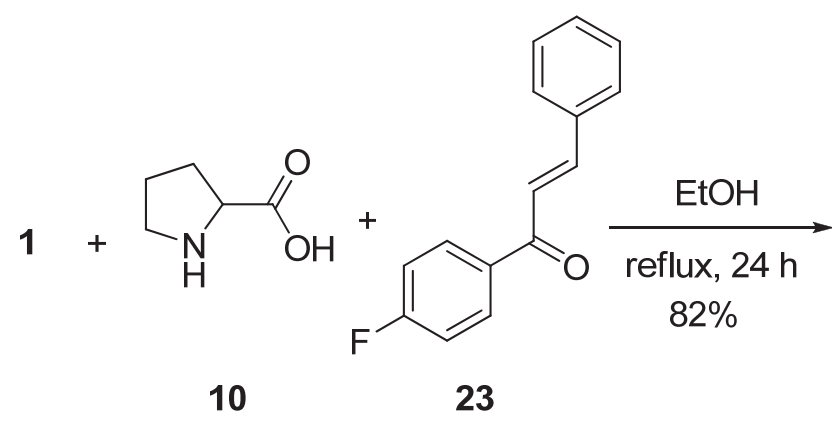

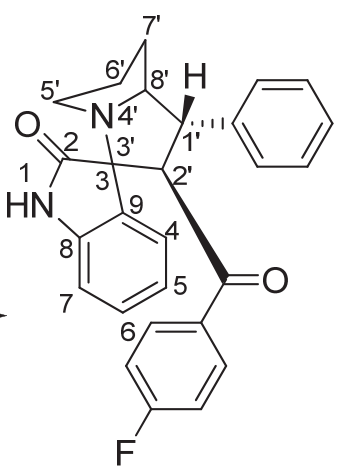

24

\section{Scheme 7}

A synthetic route for the preparation of novel dispirooxindoles $\mathbf{2 6}$ has been achieved via 1,3-dipolar cycloaddition of azomethine ylides generated in situ by the decarboxylative condensation of isatins $\mathbf{1}$ and L-proline $\mathbf{1 0}$ with the dipolarophile 5-benzylideneimidazolidine2,4-dione 25 (Scheme 8). ${ }^{45}$ 


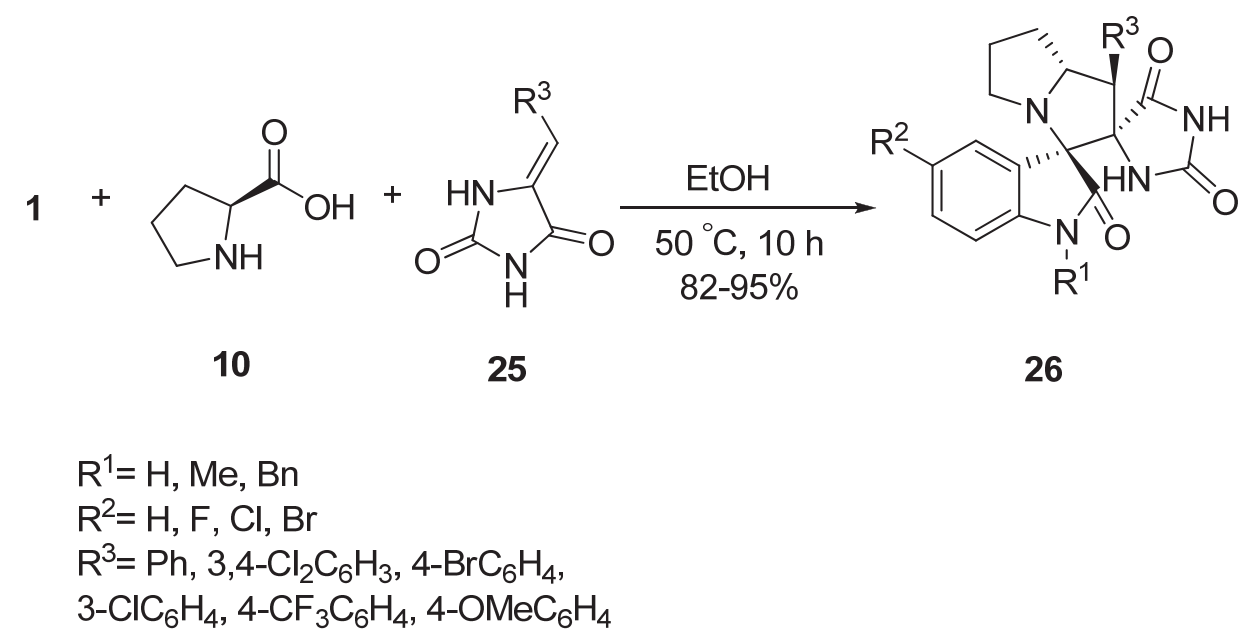

\section{Scheme 8}

Novel spirooxindole-pyrrolidine compounds $\mathbf{2 8}$ have been synthesized through 1,3-dipolar cycloaddition of azomethine ylides generated from isatin $\mathbf{1}$ and sarcosine $\mathbf{9}$ with the dipolarophile 3-(1H-imidazol-2-yl)-2-(1H-indole-3-carbonyl)acrylonitrile 27 under the optimised reaction condition (Scheme 9). ${ }^{46}$ Synthesized compounds were evaluated for their anticancer activity against A549 human lung adenocarcinoma cancer cell line.

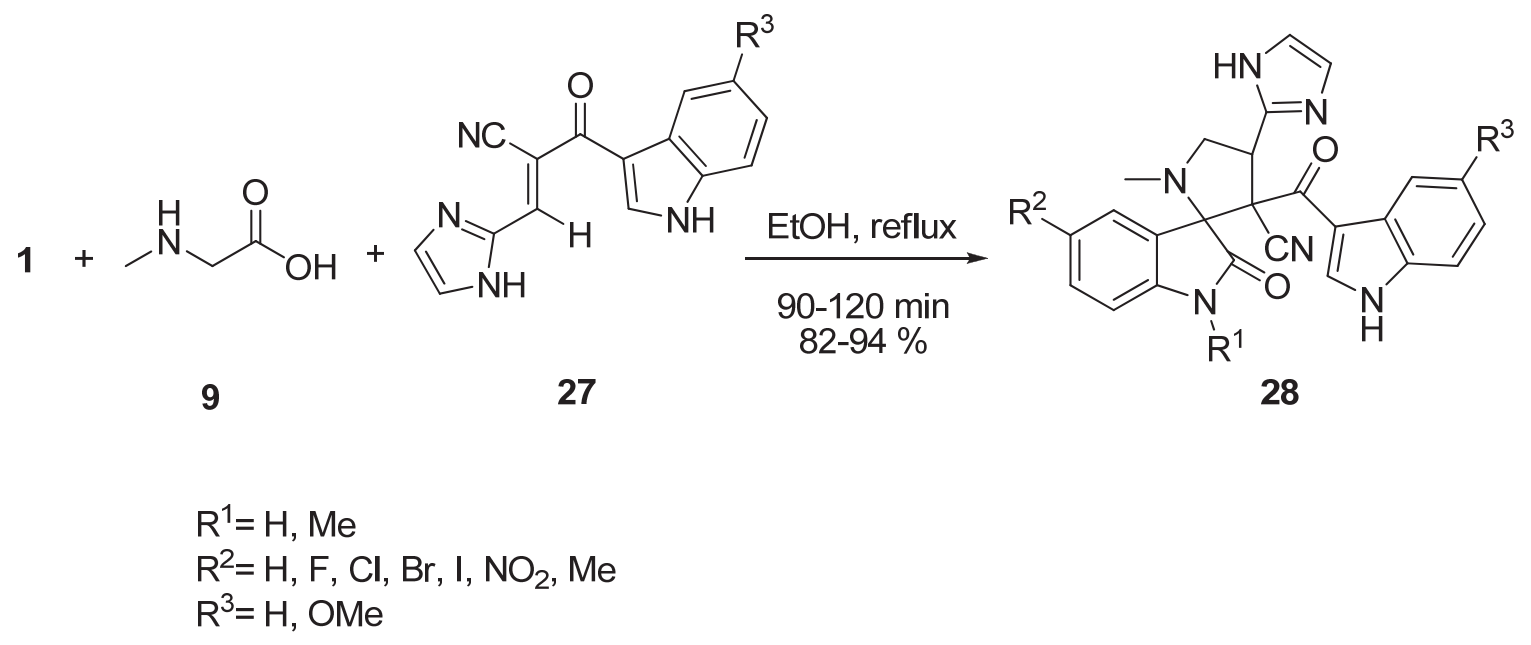

\section{Scheme 9}

$\mathrm{CuI}$ facilitated three component reaction of isatins 1, L-proline 10, and terminal alkynes containing ester or amide substituents $\mathbf{2 9}$ in acetonitrile to prepare the spiropyrrolidine oxindoles 30 (Scheme 10). ${ }^{47}$ 


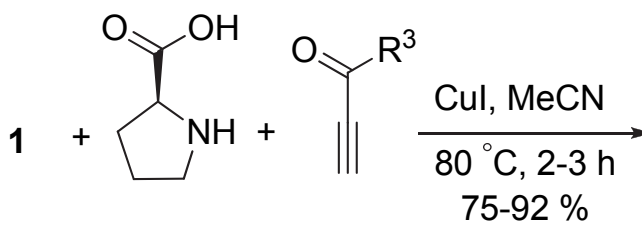

10<smiles></smiles>

30

$$
\begin{aligned}
& \mathrm{R}^{1}=\mathrm{H}, 5-\mathrm{Br}, 5,7-\left(\mathrm{NO}_{2}\right)_{2}, 5-\mathrm{F} \\
& \mathrm{R}^{2}=\mathrm{H}, \mathrm{CH}_{2} \mathrm{C}_{6} \mathrm{H}_{4} \mathrm{Cl}-m \\
& \mathrm{R}^{3}=\mathrm{NH}_{2}, \mathrm{NHMe}, \mathrm{NHEt}, \mathrm{OEt}
\end{aligned}
$$

\section{Scheme 10}

The three-component reaction of $\alpha$-amino acids such as L-proline or thiazolidine-4carboxylic acid 31, isatins $\mathbf{1}$, and acetylenedicarboxylates 32 proceeded with normal 1,3-dipolar cycloaddition reaction of azomethine ylide to give spiro[indoline-3,3'-pyrrolizines] 33. More importantly, the reaction of $\alpha$-amino acid 31, and isatins $\mathbf{1}$ with two molecular acetylenedicarboxylates 32 in methanol afforded unprecedented spiro[indoline-3,7'-pyrrolo[1,2a]-azepines] 34 as main products (Scheme 11). ${ }^{48}$<smiles>[R2]OC(=O)C#CC([R20])=O</smiles>

31<smiles>COC(=O)C#C[C+]=C(OC)OC</smiles>

31
32

32<smiles></smiles>

33<smiles>[X]CCC1C(C)=C(C(=O)OC)C2(C(=O)N([R])c3ccc([R4])cc32)C(C(=O)OC)=C1C(=O)OC[R]</smiles>

34

$\mathrm{R}^{1}=\mathrm{H}, \mathrm{Me}, \mathrm{F}, \mathrm{Cl}$

$\mathrm{R}^{2}=\mathrm{H}, \mathrm{Bn}, n-\mathrm{C}_{4} \mathrm{H}_{9}$

$\mathrm{R}^{3}=\mathrm{Me}, \mathrm{Et}$

$\mathrm{X}=\mathrm{CH}_{2}, \mathrm{CH}(\mathrm{OH}), \mathrm{S}$

\section{Scheme 11}


Catalytic asymmetric cycloaddition of isatins $\mathbf{1}$, terminal alkynes $\mathbf{3 6}$, and diethyl 2-aminomalonate 35 using the binaphthol derived phosphoric acid as catalyst afforded spiro[indoline$3,2^{\prime}$-pyrroles] 37 with quaternary stereogenic centers in high yields and excellent enantioselectivities (up to $99 \%$ yield, $>99 \%$ ee) (Scheme 12). ${ }^{49}$ According to possible reaction pathway and transition states, the 1,3-dipolar cycloadditions of alkynes with isatin-derived azomethine ylides might proceed via a sequential Michael addition and Mannich-type cyclization rather than a concerted pathway. By forming two hydrogen bonds with the substrates, the catalyst served as a Brønsted acid/Lewis base bifunctional catalyst to simultaneously activate both alkynes and isatin-derived azomethine ylides.
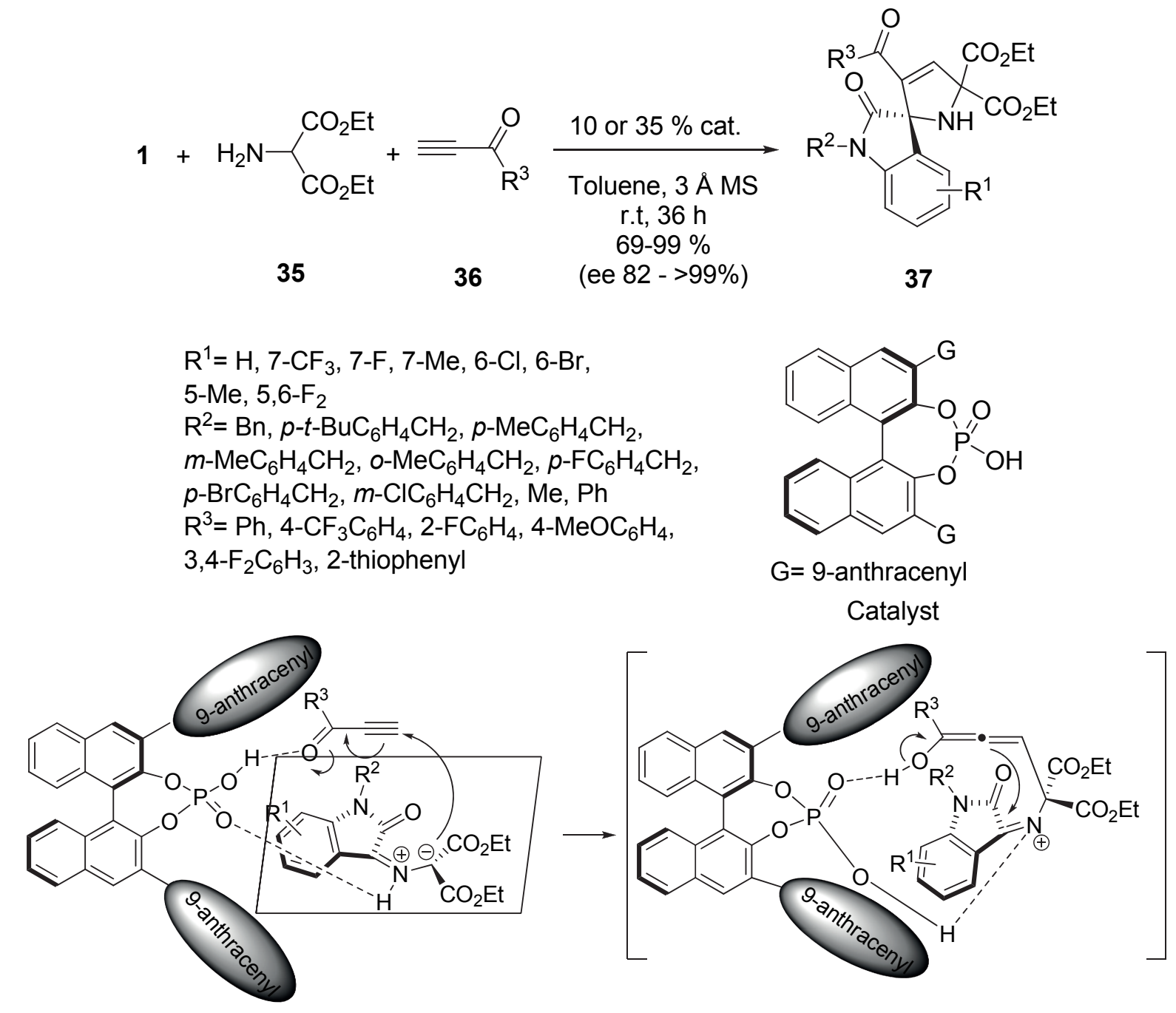

\section{Scheme 12}

The construction of a spirooxindole-based 2,5-dihydropyrrole scaffold $\mathbf{3 8}$ has been also established by the same group via the reaction of isatins $\mathbf{1}$, diethyl 2-aminomalonate $\mathbf{3 5}$ and alkynes 32 (Scheme 13). ${ }^{50}$ The authors proposed a possible pathway and transition state of the 
reaction based on the condensation of isatins and diethyl 2-aminomalonate in the presence of trifluoroacetic acid. The corresponding azomethine ylides then participated in 1,3-dipolar cycloadditions with alkynes to afford related products via a sequential Michael addition and Mannich-type cyclization. This reaction was also developed using chiral phosphoric acids as catalysts. 51

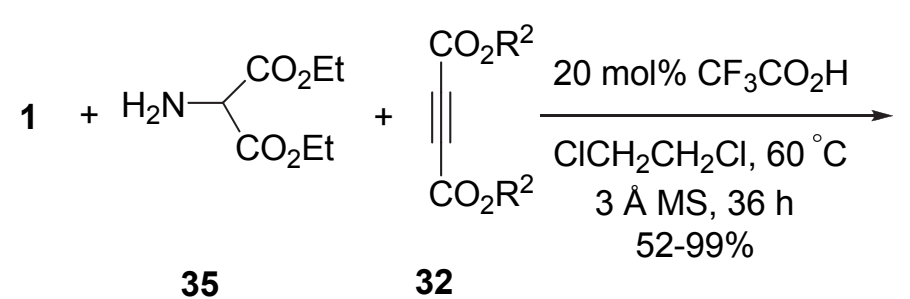

35
32

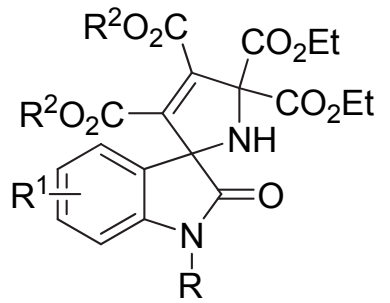

38

$$
\begin{aligned}
& \mathrm{R}=\mathrm{H}, \mathrm{Me}, i-\mathrm{Pr}, \text { Cyclopentyl, } \mathrm{Ph}, \mathrm{Bn}, 1-\text { naphtyl- } \mathrm{CH}_{2} \\
& \mathrm{R}^{1}=\mathrm{H}, 4-\mathrm{Cl}, 5-\mathrm{Br}, 5-\mathrm{Me}, 5-\mathrm{OMe}, 5-\mathrm{Cl},
\end{aligned}
$$$$
5-\mathrm{F}, 6-\mathrm{Br}, 7-\mathrm{Br}, 7-\mathrm{CF}_{3}, 5,6-\mathrm{F}_{2}
$$$$
\mathrm{R}^{2}=\mathrm{Me}, \mathrm{Et}
$$

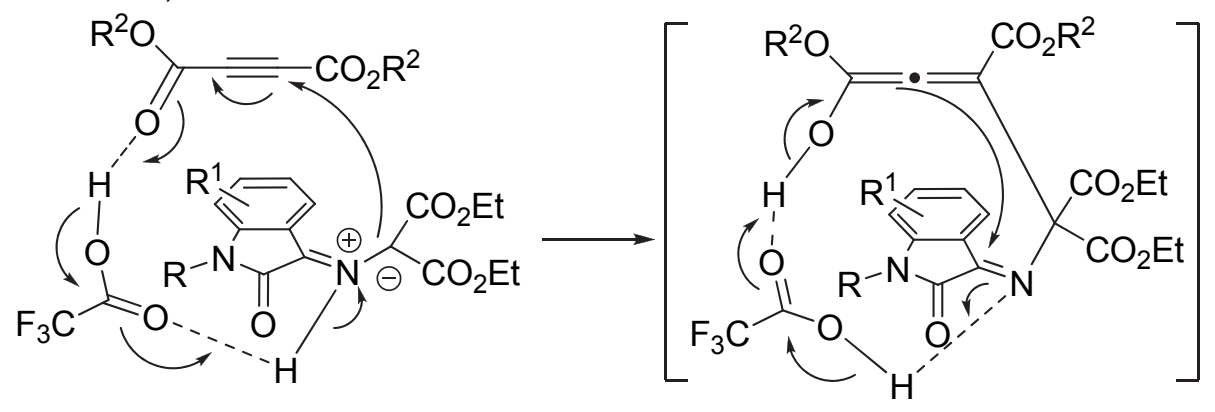

\section{Scheme 13}

The first catalytic enantioselective construction of a 3,3'-pyrrolidinyldispirooxindole scaffold 40 has been established via organocatalytic asymmetric 1,3-dipolar cycloadditions of isatin-derived azomethine ylides with methylene indolinones 39, which afforded structurally complex bis-spirooxindoles (Scheme 14). ${ }^{52}$

In a related study, Shi and co-workers established the first catalytic asymmetric 1,3-dipolar cycloadditions of isatin-derived azomethine ylide with allenes $\mathbf{4 1}$, which efficiently assembly isatins, amino-esters and 2,3-allenoate into enantioenriched spiro[indoline-3,2'-pyrrole] derivatives $\mathbf{4 2}$ with a quaternary stereogenic center in generally excellent enantioselectivities $\left(80 \%-98 \%\right.$ ee) $\left(\right.$ Scheme 15). ${ }^{53}$ 


$$
\begin{aligned}
& 1+\mathrm{H}_{2} \mathrm{~N}-\mathrm{CO}_{\mathrm{CO}_{2} \mathrm{Et}}^{\mathrm{CO}_{2} \mathrm{Et}}+ \\
& 35
\end{aligned}
$$

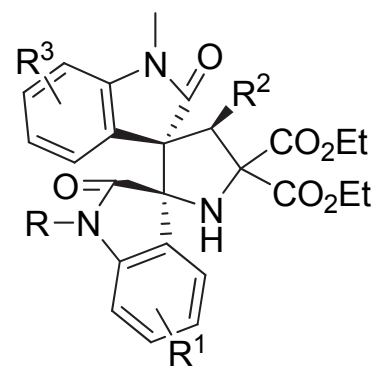

$62-99 \%$

(ee $82-98 \%$ )<smiles></smiles>

Bis-phosphoric acid (Bis-PA)

\section{Scheme 14}

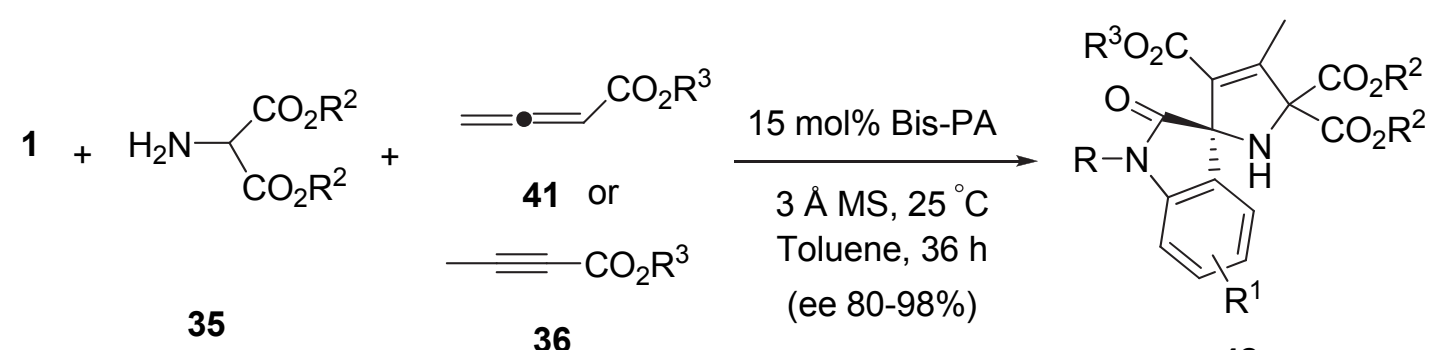

$\mathrm{R}=\mathrm{Bn}, p-\mathrm{BuC}_{6} \mathrm{H}_{4} \mathrm{CH}_{2}, p-\mathrm{BrC}_{6} \mathrm{H}_{4} \mathrm{CH}_{2}$, $m-\mathrm{MeC}_{6} \mathrm{H}_{4} \mathrm{CH}_{2}, o-\mathrm{MeC}_{6} \mathrm{H}_{4} \mathrm{CH}_{2}, p-\mathrm{MeC}_{6} \mathrm{H}_{4} \mathrm{CH}_{2}$, $m-\mathrm{ClC}_{6} \mathrm{H}_{4} \mathrm{CH}_{2}, \mathrm{O}-\mathrm{ClC}_{6} \mathrm{H}_{4} \mathrm{CH}_{2}, \mathrm{Ph}, \mathrm{Bn}$ $\mathrm{R}^{1}=\mathrm{H}, 5-\mathrm{Me}, 5,6-\mathrm{F}_{2}, 6-\mathrm{Br}, 6-\mathrm{Cl}, 7-\mathrm{Me}, 7-\mathrm{F}$, $7-\mathrm{CF}_{3}$

$\mathrm{R}^{2}=\mathrm{Me}, \mathrm{Et}$

$\mathrm{R}^{3}=\mathrm{CH}_{2}$-9-anthracenyl<smiles>O=P(O)(O)Oc1ccc2ccccc2c1-c1c(OP(=O)(O)O)c(COCc2cc3ccccc3c(-c3cccc4ccccc34)c2OP(=O)(O)O)cc2ccccc12</smiles>

Bis-phosphoric acid (Bis-PA)

\section{Scheme 15}

1,3-Dipolar cycloaddition reaction between isatin $\mathbf{1}$ and $L$-thioproline 31/ sarcosine 9 with the dipolarophile 5-benzylidene-1,3-dimethylpyrimidine-2,4,6-trione $\mathbf{4 3}$ was carried out and a series of novel dispirooxindoles $\mathbf{4 4 - 4 5}$ were synthesized (Scheme 16). ${ }^{54}$ 


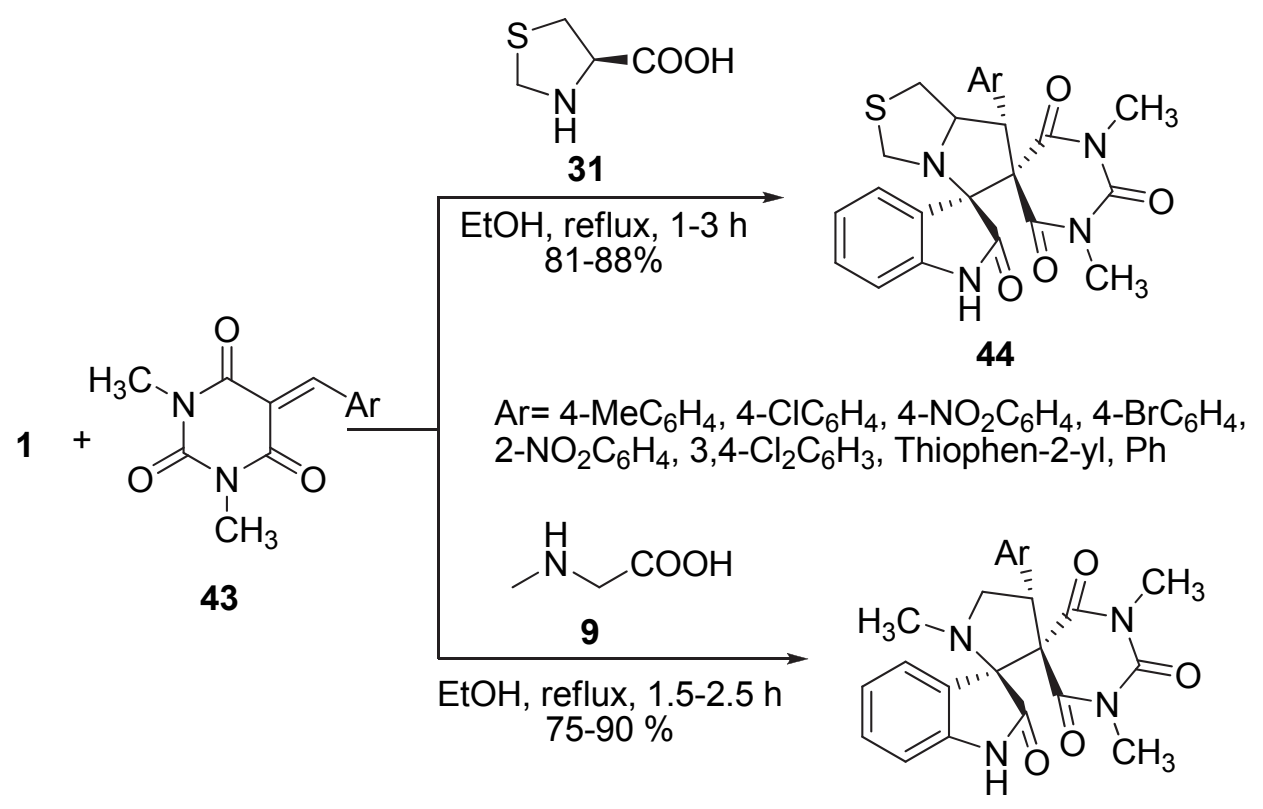

45

$\mathrm{Ar}=4-\mathrm{MeC}_{6} \mathrm{H}_{4}, 4-\mathrm{ClC}_{6} \mathrm{H}_{4}, 4-\mathrm{NO}_{2} \mathrm{C}_{6} \mathrm{H}_{4}, 4-\mathrm{BrC}_{6} \mathrm{H}_{4}$

\section{Scheme 16}

Barman et al. described the azomethine cycloaddition reactions to synthesize bispiropyrrolidines containing oxindoles 47 using sarcosine 9, isatin 1, and sugar-derived exocyclic olefin 46 and the sugar-derived olefin precursor (Scheme 17). ${ }^{55}$

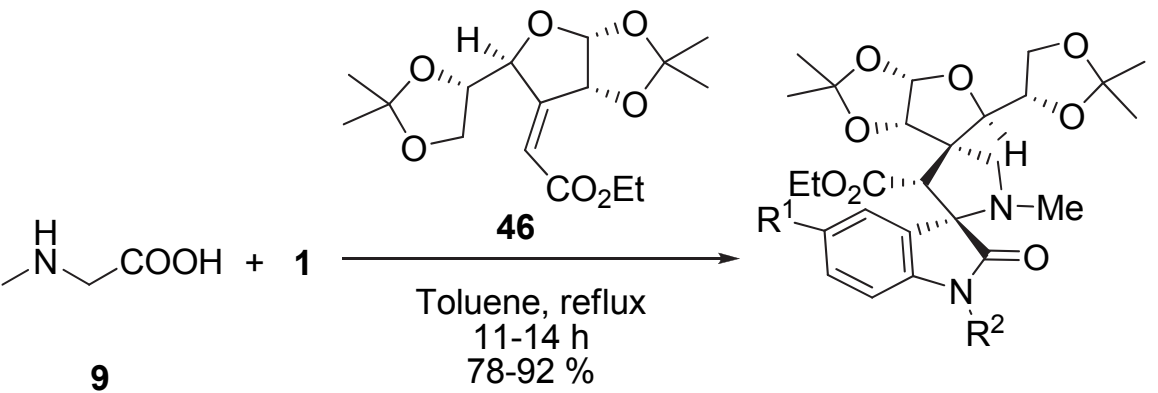

47

$$
\begin{aligned}
& R^{1}=H, F, O M e \\
& R^{2}=H, P h
\end{aligned}
$$

\section{Scheme 17}

Dispiro[3H-indole-3,2'-pyrrolidine-3',3"'-piperidine]-2(1H),4"-dione derivatives 49 were synthesized by the reaction of substituted isatins 1, sarcosine 9, and 1-methyl-3,5-bis $[(E)$ arylidene]piperidin-4-ones 48 with high degree of chemo-, regio- and stereoselectivity (Scheme 18). ${ }^{56}$ The regioselectivity in the product formation can be explained by considering the 
secondary orbital interaction (SOI) of the orbital of the carbonyl group of dipolarophile $\mathbf{4 8}$ with those of the ylide as shown in Scheme 18.

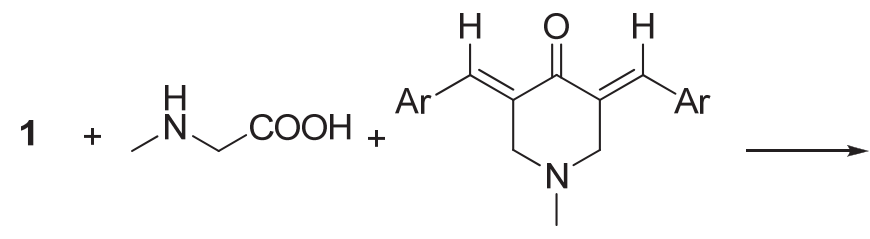

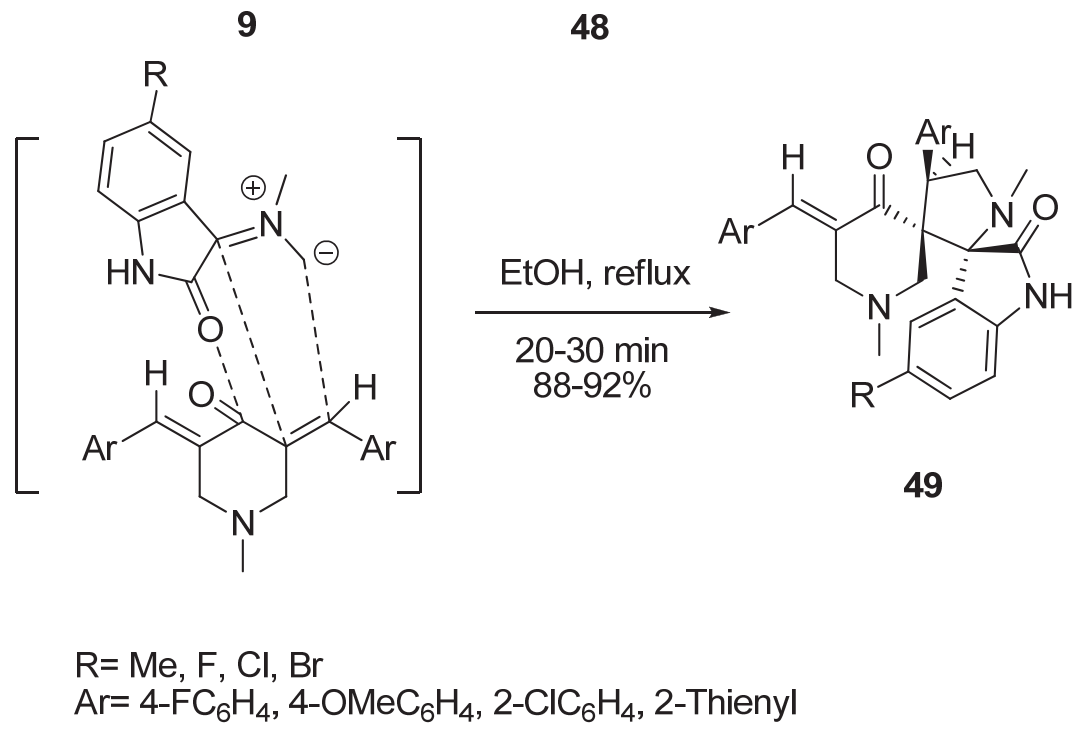

\section{Scheme 18}

A series of piperidone-grafted novel mono-spiropyrrolizines $\mathbf{5 1}$ has been synthesized by the [3+2]-cycloaddition reactions of 1-acryloyl-3,5-bisbenzylidenepiperidin-4-ones $\mathbf{5 0}$, isatin $\mathbf{1}$, and $L$-proline 10 (Scheme 19). ${ }^{57}$ The in vitro evaluation of cholinesterase enzymes inhibitory activity of these cycloadducts was performed. Application of sarcosine ${ }^{58}$ and phenylglycine ${ }^{59}$ in this reaction was also investigated by the same group.

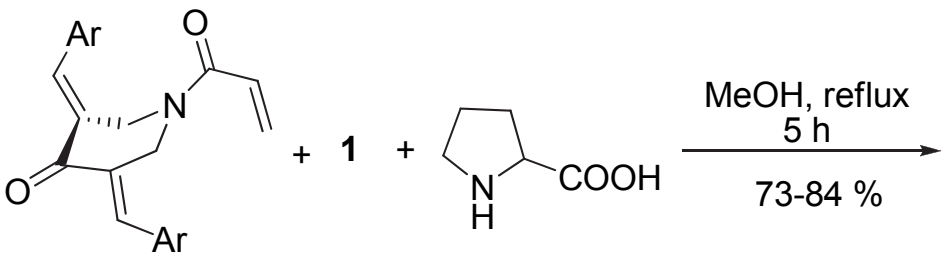
50

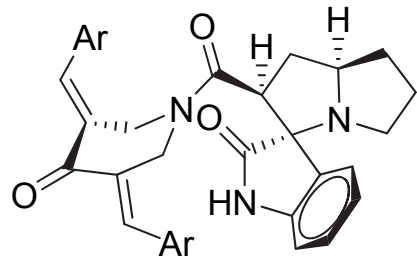

51

$\mathrm{Ar}=\mathrm{Ph}, 2-\mathrm{MeC}_{6} \mathrm{H}_{4}, 2-\mathrm{OMeC}_{6} \mathrm{H}_{4}, 2-\mathrm{ClC}_{6} \mathrm{H}_{4}$, 2- $\mathrm{FC}_{6} \mathrm{H}_{4}, 3-\mathrm{NO}_{2} \mathrm{C}_{6} \mathrm{H}_{4}, 4-\mathrm{MeC}_{6} \mathrm{H}_{4}, 4-\mathrm{ClC}_{6} \mathrm{H}_{4}$, 4- $\mathrm{FC}_{6} \mathrm{H}_{4}$, 1-Naphthyl, 2,4- $\mathrm{Cl}_{2} \mathrm{C}_{6} \mathrm{H}_{3}$

\section{Scheme 19}


The 1,3-dipolar cycloaddition reaction of azomethine ylide generated in situ from isatin $\mathbf{1}$ and sarcosine 9 to 5-arylmethylene-6,7-dihydro-1-benzothiophen-4(5H)-ones 52 gave novel 1'methyl-4'-aryl-6,7-dihydro-4H-dispiro[1-benzothiophene-5,3'-pyrrolidine-2',3'"-indole]-2",4$\left(1^{\prime \prime} H\right)$-diones 53 in moderate yields (Scheme 20). ${ }^{60}$<smiles>O=C1/C(=C/[18F])CCc2sccc21</smiles>

52<smiles>CNCC(=O)O</smiles>

9<smiles>CN1CC[C@@]2(C(=O)Nc3ccccc32)[C@@]12CCc1sccc1C2=O</smiles>

53

$$
\begin{aligned}
& \mathrm{Ar}=\mathrm{C}_{6} \mathrm{H}_{5}, 4-\mathrm{FC}_{6} \mathrm{H}_{4}, 4-\mathrm{ClC}_{6} \mathrm{H}_{4}, 4-\mathrm{MeC}_{6} \mathrm{H}_{4}, \\
& \text { 4-MeOC } 6 \mathrm{H}_{4}, 3,4,5-(\mathrm{OMe})_{3} \mathrm{C}_{6} \mathrm{H}_{2}
\end{aligned}
$$

\section{Scheme 20}

A series of novel spiro[indoline-3,2'-pyrrolidine] derivatives containing cyano group 55 were synthesized via a cycloaddition reaction of isatin $\mathbf{1}$, sarcosine 9, and Knoevenagel adducts 54 in refluxing aqueous methanol (Scheme 21). ${ }^{61}$

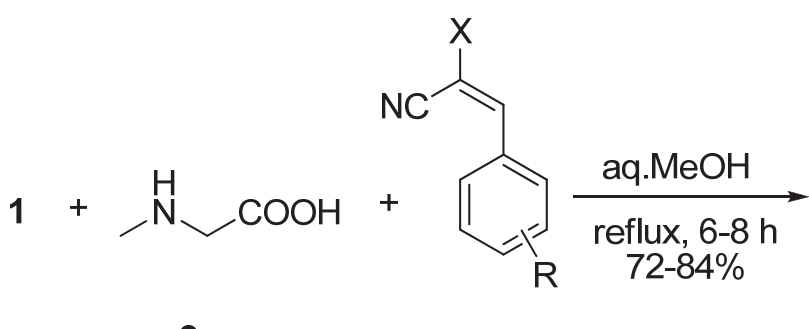

9
54<smiles>[R]c1ccccc1[C@H]1CN(C)[C@]2(C(=O)Nc3ccccc32)[C@H]1C#N</smiles>

55

$\mathrm{R}=\mathrm{H}$, 4-Me, 4-OMe, 4-Cl, 4-F, 3,4,5-tri- $\mathrm{OCH}_{3}, 3,4$-di-Cl $\mathrm{X}=\mathrm{CO}_{2} \mathrm{Me}, \mathrm{CO}_{2} \mathrm{Et}$

\section{Scheme 21}

Perumal and co-workers prepared novel dispirooxindole-pyrrolidine derivatives $\mathbf{5 7}$ by 1,3dipolar cycloaddition of isatins 1 and sarcosine 9 with the dipolarophile 3-(1H-indol-3-yl)-3-oxo2-(2-oxoindolin-3-ylidene)propanenitrile 56 (Scheme 22). ${ }^{62}$ Synthesized compounds were evaluated for their antimicrobial activity and all the compounds showed significant activity. 
Anticancer activity was also evaluated against A549 human lung adenocarcinoma cancer cell lines. In another study, the same authors conducted this reaction using 1,4-naphthoquinone 3 as dipolarophile with sarcosine 9 or L-proline for the synthesis of novel spirooxindoles $\mathbf{5 8}$ (Scheme 22). ${ }^{63}$ Ethyl lactate as an invaluable bio based solvent was also demonstrated as the medium for this 1,3-dipolar cycloaddition reaction. ${ }^{64}$

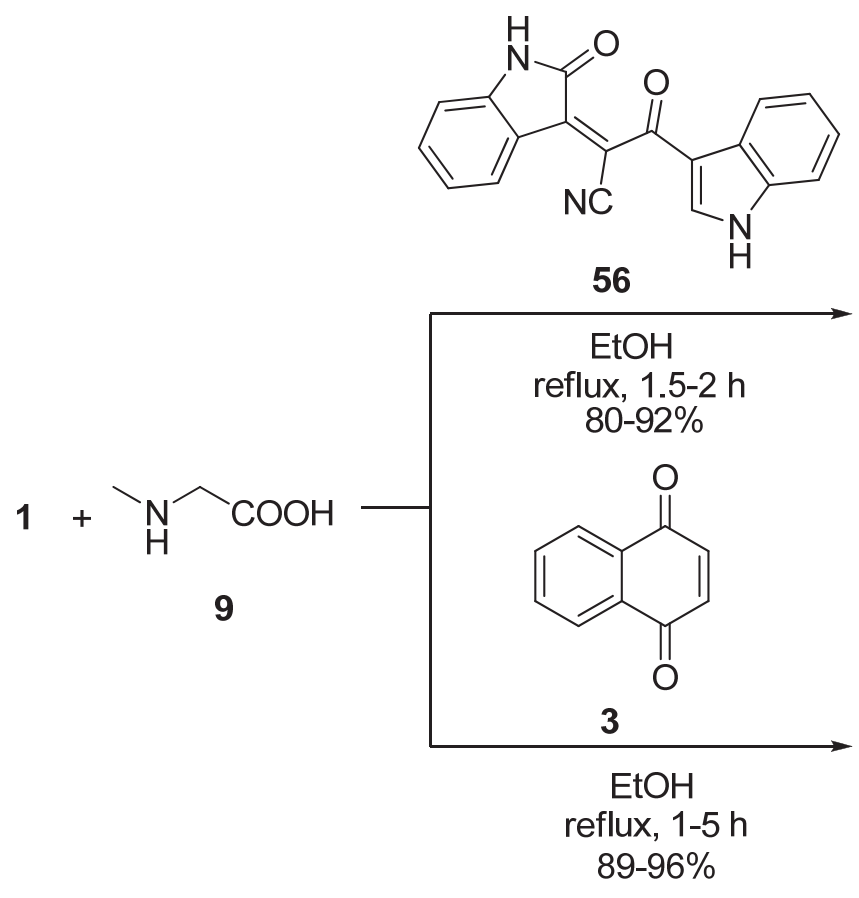

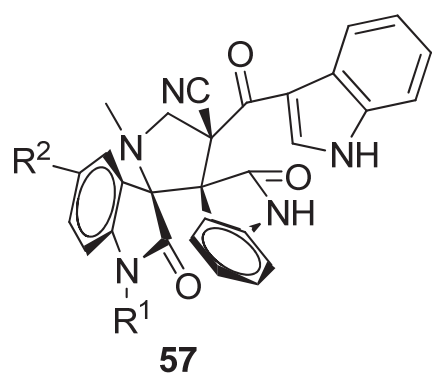

$\mathrm{R}^{1}=\mathrm{H}, \mathrm{Me}$, Et, $n$-Bu, $n$-hex, prop-1-ene, prop-1-yne, $\mathrm{Ph}, \mathrm{Bn}, \mathrm{CH}_{2} \mathrm{CO}_{2} \mathrm{Et}$ $\mathrm{R}^{2}=\mathrm{H}, \mathrm{Me}, \mathrm{NO}_{2}, \mathrm{~F}, \mathrm{Cl}, \mathrm{Br}, \mathrm{I}$<smiles>[R]c1ccc2c(c1)C1(C(=O)N2C)C(C)=C2C(=O)c3ccccc3C(=O)C21</smiles>

58

$\mathrm{R}^{1}=\mathrm{H}, \mathrm{Me}, \mathrm{Et}, n$-Bu, $n$-hex, prop-1-ene, prop-1-yne, $\mathrm{Ph}, \mathrm{Bn}, \mathrm{COMe}$ $\mathrm{R}^{2}=\mathrm{H}, \mathrm{Me}, \mathrm{Cl}, \mathrm{Br}$, I

\section{Scheme 22}

A one-pot, three-component procedure for the synthesis of novel dispiropyrrolidinebisoxindole derivatives $\mathbf{6 0}$ by cycloaddition trapping of azomethine ylides generated in situ from isatin 1 and sarcosine 9, and 3-aroylmethyleneindol-2-ones 59 has been reported in [bmim] $\mathrm{PF}_{6}$, as a recyclable solvent in excellent yield without using any catalyst (Scheme 23). ${ }^{65}$

Highly functionalized dispiropyrrolizidine derivatives 62 were synthesized via a threecomponent [3+2] cycloaddition reaction of azomethine ylides with (Z)-4-benzylidene-2phenyloxazol-5(4H)-ones 61 as dipolarophiles (Scheme 24). ${ }^{66}$ Many of these compounds were evaluated for their antiproliferative properties in vitro against cancer cells and several compounds were found to have good activities. 


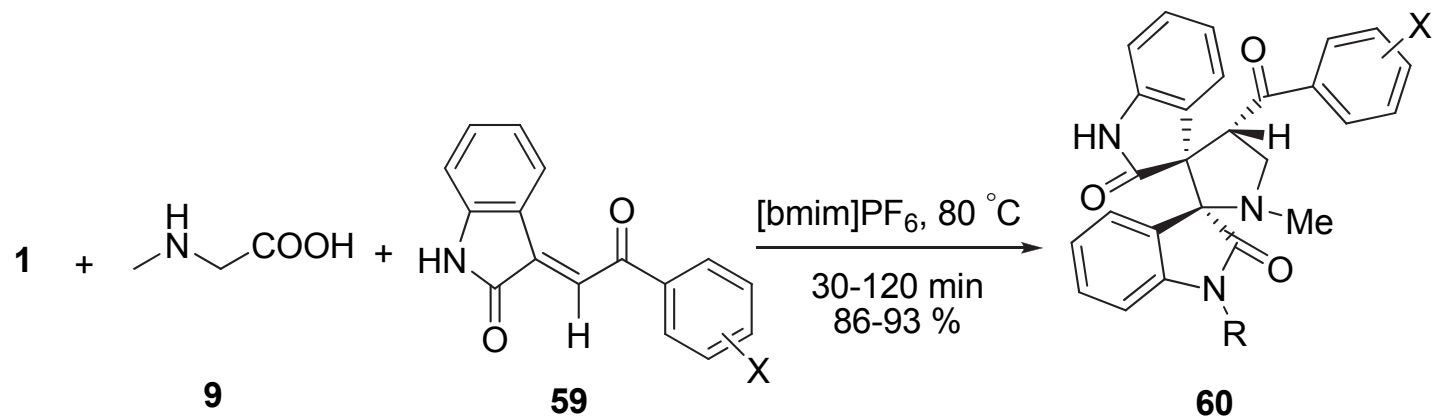

$\mathrm{R}=\mathrm{H}, \mathrm{Me}, \mathrm{Bn}$

$\mathrm{X}=\mathrm{H}, 3-\mathrm{OMe}, 4-\mathrm{F}$

\section{Scheme 23}

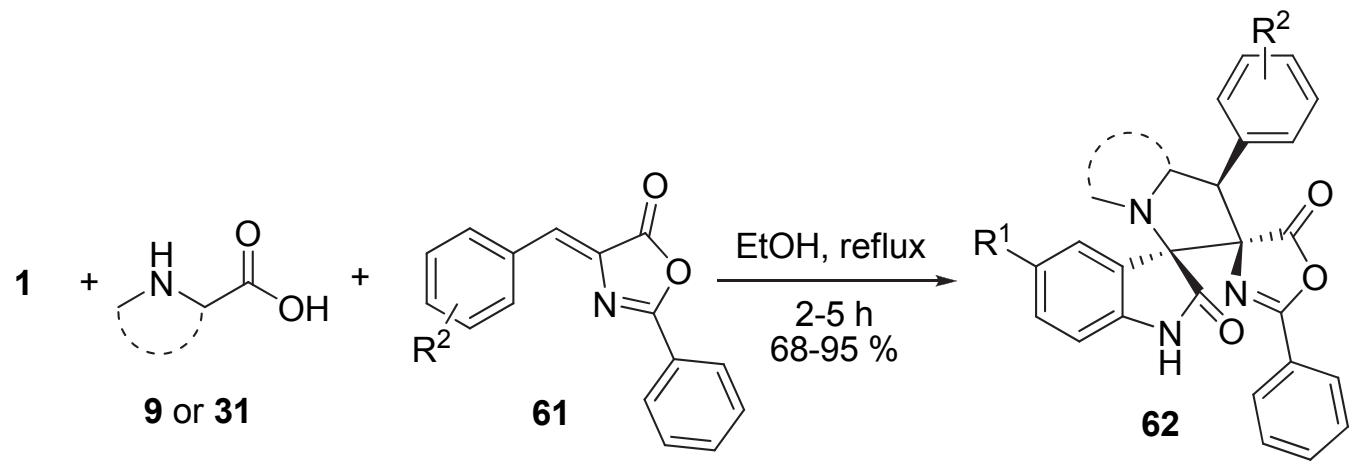

$$
\begin{aligned}
& \mathrm{R}^{1}=\mathrm{H}, \mathrm{F}, \mathrm{Cl}, \mathrm{Me} \\
& \mathrm{R}^{2}=4-\mathrm{NO}_{2}, 4-\mathrm{F}, 4-\mathrm{Cl}, 4-\mathrm{Br}, 4-\mathrm{Me}, \\
& \text { 4-OMe, 3-Cl, 3-F, 3,4-Cl }, 2-\mathrm{NO}_{2}
\end{aligned}
$$<smiles>COC(=O)CNCC(=O)O</smiles>

\section{Scheme 24}

Synthesis of naphthyl pyrrolidine/pyrrolizidine-spirooxindoles 64-65 has been achieved by a one pot three component 1,3-dipolar cycloaddition reaction. The azomethine ylides generated in situ from isatin/ $N$-substituted isatin 1 and sarcosine 9/L-proline 10 reacted with naphthylidene tetralone $\mathbf{6 3}$ as a dipolarophile to give naphthyl dispiro heterocycles (Scheme 25). ${ }^{67}$

The reaction of $(E)$-3-benzylidenechroman-2-one 66 with isatin 1 and sarcosine 9 or $L$ proline 10 synthesized the hybrid oxindole-functionalized dispiropyrrolidines and dispiropyrrolizidines 67-68. The dispiro compounds are obtained via [3+2]-cycloaddition reactions between $(E)$-3-benzylidenechroman-2-one $\mathbf{6 6}$ and the adduct generated from isatin and sarcosine or $L$-proline (Scheme 26). ${ }^{68}$ 


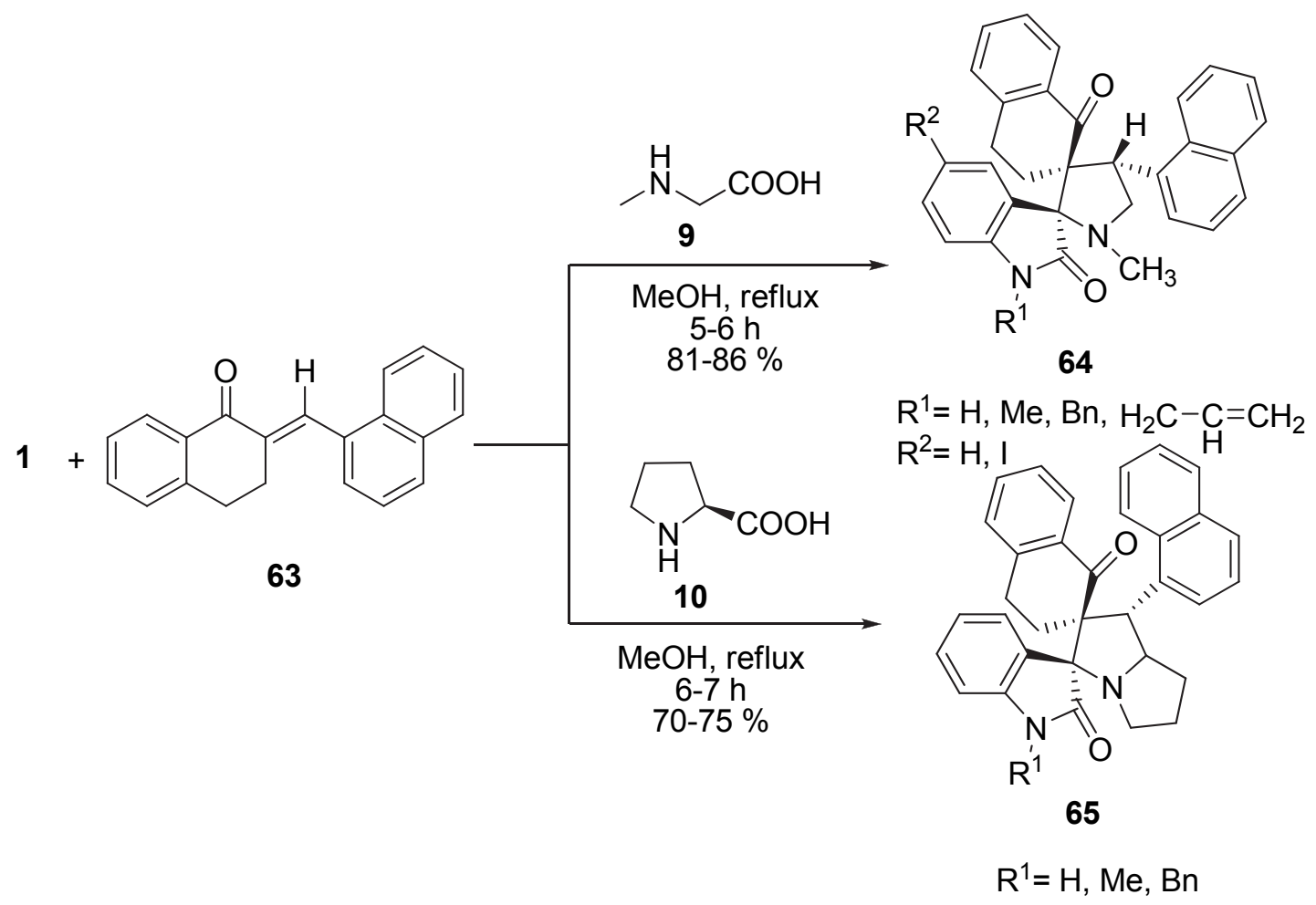

\section{Scheme 25}

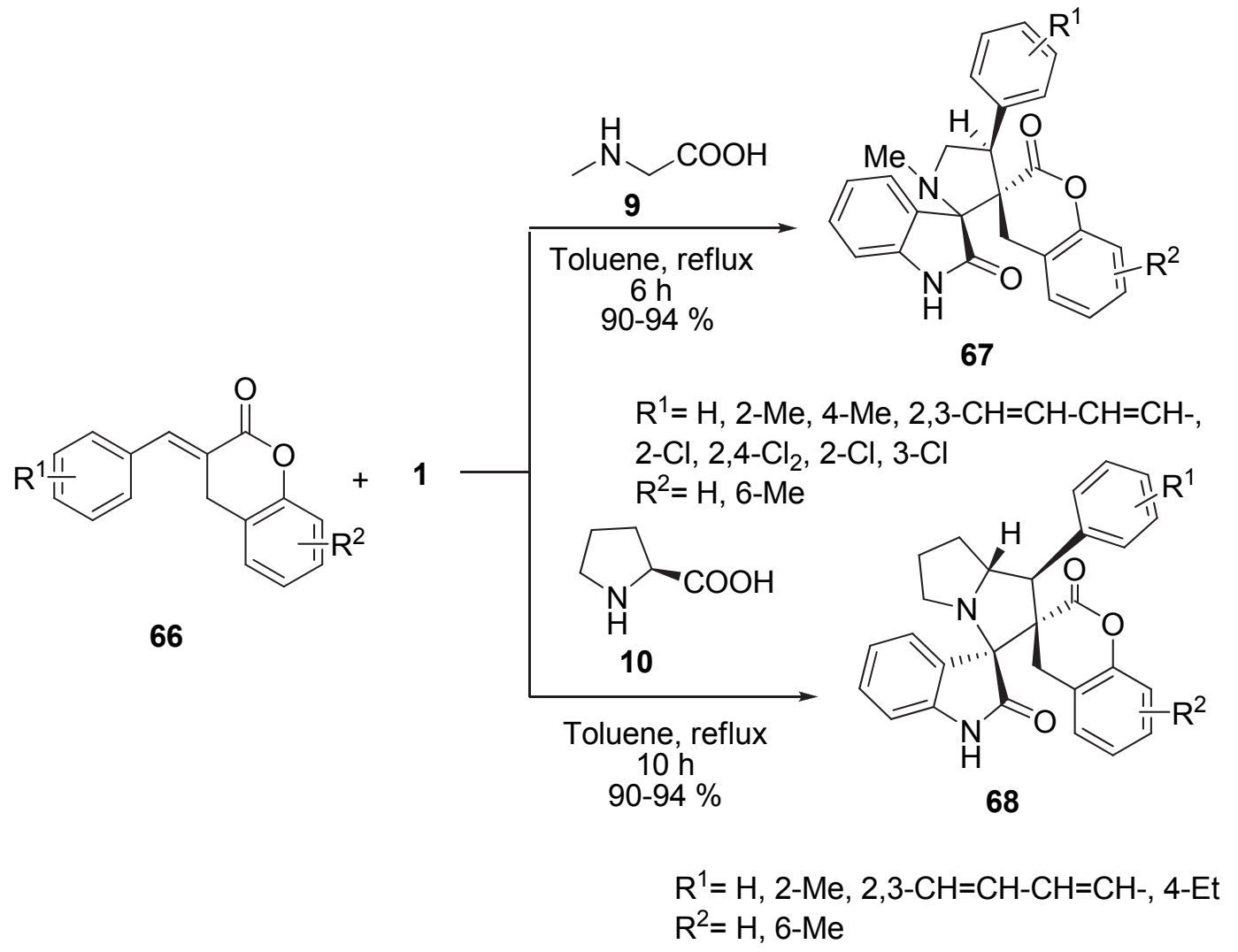

Scheme 26 
The regioselectivity of the Huisgen reaction of isatin $\mathbf{1}, \alpha$-amino acids $\mathbf{7 0},{ }^{69-70}$ and $(E)-\beta$ phenyl nitroolefins 69 was studied by Chen and co-workers (Scheme 27). Regioisomers 71a-b were produced in each reaction and the major products showed different regioselectivity compared to previously reported spirooxindole derivatives.

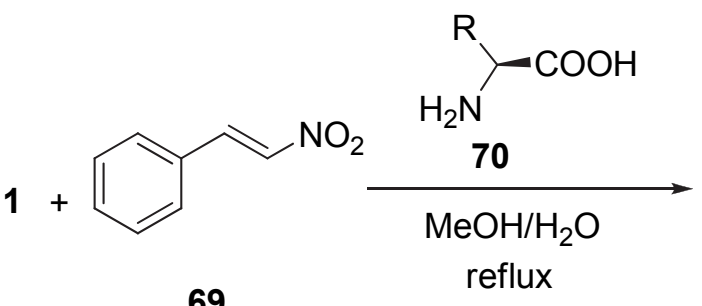

69

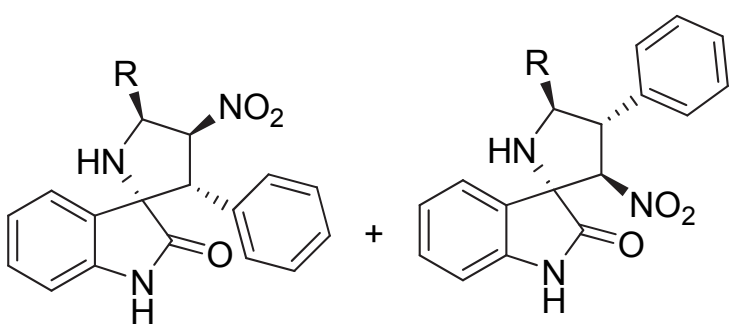

71a $\quad 52.4-66.1 \%$

71b $7.7-17.2 \%$

$$
\mathrm{R}=\mathrm{Bn}, \mathrm{CH}_{2} \mathrm{OH}, i-\mathrm{Bu}
$$

\section{Scheme 27}

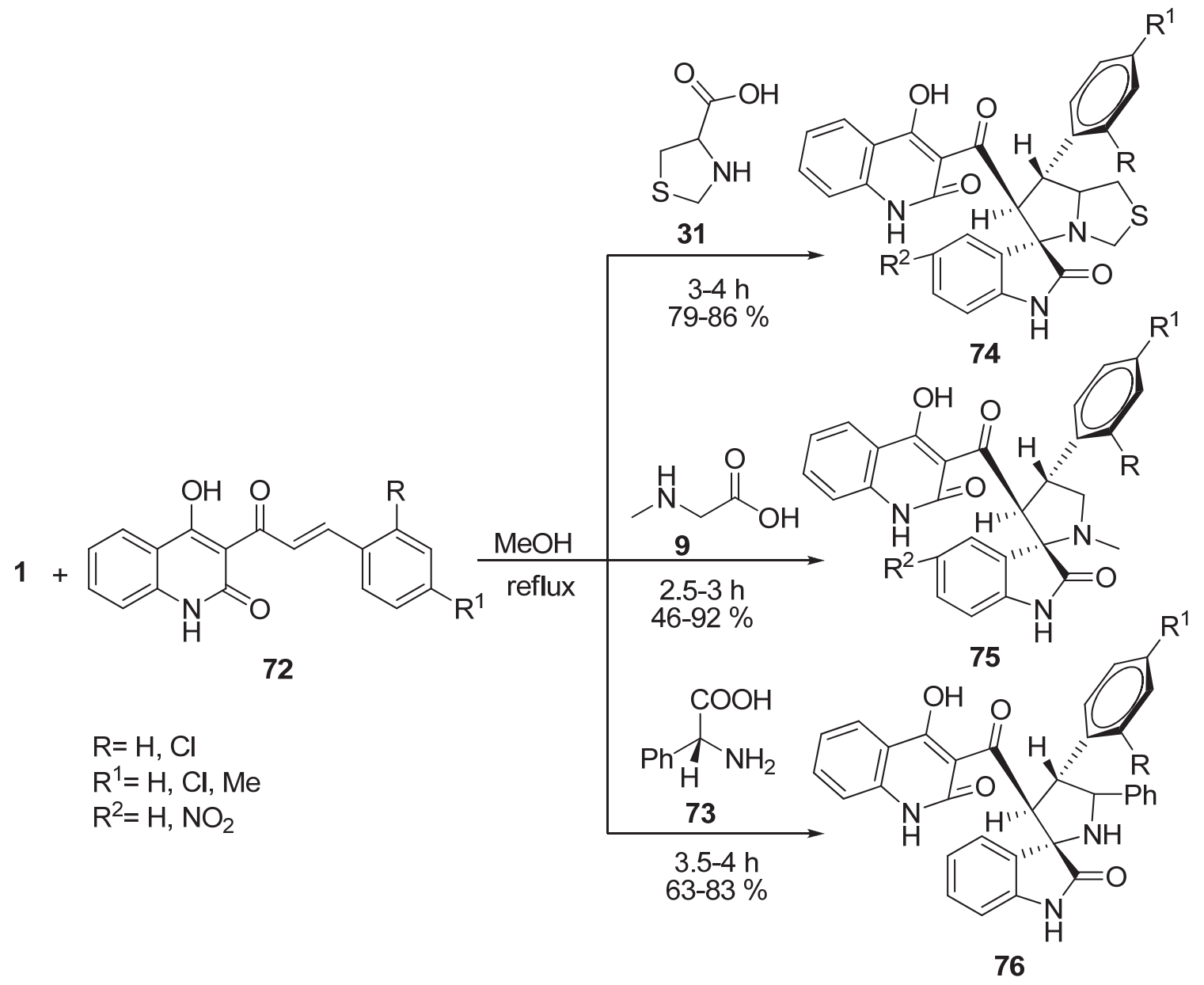

Scheme 28 
The synthesis of 4-hydroxyquinolone grafted spiropyrrolidines or pyrrolizidines 74-76 has been accomplished through 1,3-dipolar cycloaddition reaction of various azomethine ylides derived from isatin 1 and thioproline 31 /sarcosine 9 / phenylglycine $\mathbf{7 3}$ with 4-hydroxyquinolone derivatives 72 as dipolarophile (Scheme 28). ${ }^{71}$ Cytotoxicity evaluation of selected compounds showed significant inhibition of cell proliferation against cervical as well as colon cancer cell lines.

Sarrafi and co-workers presented a condensation of dimethyl 2-(aryloxy)- or 2-(alkyl- or 2arylthio)fumarate derivatives $\mathbf{7 7}$ as dipolarophiles in 1,3-dipolar cycloaddition reaction with azomethine ylides which are generated by the reaction of isatin 1 with the secondary amino acids proline $\mathbf{1 0}$ or sarcosine 9 to give novel spirooxindolopyrrolizidines/pyrrolidines $\mathbf{7 8 - 8 0}$ in high yields with excellent regioselectivities (Scheme 29). ${ }^{72}$

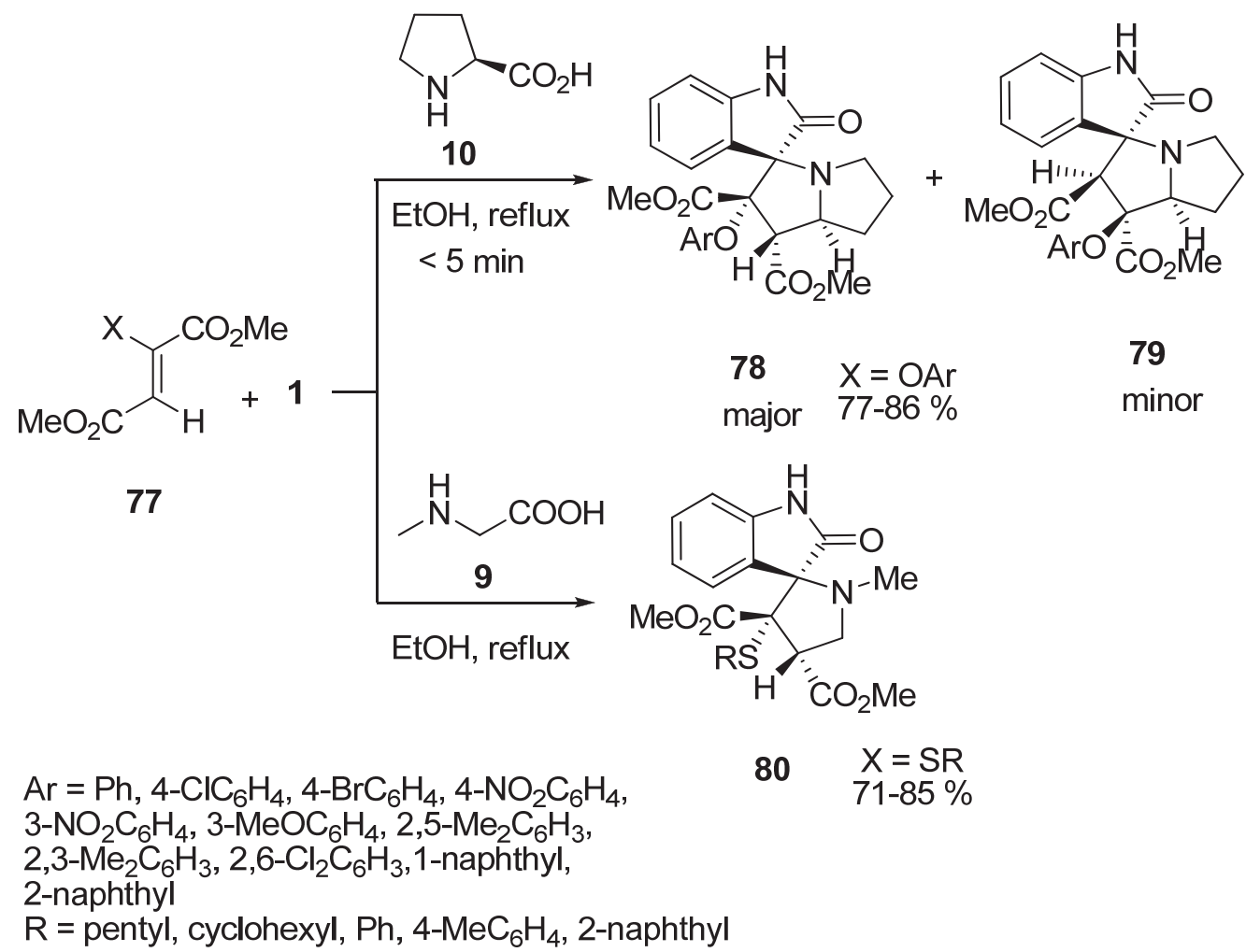

\section{Scheme 29}

The reaction of 1,2,3,4-tetrahydroisoquinoline $\mathbf{8 1}$ and isatin derivatives $\mathbf{1}$ with $\beta$ nitrostyrene and $\beta$-methyl- $\beta$-nitrostyrene 69 was investigated in a one-pot three-component process (Scheme 30). ${ }^{73}$ The reaction afforded a series of novel spiroindolizidines 82 as major products in a similar regio- and stereocontrolled manner. 


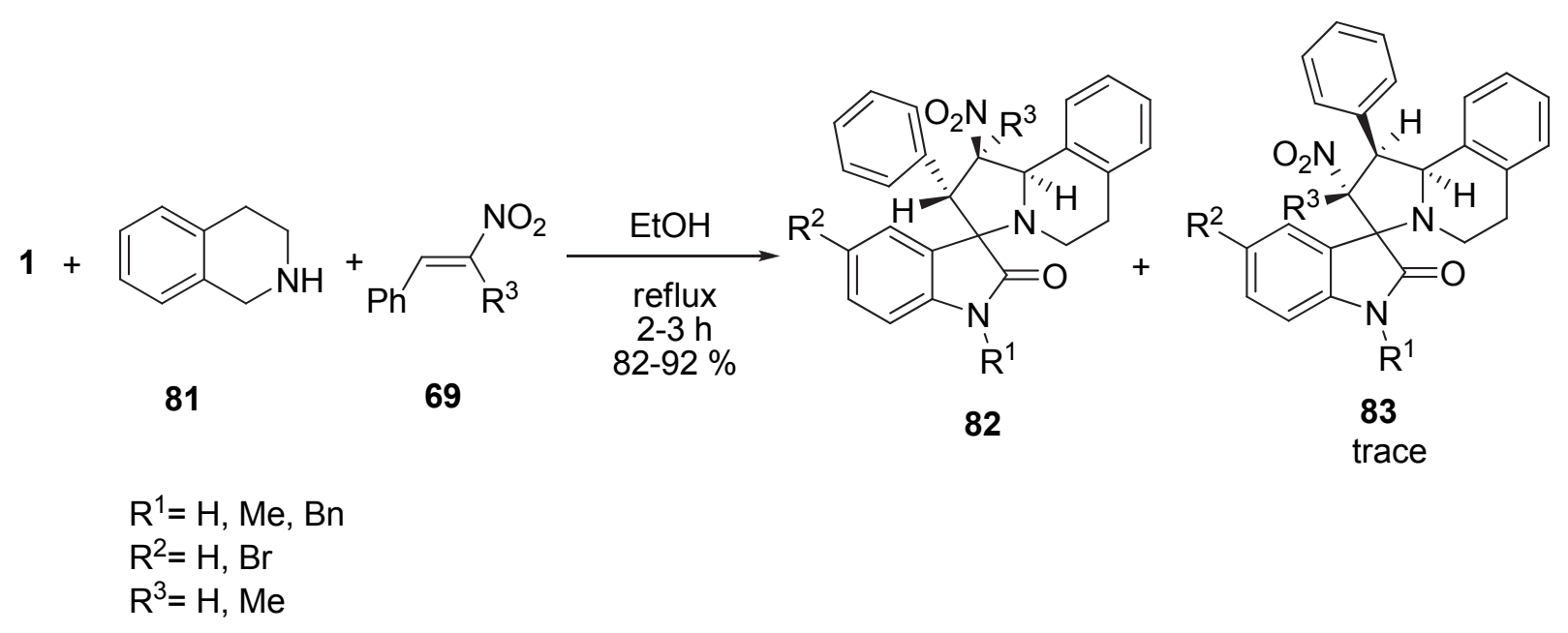

\section{Scheme 30}

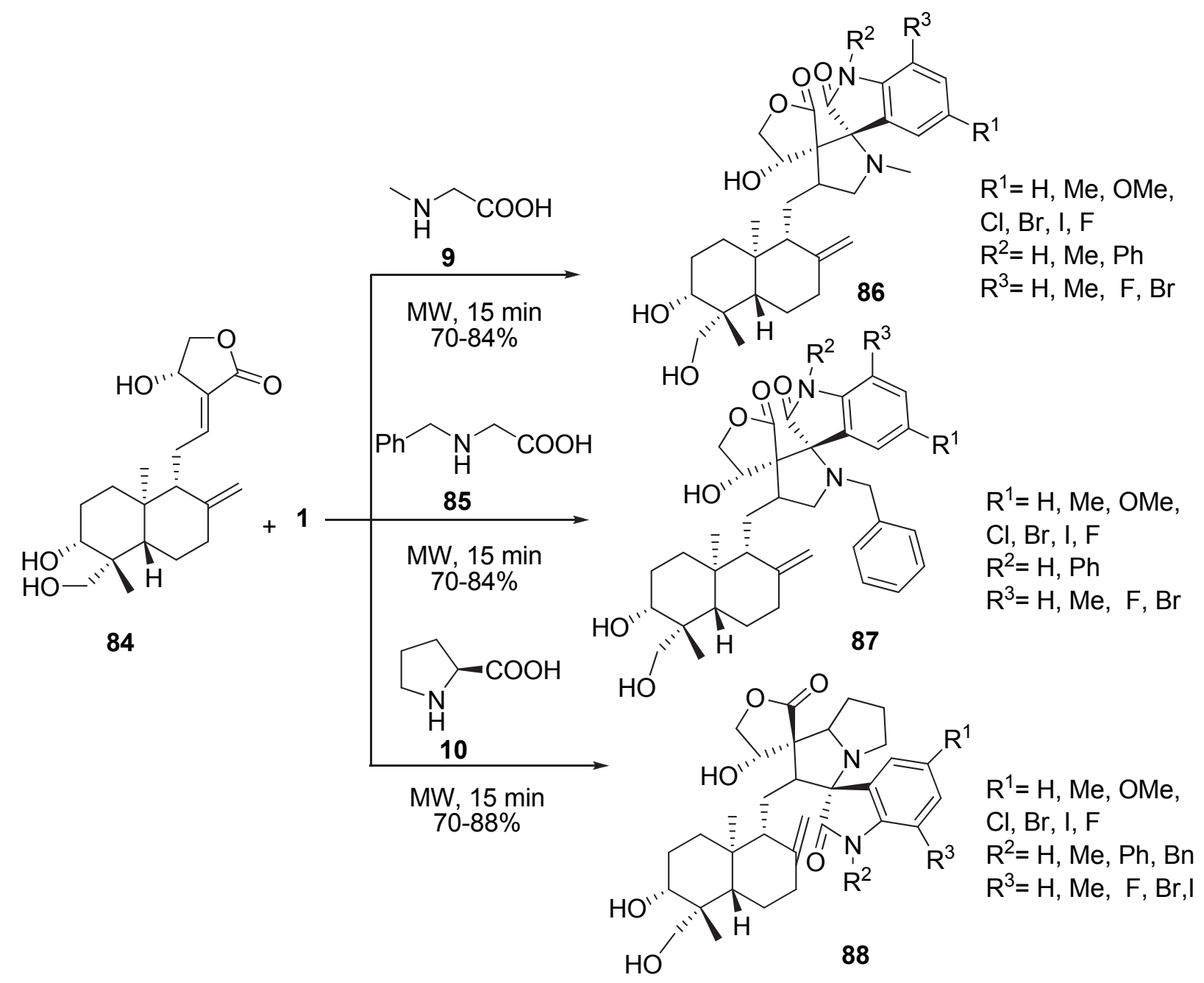

\section{Scheme 31}


Dispiro-pyrrolidino/pyrrolizidino fused oxindoles 86-88 have been derived from andrographolide $\mathbf{8 4}$ via azomethine ylide cycloaddition to the conjugated double-bond under microwave irradiation (Scheme 31). ${ }^{74}$ The reactions are chemo-, stereo-, and regioselective in nature. Change in amino acid from sarcosine 9/N-benzyl glycine $\mathbf{8 5}$ to $L$-proline $\mathbf{1 0}$ changes the regiochemistry.

$\mathrm{Wu}$ et al. studied the regiosteselective synthesis of spirooxindolo-pyrrolidines, pyrrolizidines, and pyrrolothiazole frameworks containing a furanyl moiety 90-92 via the multicomponent condensation of azomethine ylides (generated in situ from amino acids and isatin) with the Knoevenagel adduct derivatives $\mathbf{8 9}$ (preformed by the reaction of 2-acetyl furan with substituted benzaldehydes) (Scheme 32). ${ }^{75}$ Corresponding compounds were screened for their antibacterial activities.

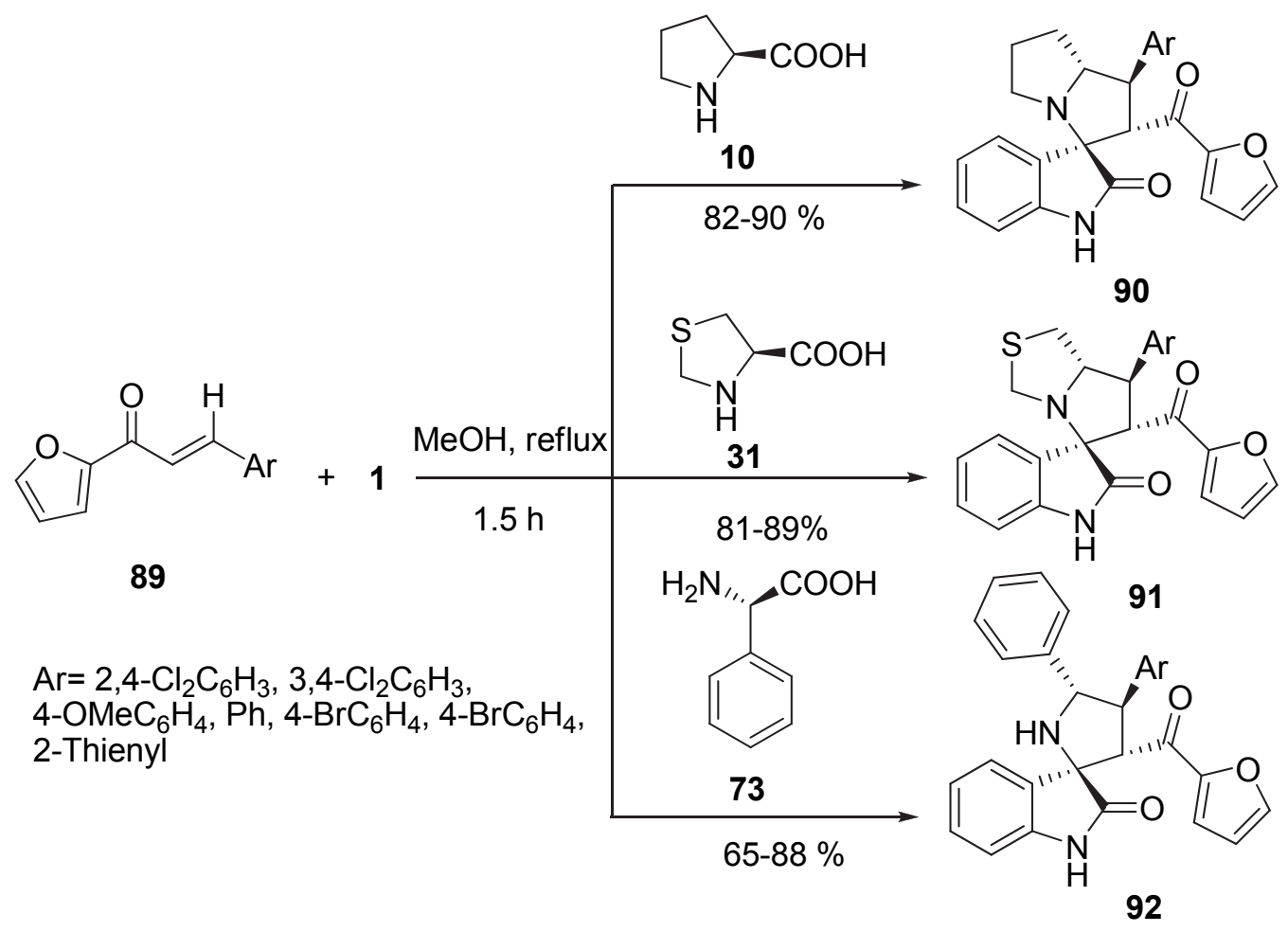

\section{Scheme 32}

The [3+2] cycloaddition of chiral dipolarophile 93 with azomethine ylide, generated from isatin 1 derivatives and $(S)$-proline 10, resulted in the formation of new chiral spirooxindolopyrrolizidine 94 which contains four contiguous stereogenic centers (Scheme 33). ${ }^{76}$ It was observed that the chiral auxiliary was removed easily with hydrogen peroxide in the presence of lithium hydroxide and cleanly produced products 95 in excellent to quantitative yields. 


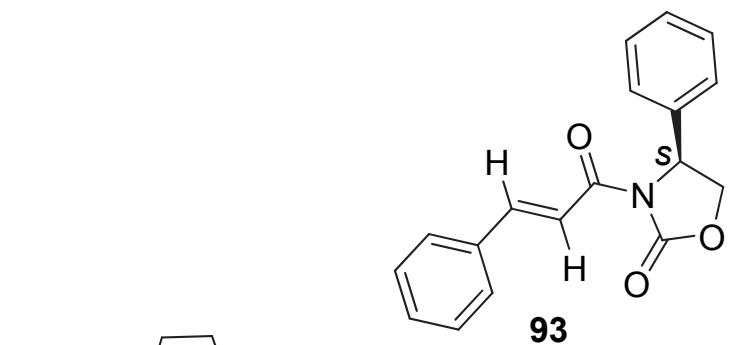

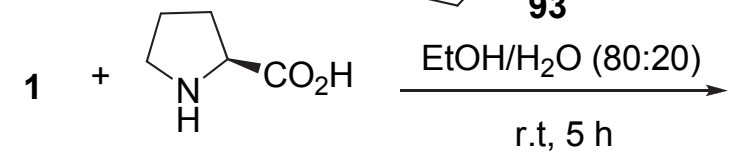

10

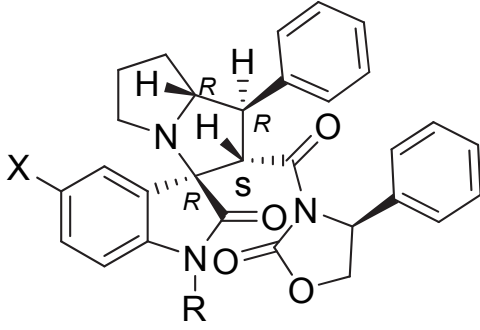

94 $88-98 \%$

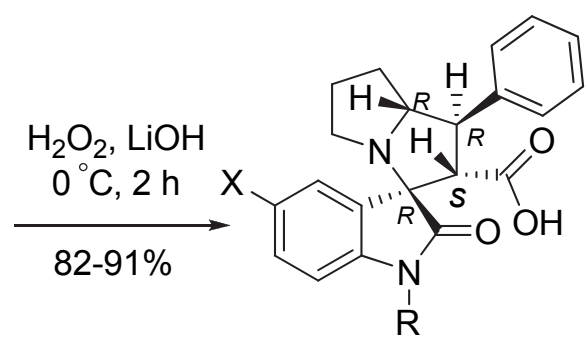

95

\section{Scheme 33}

A series of novel highly functionalized spiropyrrolidine-oxindoles 97 have been synthesized through 1,3-dipolar cycloaddition of an azomethine ylide formed from isatin $\mathbf{1}$ and various amino acids such as sarcosine, proline and thioproline 31 with the dipolarophile $(E)$-3-(1,3-diphenyl$1 H$-pyrazol-4-yl)-2-(1H-indole-3-carbonyl)acrylonitrile 96 under optimized conditions (Scheme $34){ }^{77}$<smiles>N#C/C(=C\c1cn(-c2ccccc2)nc1-c1ccccc1)C(=O)c1c[nH]c2ccccc12</smiles>

96<smiles>COC1CSC(C(=O)O)N1</smiles>

31

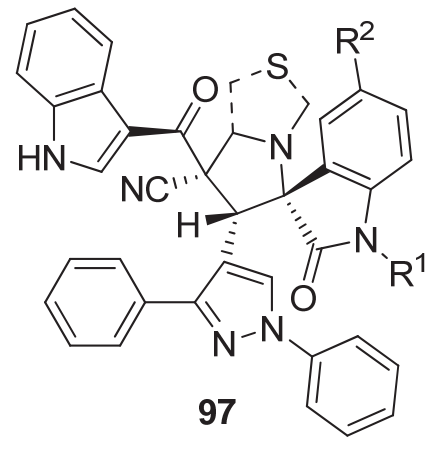

$\mathrm{R}^{1}=\mathrm{H}$, Allyl, Benzyl, $n$-Butyl, Methyl, Propargyl $\mathrm{R}^{2}=\mathrm{H}, \mathrm{Cl}, \mathrm{NO}_{2}$

\section{Scheme 34}


The synthesis of novel spirooxindolo(pyrrolizidine/pyrrolidine) ring systems $\mathbf{9 9 - 1 0 0}$ by the cycloaddition reaction of azomethine ylides generated from sarcosine 9/proline $\mathbf{1 0}$ and isatin $\mathbf{1}$ with dibenzylideneacetone 98 was described by Javidan et al. (Scheme 35). ${ }^{78}$

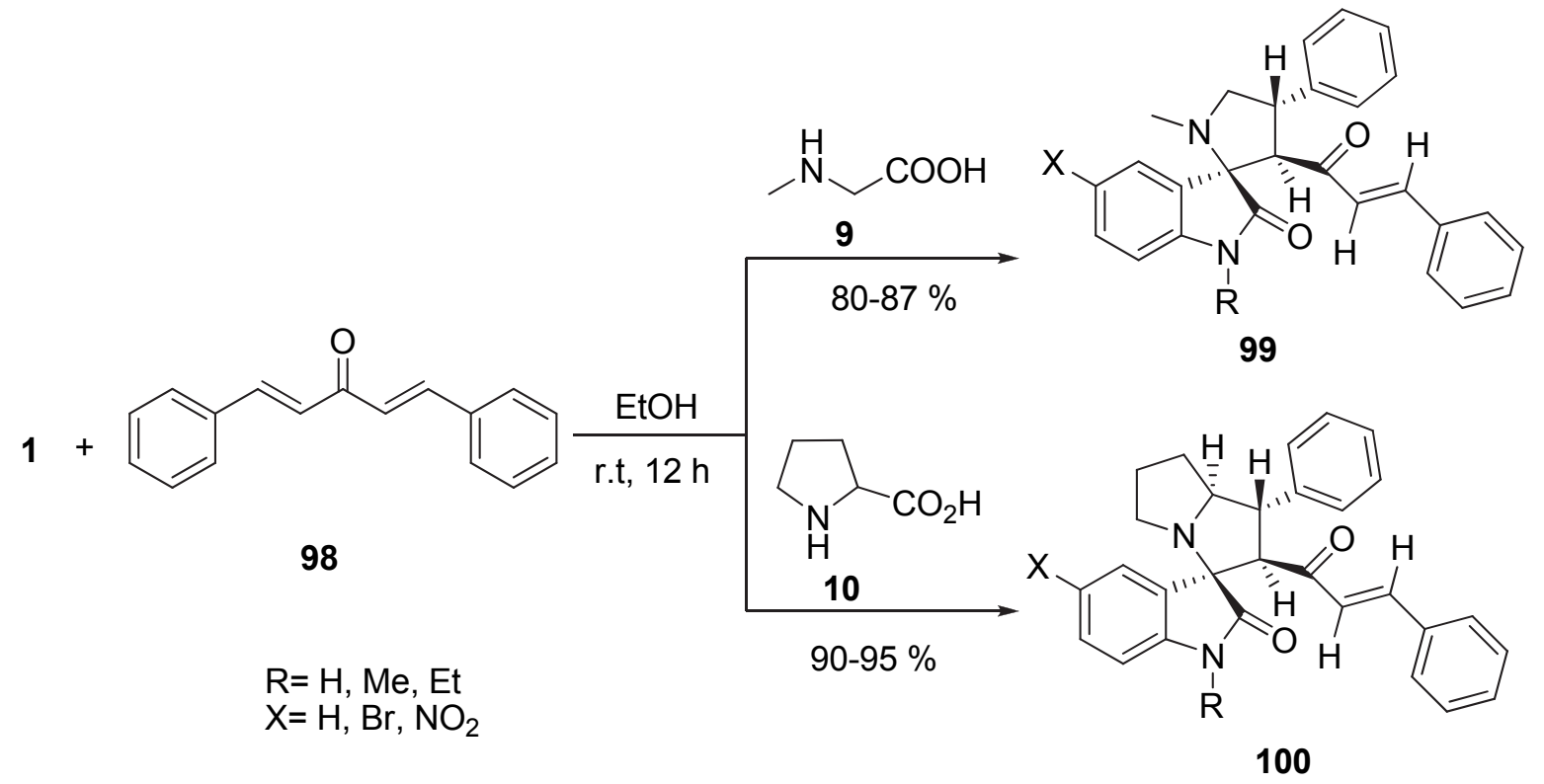

\section{Scheme 35}

The reactivity pattern of $E / Z$ isomerized alkyl 2-cyano-2-(2-oxoindolin-3-ylidene)acetate 101 was studied with azomethine ylide generated in situ from decarboxylative condensation of isatins $\mathbf{1}$ and sarcosine 9, yielding stereochemically different novel dispirobisoxindole derivatives through $[3+2]$ cycloaddition reaction. Investigating the reaction with azomethine ylide of sarcosine 9, $E$ isomer is taking part as a dipolarophile producing dispiropyrrolidinebisoxindoles 102 exclusively, while in case of azomethine ylide of proline $\mathbf{1 0}$, $Z$ isomer is participating to generate the dispiropyrrolizidine-bisoxindoles $\mathbf{1 0 3}$ as single product (Scheme 36). ${ }^{79}$

Synthesis of pyrrolidinyl-spirooxindoles fused to sugar lactone $\mathbf{1 0 5}$ has been achieved by 1,3-dipolar cycloaddition reaction. A unique dipolarophile ( $\alpha, \beta$-unsaturated lactone) derived from D-glucose/D-galactose 104, reacted with azomethine ylide generated in situ from isatin $\mathbf{1}$ and proline 10 to give the corresponding cycloadducts (Scheme 37 ). ${ }^{80}$ The cycloaddition was found to be highly regio- and diastereoselective. 


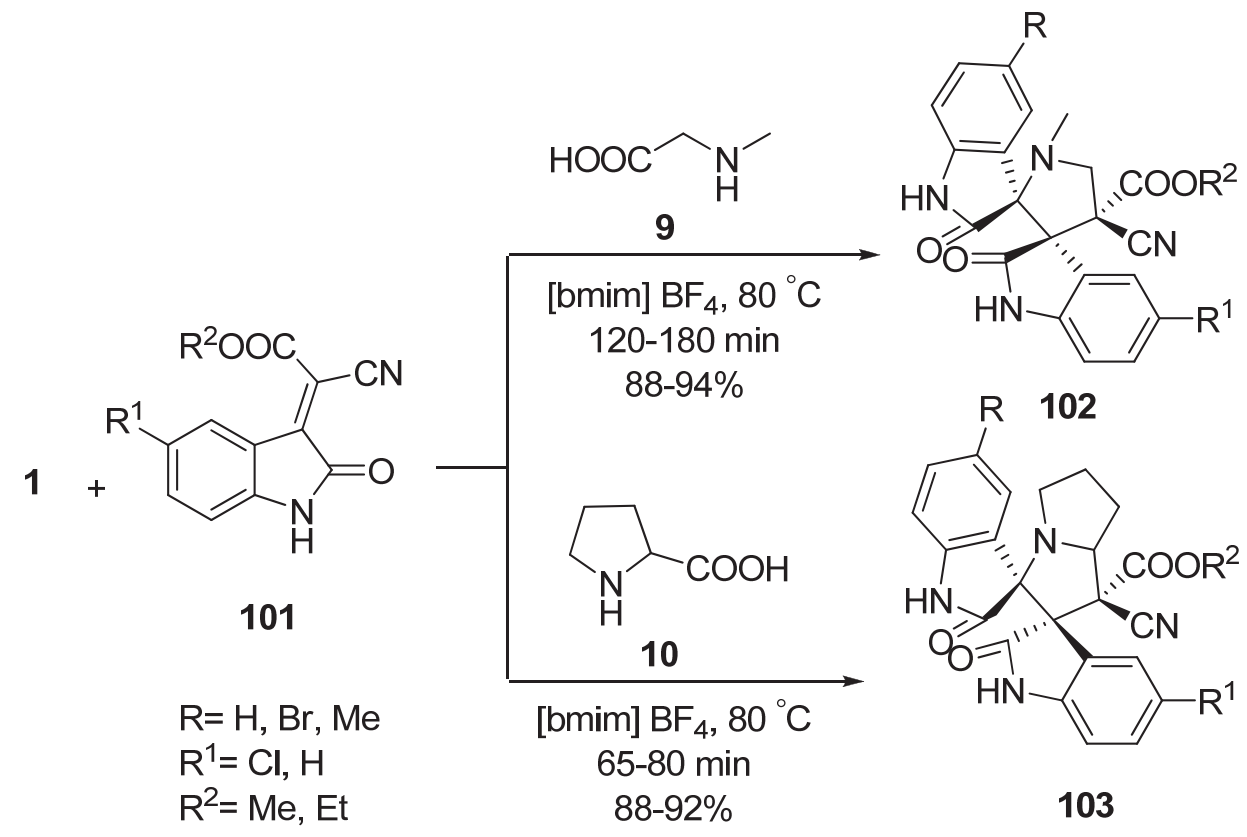

\section{Scheme 36}

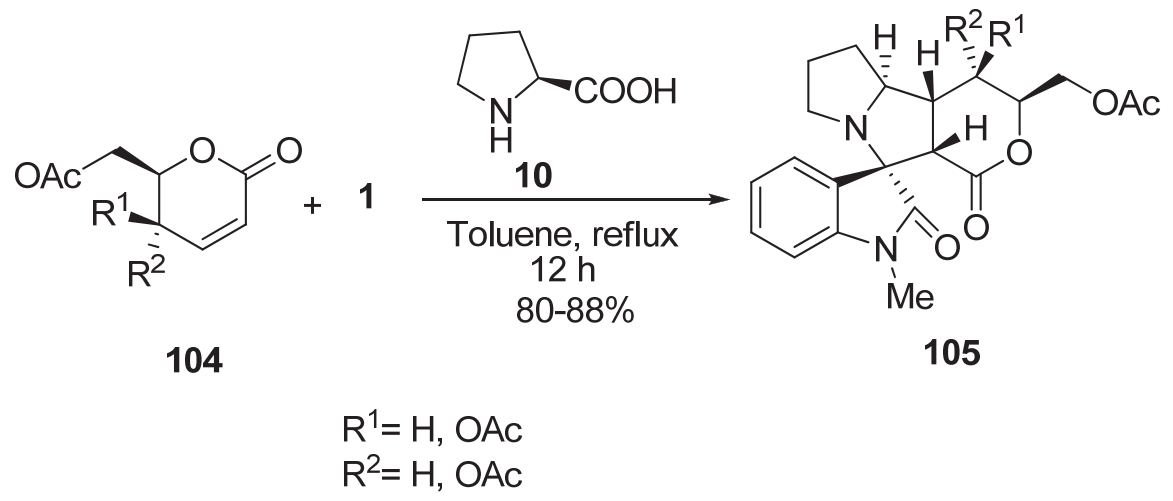

Scheme 37

Kumar and co-workers prepared diastereoselective spiropyrrolidine-oxindole derivatives 107 from isatins 1, 2-phenylthiazolidine-4-carboxylic acid 106 and chalcones 23 (Scheme 38). ${ }^{81}$ These derivatives exhibited promising anti-cancer activity against the human breast cancer cell lines. 


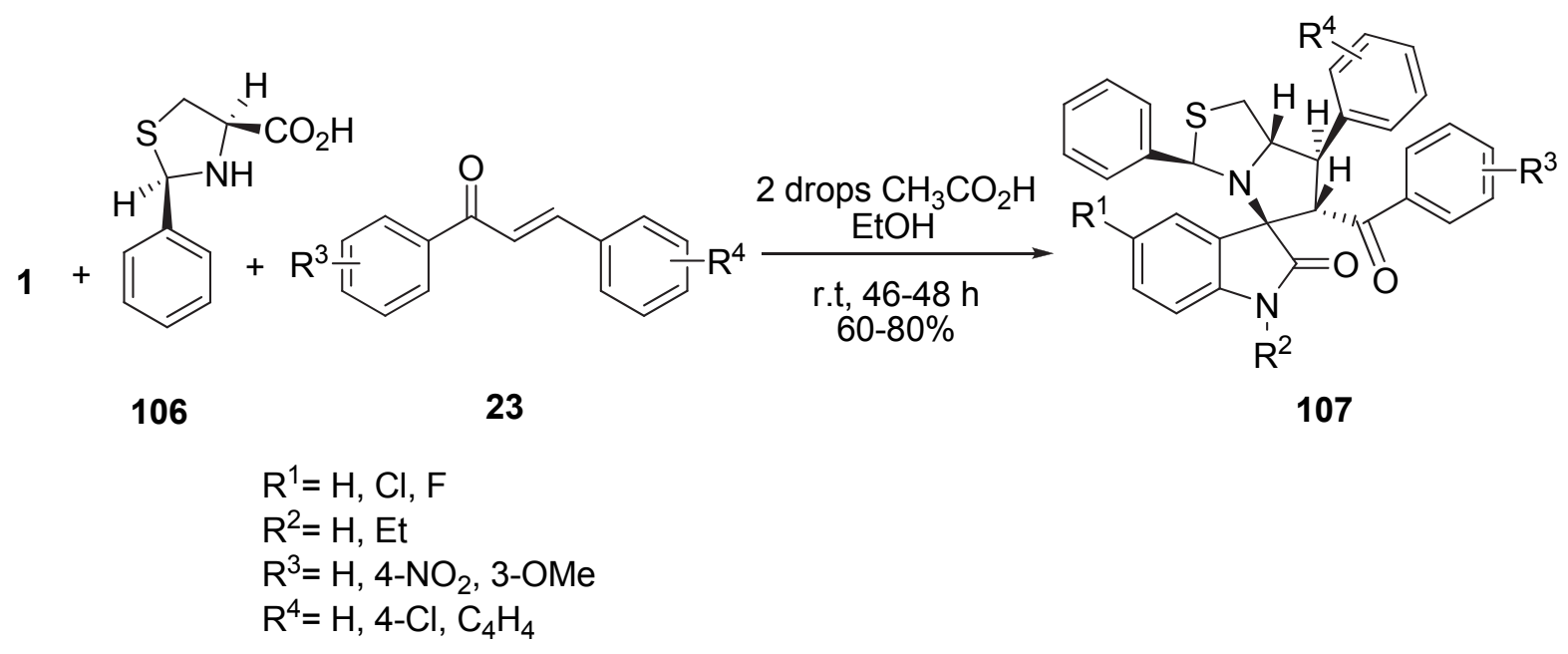

\section{Scheme 38}

Through the reaction of isatin $\mathbf{1}, \alpha$-amino acid 70, and phenothiazinyl chalcones $\mathbf{1 0 8}$, using the ZnS-nanoparticles, the spiro[pyrrolidine-2,3'-oxindole] derivatives 109 were synthesized (Scheme 39). ${ }^{82}$

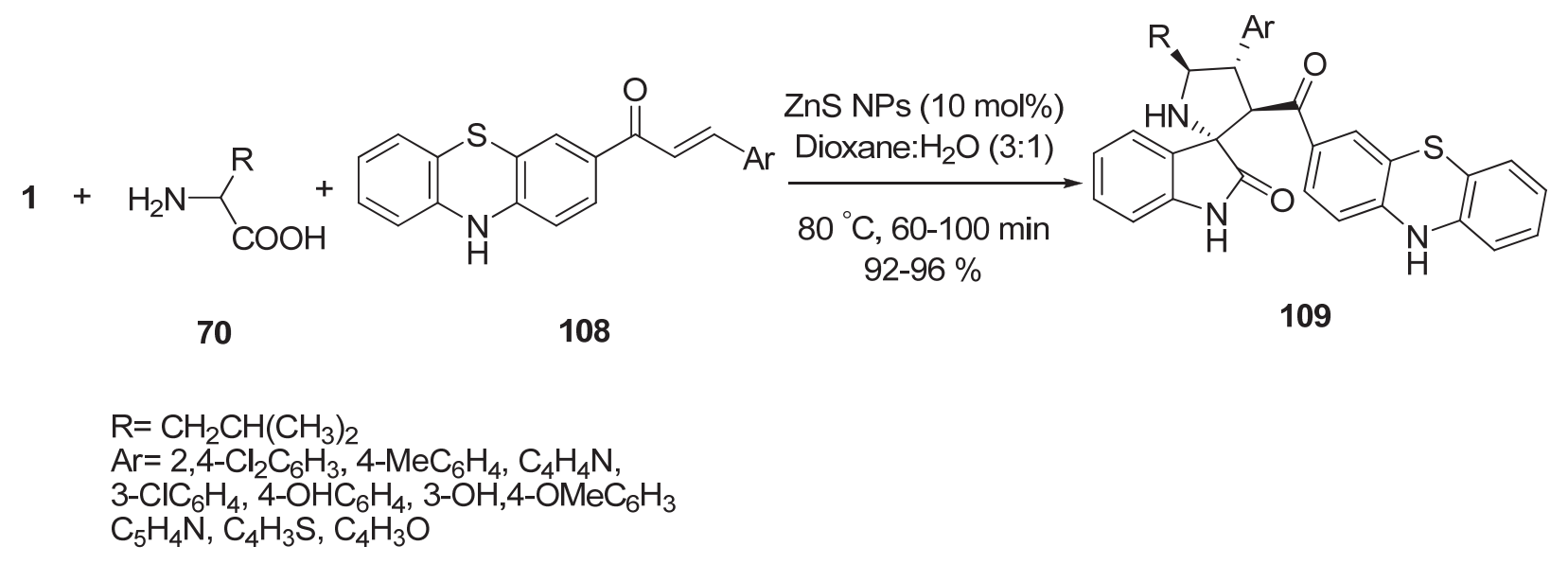

\section{Scheme 39}

The reactions of arylamines 110, acetylenedicarboxylates 32, and isatins $\mathbf{1}$ in the presence of $p$-toluenesulfonic acid as the catalyst, showed very interesting molecular diversity. When equal amount of arylamine was used, the three-component reaction resulted in high yields of functionalized $3^{\prime}$-hydroxyspiro[indoline-3,5'-pyrroline]-2,2'-dione derivatives 111 . On the other hand, the functionalized $3^{\prime}$ - $N$-arylaminospiro[indoline-3,5'-pyrroline]-2,2' ${ }^{\prime}$-diones 112 were successfully prepared in satisfactory yields by using $2 \mathrm{M}$ arylamine $\mathbf{1 1 0}$ in the reaction (Scheme 40). ${ }^{83} \mathrm{TiO}_{2}$-nanoparticles ${ }^{84}$ and $\mathrm{Et}_{3} \mathrm{~N}^{85}$ were also used as catalysts in this reaction. 


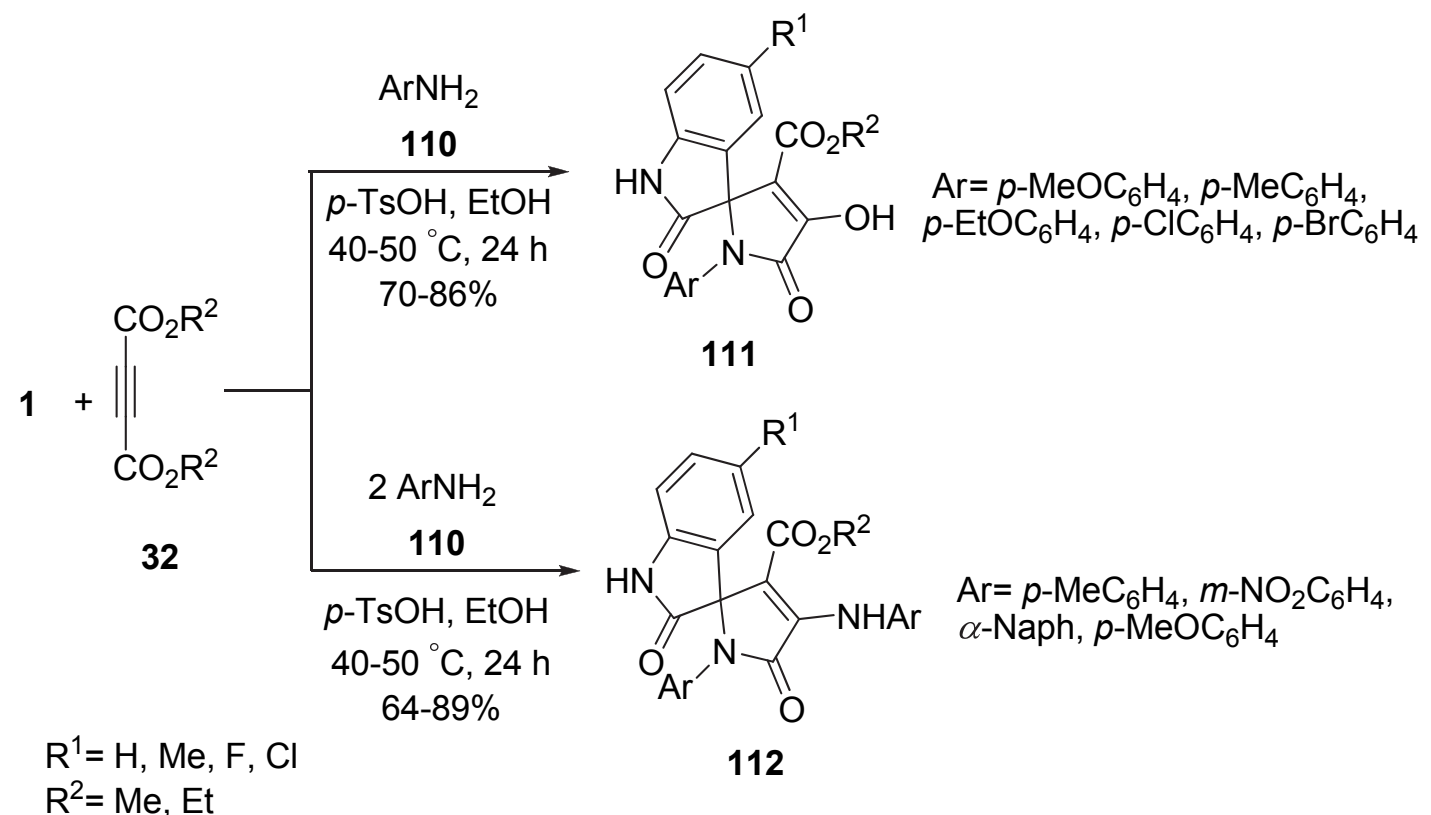

\section{Scheme 40}

Novel functionalized 1'-aryl-2' -(2-oxoindolin-3-yl)spiro[indoline-3,5' -pyrroline]-2,3' diones 114 were prepared in the reaction of arylamines 110, acetone 113, and isatins 1 (Scheme 41). ${ }^{86}$

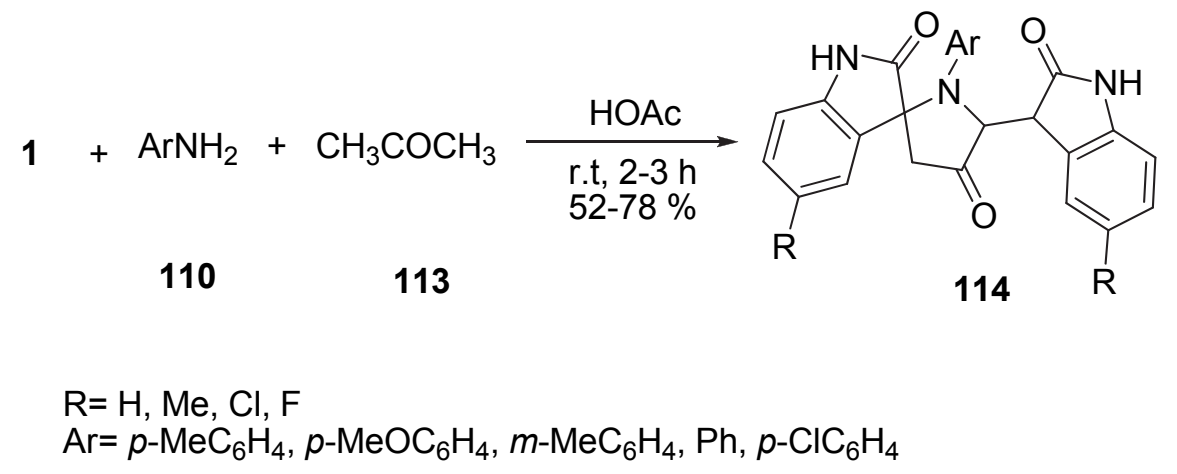

\section{Scheme 41}

Reaction of isatin 1, malononitrile 115, and hydantoin or thiohydantoin derivatives 116 using $\mathrm{Et}_{3} \mathrm{~N}$ as catalyst afforded spiro[indoline-3,7' -pyrrolo[1,2-c]imidazole]-6' ${ }^{\prime}$-carbonitrile derivatives 117 in good yields (Scheme 42). ${ }^{87}$ 


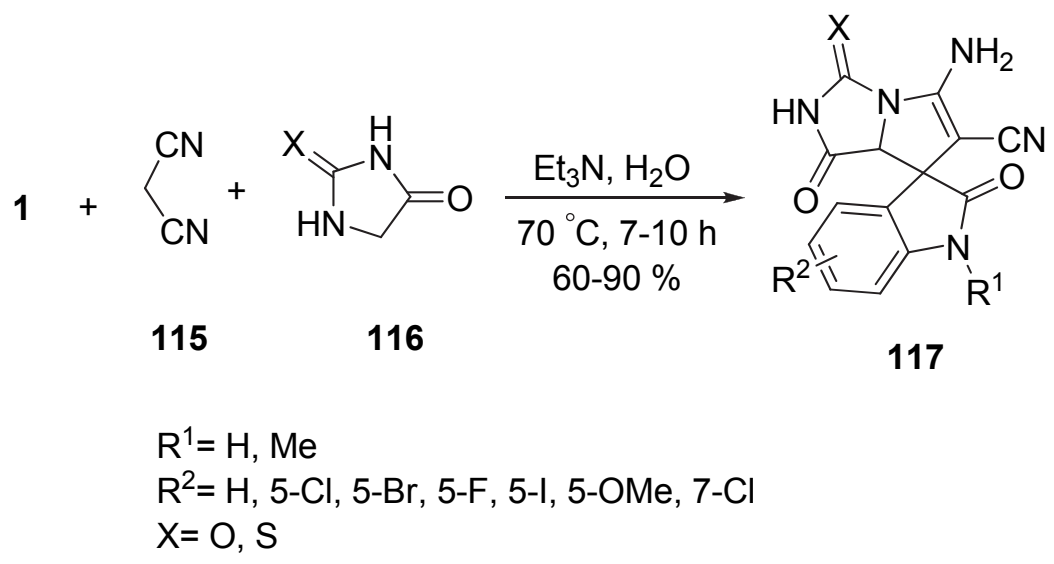

\section{Scheme 42}

Spiro[indoline-3,1'-pyrazolo[1,2-b]phthalazine] derivatives 119 were synthesized by the reaction of phthalhydrazide 118, isatins 1 , and malononitriles 115 using piperidine in $\mathrm{CH}_{3} \mathrm{CN}$ (Scheme 43). ${ }^{88}$ In another study, application of ultrasound in this reaction was investigated. ${ }^{89}$

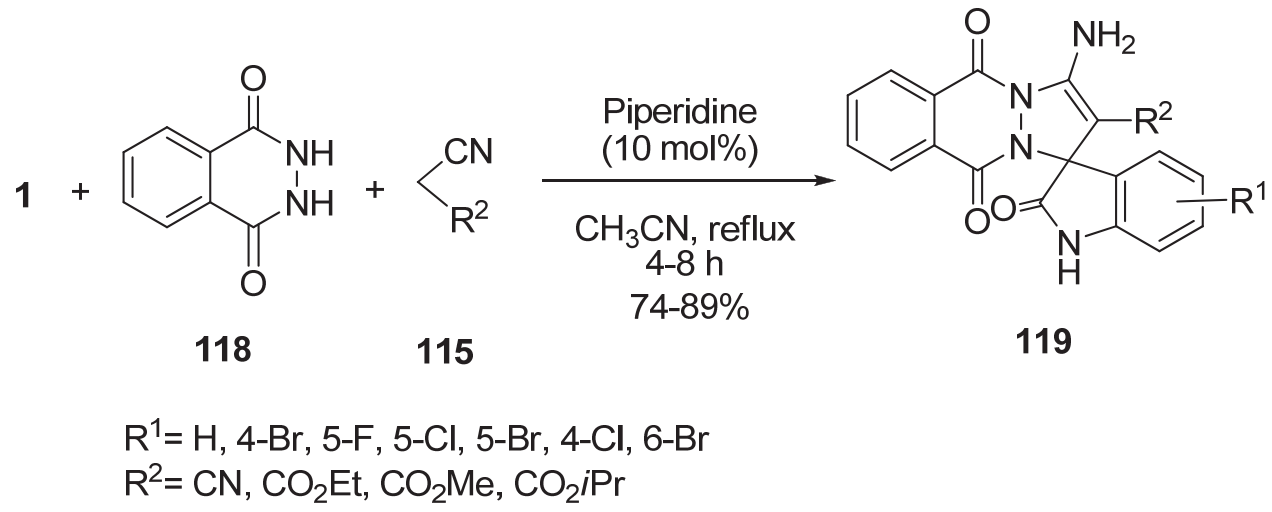

\section{Scheme 43}

A highly chemoselective method has been devised for the synthesis of a wide range of spirooxindolyl oxazolidines $\mathbf{1 2 3}$ via an intermolecular 1,3-dipolar cycloaddition of carbonyl ylides generated from dimethyl diazomalonate 121 and aromatic aldehydes 122, with cyclic ketimines 120 using $\mathrm{Rh}_{2}(\mathrm{OAc})_{4}$ under mild conditions (Scheme 44). ${ }^{90}$ Similarly, highly functionalized spirooxindolyl pyrrolines $\mathbf{1 2 4}$ have been prepared through 1,3-dipolar cycloaddition of azomethine ylides generated from dimethyl diazomalonate $\mathbf{1 2 1}$ and cyclic ketimines 120, with dimethyl acetylenedicarboxylate 32 (Scheme 44). ${ }^{90}$ 


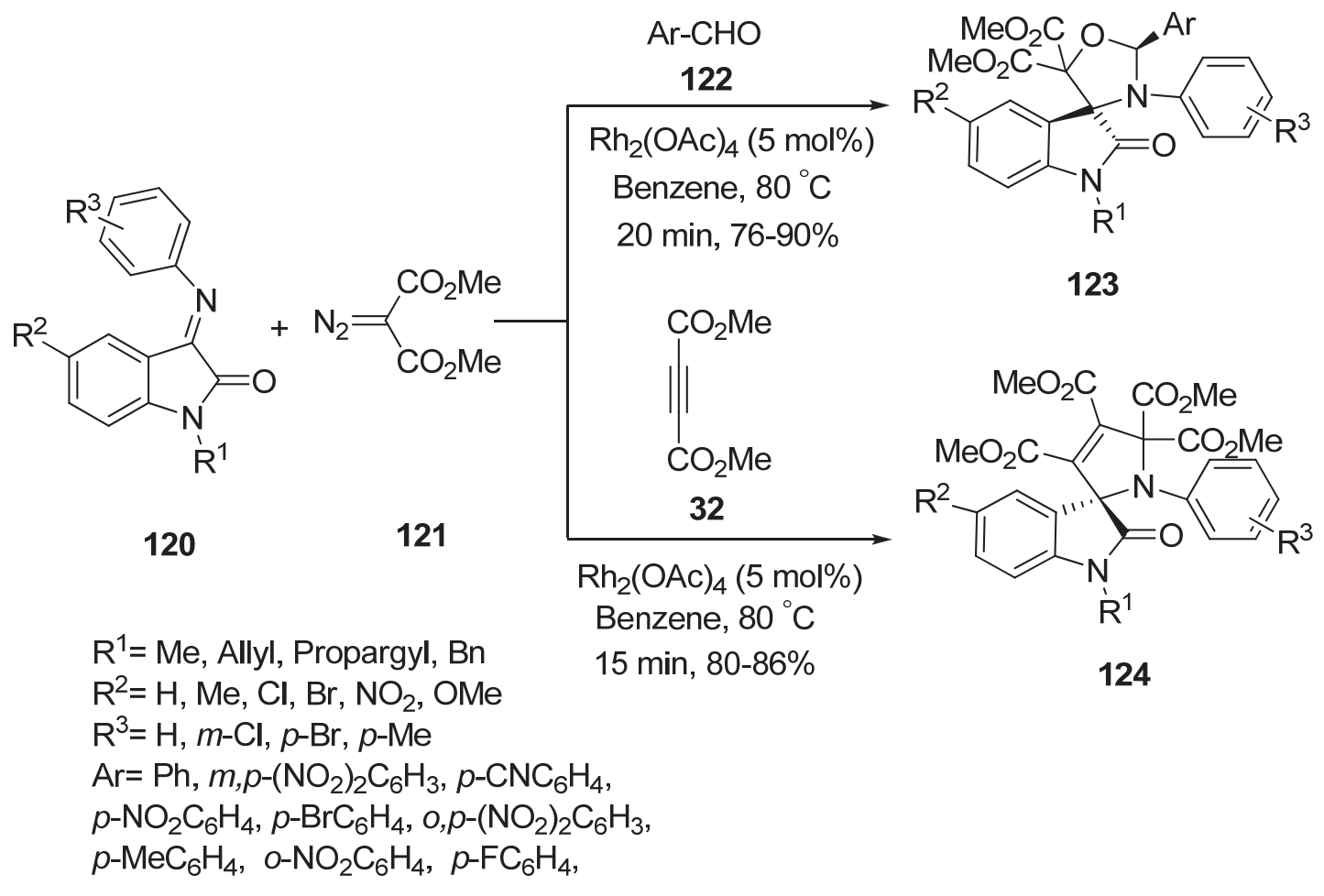

\section{Scheme 44}

An asymmetric 1,3-dipolar cycloaddition reaction of azomethine ylides with electrondeficient dipolarophiles, 3-(2-alkenoyl)-1,3-oxazolidin-2-ones 125, to give optically active spiropyrrolizidineoxindoles $\mathbf{1 2 6}$ in good yields with high regio-, diastereo-, and enantioselectivities (up to $93 \%$ ee) was described by Salahi et al. (Scheme 45). ${ }^{91}$

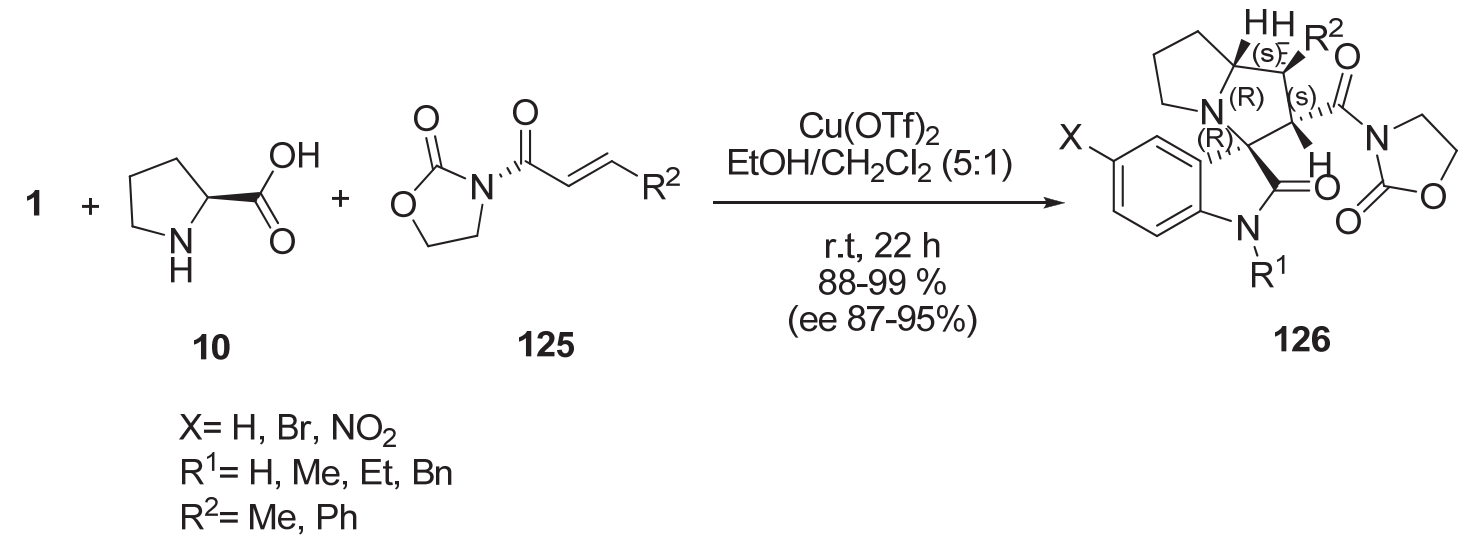

\section{Scheme 45}

Chandam et al. reported the synthesis of spiro triazolo[1,2-a]indazole-tetraones 129 by condensation reaction of dimedone 127 urazole 128 and isatins 1 in the presence of $( \pm)$-camphor- 
10-sulfonic acid (CSA) as a Bronsted acid catalyst (Scheme 46). ${ }^{92}$

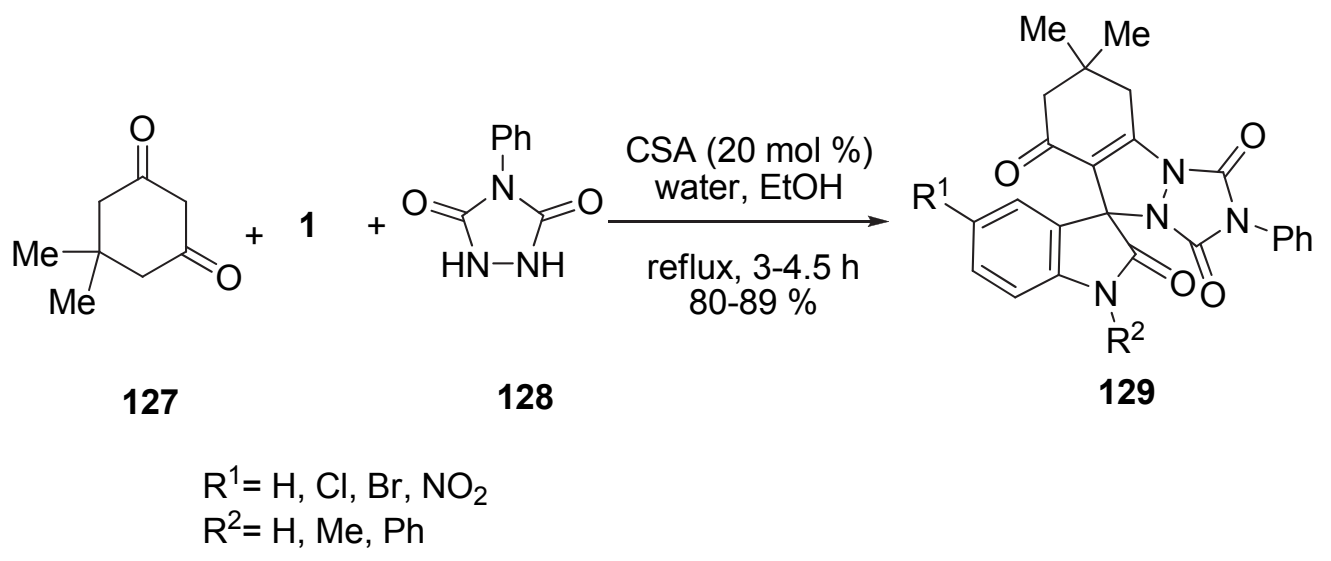

\section{Scheme 46}

Singh and co-workers have developed a versatile one pot catalyst-free multicomponenttandem strategy for assembly of spirooxindole-indazolones $\mathbf{1 3 1}$ via the reaction of isatins $\mathbf{1}$, hydrazines 130, and dimedones 127 in glycerol-water solvent system (Scheme 47). ${ }^{93}$ In all the cases the desired products were obtained in high yields and short reaction times.

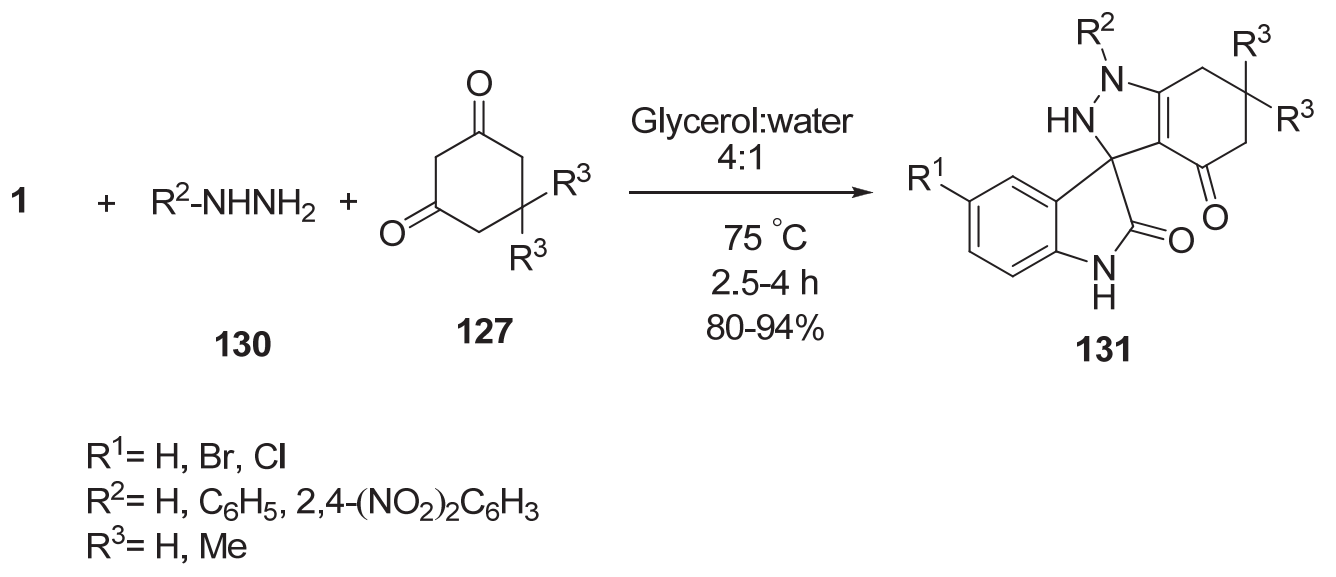

\section{Scheme 47}

Hamama's group reported the synthesis of spirotriazoles $\mathbf{1 3 4}$ by the reaction of isatin $\mathbf{1}$, thiosemicarbazide 132 and 2-amino-1,3,4-thiadiazole 133 in acetic acid (Scheme 48). ${ }^{94}$ These compounds were evaluated as antitumor agents. 
<smiles></smiles>

\section{Scheme 48}

Spiro[3H-indole-3,2'-thiazolidine]-2,4'(1H)-diones 137 were synthesized by a facile onepot, three-component protocol using isatins 1, $4 H-1,2,4$-triazol-4-amine 135, and 2sulfanylpropanoic acid $\mathbf{1 3 6}$ in $\left[\mathrm{bmim}_{\mathrm{PF}}\right.$ (1-butyl-3-methyl-1H-imidazolium hexafluorophosphate) as a recyclable ionic-liquid (Scheme 49). ${ }^{95}$

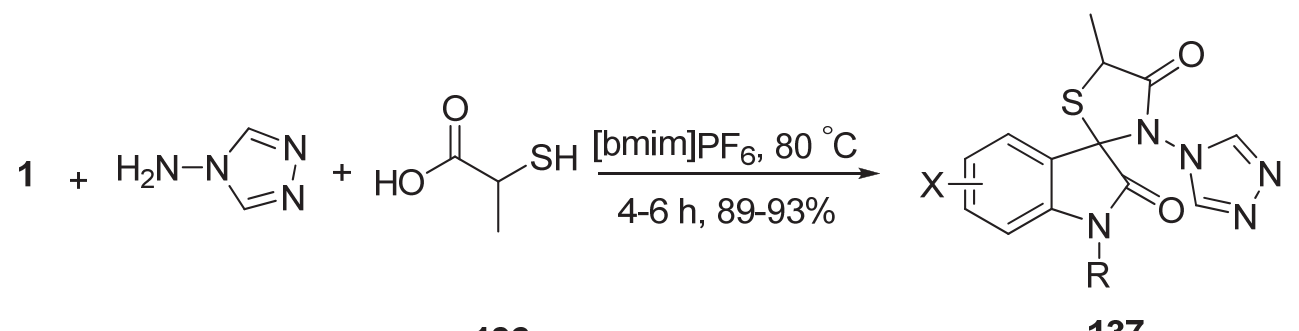

135 136

137

$$
\begin{aligned}
& \mathrm{R}=\mathrm{H}, \mathrm{Ac}, \mathrm{Me}, \mathrm{Et}_{2} \mathrm{NCH}_{2}, \mathrm{Me}_{2} \mathrm{NCH}_{2}, \\
& \mathrm{Bn}, \mathrm{Me} \text {, piperidin-1ylmethyl } \\
& \mathrm{X}=\mathrm{H}, 5-\mathrm{Cl}, 5-\mathrm{F}
\end{aligned}
$$

\section{Scheme 49}

The synthesis of new dispiropyrrolidines containing a thiophenone ring $\mathbf{1 3 9}$ has been achieved by Moghaddam and co-workers. Unsaturated thiophenone dipolarophiles 138 were reacted with azomethine ylides, generated in situ from sarcosine $\mathbf{9}$ and isatins $\mathbf{1}$, to produce the corresponding cycloadducts (Scheme 50). ${ }^{96}$ The cycloaddition reaction was found to be highly regio- and diastereoselective. 


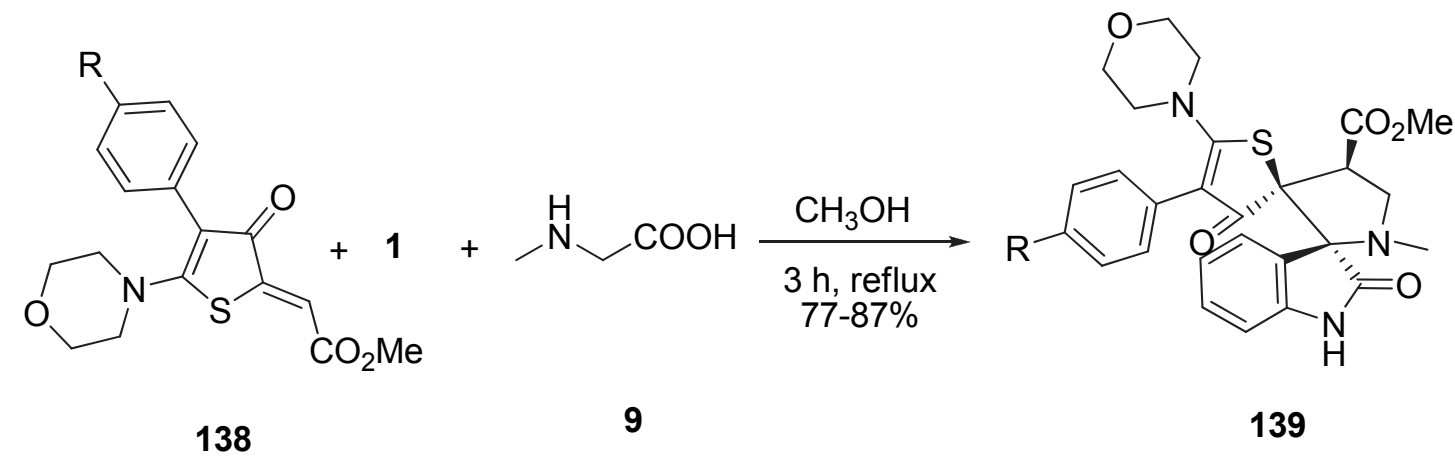

$\mathrm{R}=\mathrm{H}, \mathrm{Br}, \mathrm{Me}, \mathrm{Ph}$

\section{Scheme 50}

2.1.2. Six-membered spiro-fused compounds. Enantioselective isatin-involved Povarov reaction, which is applicable to a variety of reaction components, was used for the synthesis of new spiro-[indolin-3,2'-quinolines] 141 with concomitant creation of two quaternary stereogenic centers in high yields and excellent stereoselectivities. This transformation was created by isatins 1, anilines 110, and $\alpha$-alkyl $o$-hydroxystyrenes 140 in the presence of the chiral catalyst (binaphthol derived phosphoric acid) (Scheme 51). ${ }^{97}$

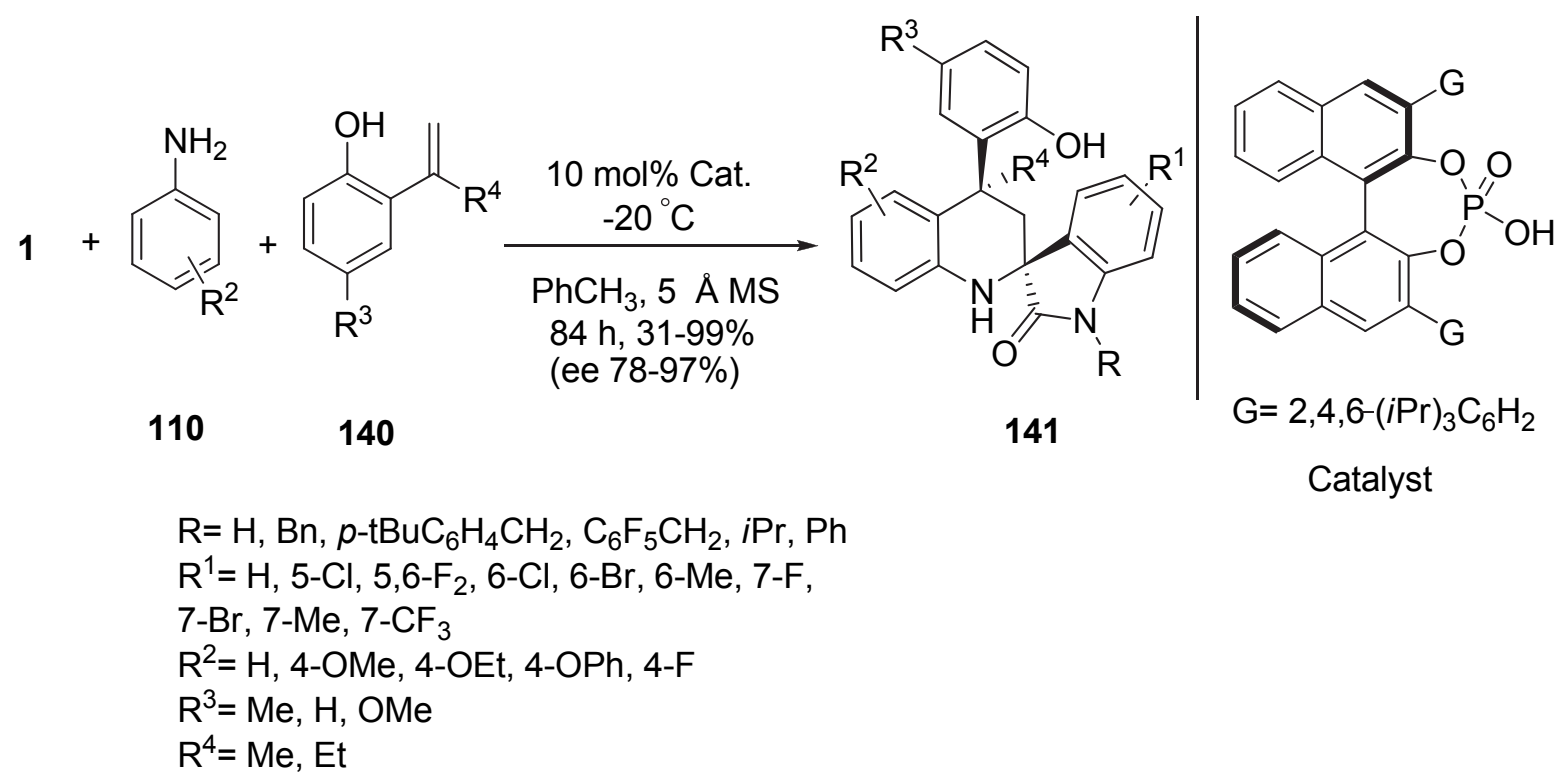

\section{Scheme 51}

The same group employed isatin-derived 3-indolylmethanols 142 as dipolarophiles to undergo catalytic asymmetric formal [3+3] cycloadditions with 4-nitrobenzaldehyde 122, and diethyl 2-amino-malonate 35 in the presence of a chiral catalyst, affording stereoselective 
spiro[indoline-3,4'-pyridoindoles] 143 , in which a six-membered piperidine framework would be constructed (Scheme 52) ${ }^{98}$ Replacement of 4-nitrobenzaldehyde 122 with isatins in this reaction leads to the synthesis of a new class of bispirooxindole scaffold-containing tetrahydro- $\beta$ carboline moiety in excellent stereoselectivities (all $>95: 5$ diastereomeric ratio (d.r.), up to 98:2 enantiomeric ratio (e.r.)). ${ }^{99}$

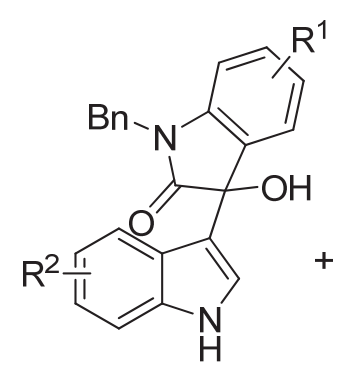

142<smiles>CCOC(=O)C(N)C(=O)OCC</smiles>

cat. $10 \mathrm{~mol} \%$

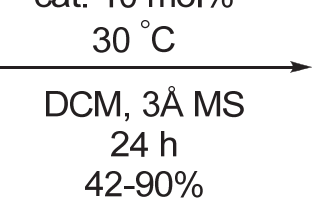

(ee 79 - >99\%)

35

$\mathrm{R}^{1}=7-\mathrm{F}, 7-\mathrm{Br}, 7-\mathrm{Me}, 6-\mathrm{Cl}, 6-\mathrm{Br}, 5-\mathrm{Cl}, 5-\mathrm{Me}$ $\mathrm{R}^{2}=\mathrm{H}, 7^{\prime}-\mathrm{Me}, 6^{\prime}-\mathrm{Me}, 5^{\prime}-\mathrm{Me}, 5^{\prime}-\mathrm{F}$

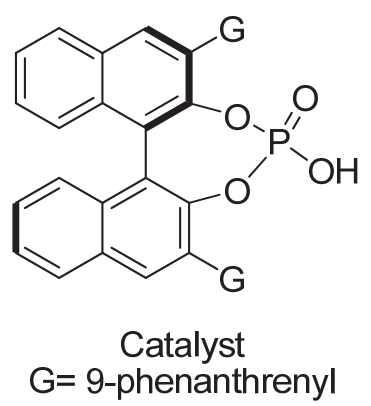<smiles></smiles>

143

\section{Scheme 52}<smiles>[R]N1C(=O)CC(=O)N([R])C1=[V]</smiles>

144<smiles>[Z]c1ccc(-n2nc(-c3ccccc3)cc2N)cc1</smiles>

145<smiles></smiles>

146

$\mathrm{R}^{1}=\mathrm{H}, \mathrm{Et}, \mathrm{Me}$

$\mathrm{R}^{2}=\mathrm{H}, \mathrm{Me}$

$\mathrm{X}=\mathrm{H}, \mathrm{Me}, \mathrm{Br}, \mathrm{NO}_{2}$

$Y=O, S$

$\mathrm{Z}=\mathrm{H}, \mathrm{NO}_{2}$

\section{Scheme 53}


Synthesise of spiro[indoline-pyrazolo[ $\left[4^{\prime}, 3^{\prime}: 5,6\right]$ pyrido[2,3-d]pyrimidine]trione derivatives 146 by a cyclocondensation reaction of isatins 1 , barbituric acids 144, and 1,3-diphenyl- $1 H$ pyrazol-5-amines 145 in [Bmim] $\mathrm{PF}_{6}$ medium and in the presence of alum as a reusable catalyst was reported by Shirvan et al. (Scheme 53). ${ }^{100}$ A simple and efficient method for the synthesis of pyrazolopyridine based spirooxindoles was also reported by Kamal and co-workers where isatins, 5-phenyl-1H-pyrazol-3-amine and 1,3-dicarbonyl compounds react in the presence of sulfamic acid $\left(\mathrm{H}_{2} \mathrm{NSO}_{3} \mathrm{H}\right)$ as a green catalyst. ${ }^{101}$

The three-component reactions of isatins 1, cyclic-1,3-diones 127, and pyrazol-5-amine 147 were successfully established and led to the formation of pyrazole-fused 1,4-dihydropyridine skeletons 148 using the heterogeneous aluminosilicate nanoparticle catalyst under eco-friendly conditions (Scheme 54). ${ }^{102}$<smiles>[R]C1([R])CC(=O)CC(=O)C1</smiles>

127

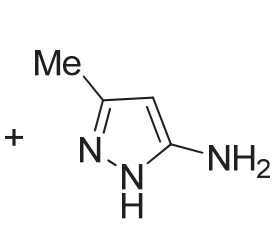

147
$\mathrm{H}_{2} \mathrm{O} / \mathrm{EtOH}$ (5:1) Alumino silicate NP (10 mg)

Reflux $\left(70-80{ }^{\circ} \mathrm{C}\right)$ $4 \mathrm{~h}$ $76-89 \%$<smiles>[R]c1ccc2c(c1)C1(C(=O)N2[R14])C2=C(CC([R])([R])CC2=O)Nc2[nH]nc(C)c21</smiles>

148

$$
\begin{aligned}
& \mathrm{R}^{1}=\mathrm{H}, \text { Allyl, benzyl } \\
& \mathrm{R}^{2}=\mathrm{H}, \mathrm{Br}, \mathrm{Cl}, \mathrm{Me}, \mathrm{NO}_{2} \\
& \mathrm{R}^{3}=\mathrm{H}, \mathrm{Me}, \mathrm{Ph}
\end{aligned}
$$

\section{Scheme 54}

Rahmati and Khalesi described the condensation reaction of isatins 1, isoxazole 149, and barbituric acids 144 in water to give spirooxindoles 150, using a catalytic amount of $p$-toluene sulfonic acid (Scheme 55). ${ }^{103}$ Reddy's group used dimedone instead of barbituric acid in an alternative strategy to obtain oxazolo[5,4-b]quinoline-fused spirooxindoles in the presence of microwave irradiation under solvent-free condition. ${ }^{104}$

Sulfonic acid functionalized SBA-15 ( $\left.\mathrm{SBA}-\mathrm{Pr}-\mathrm{SO}_{3} \mathrm{H}\right)$ as a new nanoporous solid acid catalyst was applied in the green one-pot synthesis of spiro[indole-tetrahydro-pyrano(2,3d)pyrimidine] derivatives $\mathbf{1 5 1}$ via three-component reaction of isatins $\mathbf{1}$, malononitrile or cyanoacetic esters 115 and barbituric acids 144 under solvent-free conditions (Scheme 56). ${ }^{105}$ 


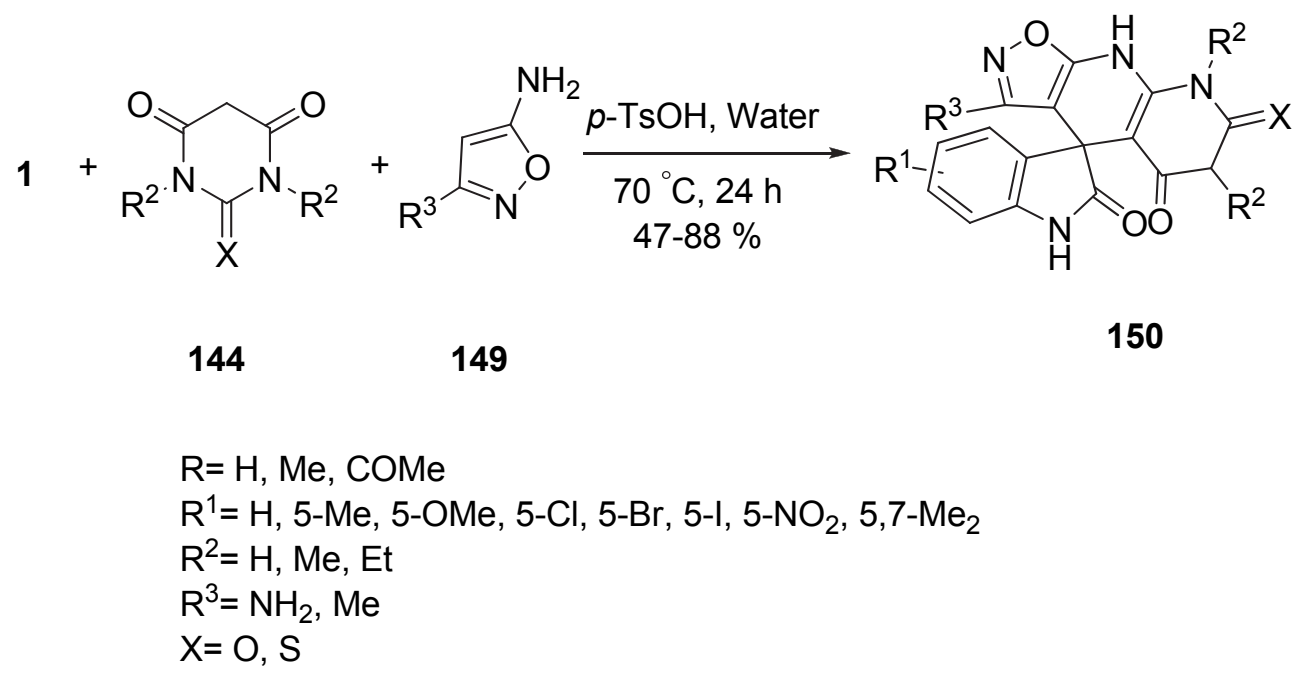

\section{Scheme 55}

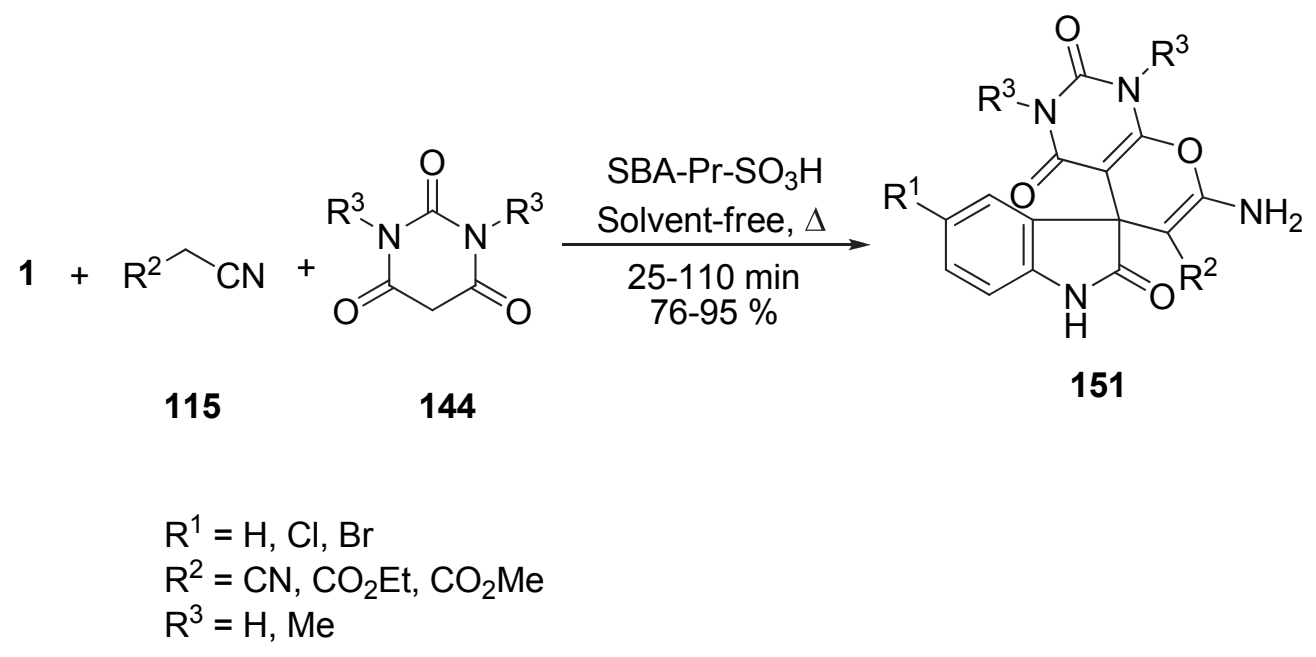

\section{Scheme 56}

Synthesis of pyrazolopyridinyl spirooxindoles 153-154 has been developed through a reaction of isatins 1 , malononitrile/ethyl cyanoacetate 115, and 5-amino-3-methylpyrazole 152 catalyzed by sodium chloride in water (Scheme 57). ${ }^{106}$ The product showed high diastereoselectivity in which the stereochemistry of major diastereomer was confirmed by X-ray diffraction analysis. In another study, $\mathrm{Et}_{3} \mathrm{~N}$ was used as the catalyst of this reaction. ${ }^{107}$

Isatin 1, malononitrile 115, and 2,3-dihydro-5H-[1,3]thiazolo[3,2-a]pyrimidine-5,7(6H)dione 155 in the presence of diisopropylethylamine (DIEA) yielded novel spirooxindole derivatives 156 in excellent yields (Scheme 58). ${ }^{108}$ 


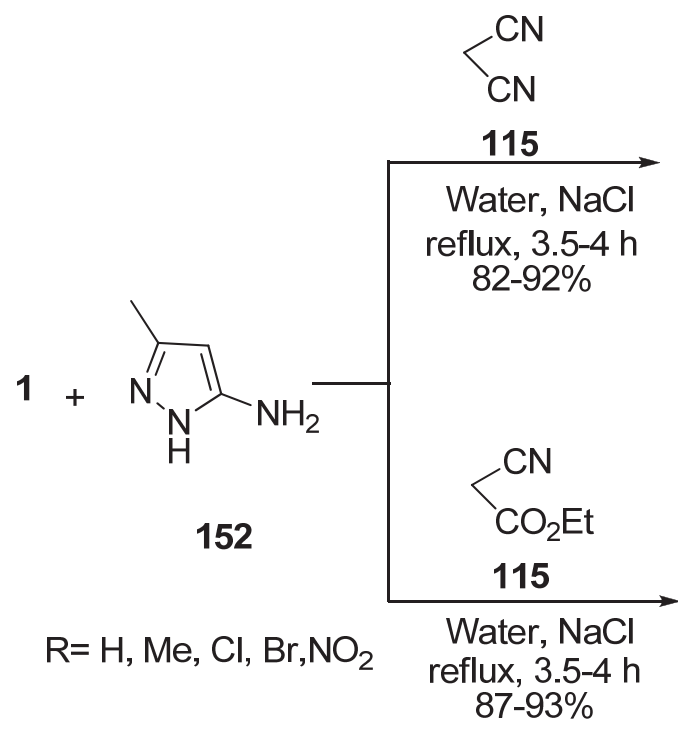

$87-93 \%$<smiles>[R]c1ccc2c(c1)C1(C(=O)N2)C(C#N)=C(N)Nc2n[nH]cc21</smiles>

153<smiles>[R]c1ccc2c(c1)C1(C(=O)N2)c2c[nH]nc2NC(=O)C1C#N</smiles>

154

\section{Scheme 57}

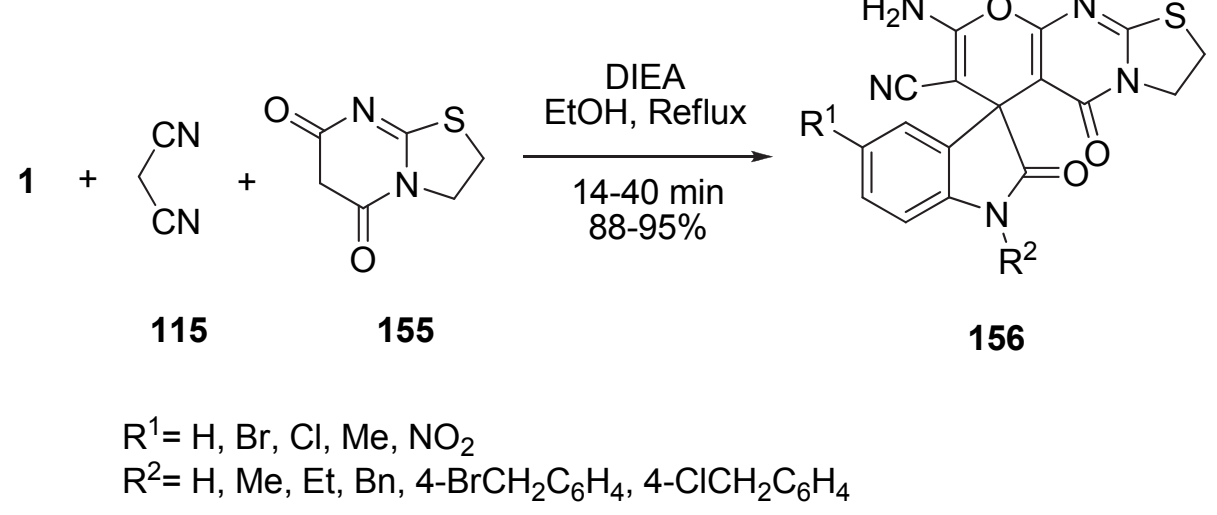

\section{Scheme 58}

Treatment of pyridine $\mathbf{1 5 8}$ and acetylenedicarboxylate esters $\mathbf{3 2}$ with $N$-substituted isatylidene derivatives 157 resulted in three-component condensations, affording spiro[indoline3,3'-piperidin]-2-one derivatives 159 in high yields and with good diastereoselectivities through 1,4-dipolar cycloadditions (Scheme 59). ${ }^{109}$ Based on a plausible mechanism, pyridine 158 could first attack activated alkyne 32 to afford inter mediates $\mathbf{a}$ or $\mathbf{b}$. Intermediates $\mathbf{a}$ or $\mathbf{b}$, acting as 1,3dipole or 1,4-dipole, could then react with isatylidene $\mathbf{1 5 7}$ to give the product $\mathbf{1 5 9}$ in a concerted manner. Alternatively, 1,3-dipole a or 1,4-dipole b could attack the activated isatylidene $\mathrm{C}=\mathrm{C}$ bond to give intermediate $\mathbf{c}$, which could undergo cyclization to give the product $\mathbf{1 5 9}$ (stepwise pathway). 


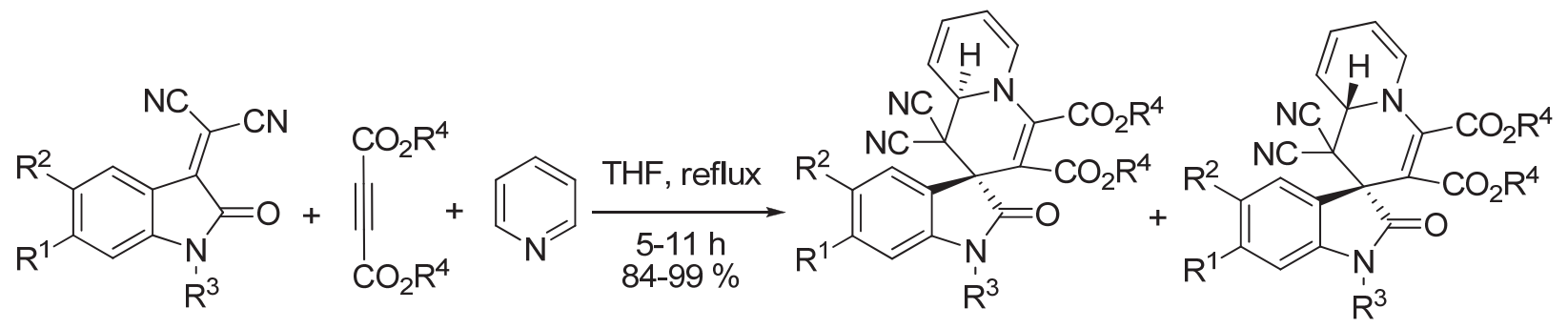
157 32

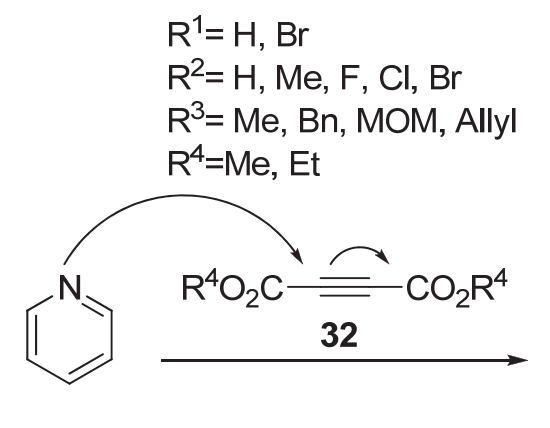<smiles>[R]OC(=O)C=C(C(=O)O[R2])N1[CH]C=CC=C1</smiles>

158

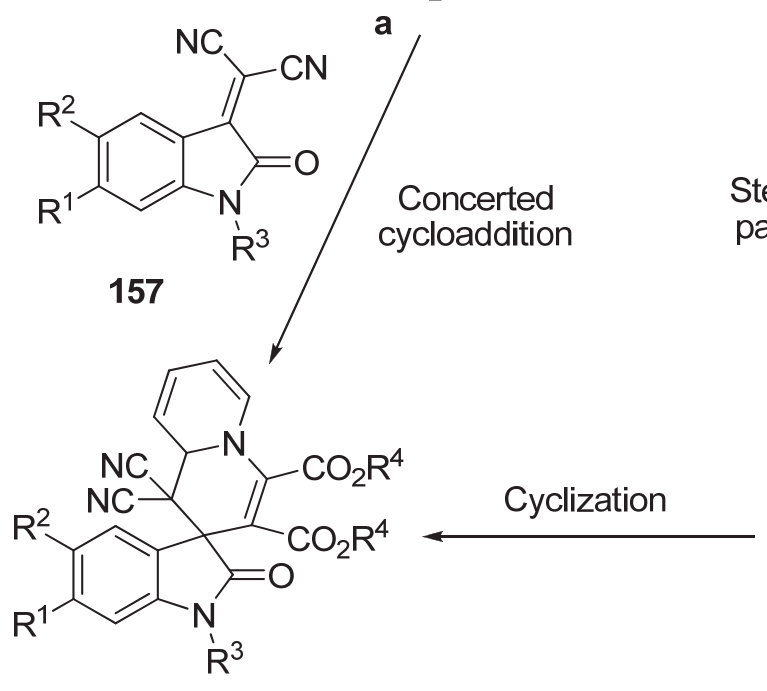

159

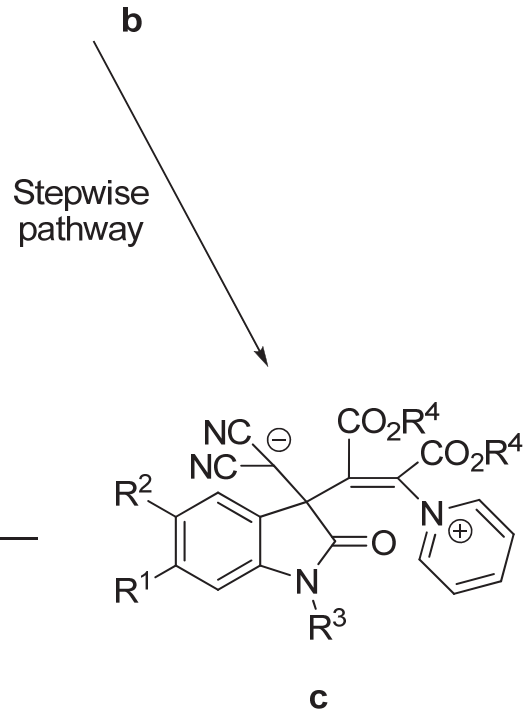

\section{Scheme 59}

A series of spirooxindole derivatives $\mathbf{1 6 3}$ were synthesized using isatin derivatives $\mathbf{1}$, cyanoacetamide 160, and 1,3-dicarbonyl compounds 162 as starting materials via one-pot threecomponent enzymatic or two-step chemo-enzymatic domino reactions, respectively (Scheme 60). ${ }^{110}$ In the single Acylase 'Amano'-catalyzed one-pot reaction, moderate yields of the products were obtained while the developed chemo-enzymatic route in two steps was able to prepare the final products in nearly quantitative yields. 


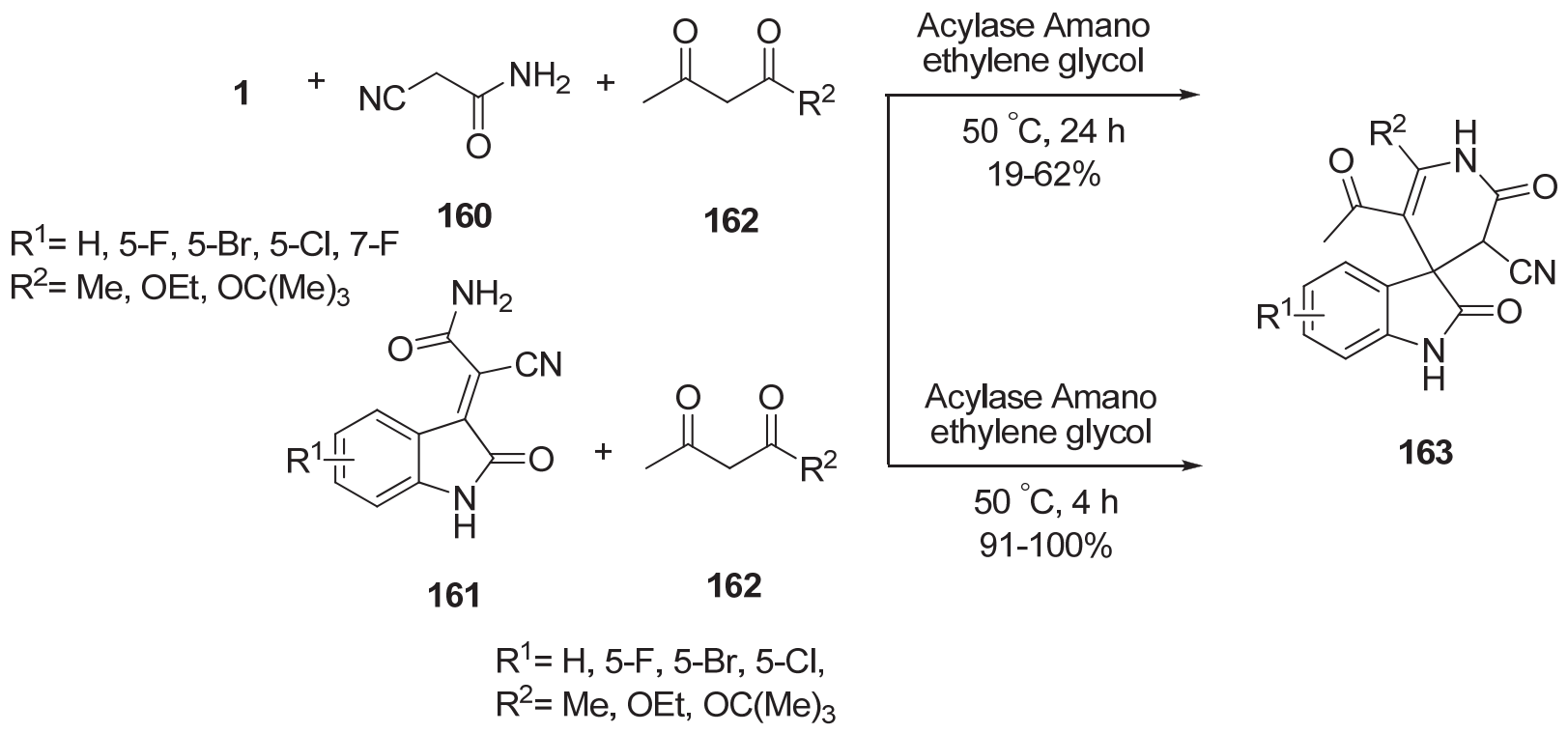

\section{Scheme 60}

$\mathrm{Yu}$ et al. synthesized spirooxindoles $\mathbf{1 6 6}$ by refluxing a mixture of ketene aminals 164, isatins 1 and ethyl trifluoroacetate 165 in the presence of piperidine (Scheme 61). ${ }^{111}$ The resulting compounds were generated with excellent regio- and diastereo-selectivity.

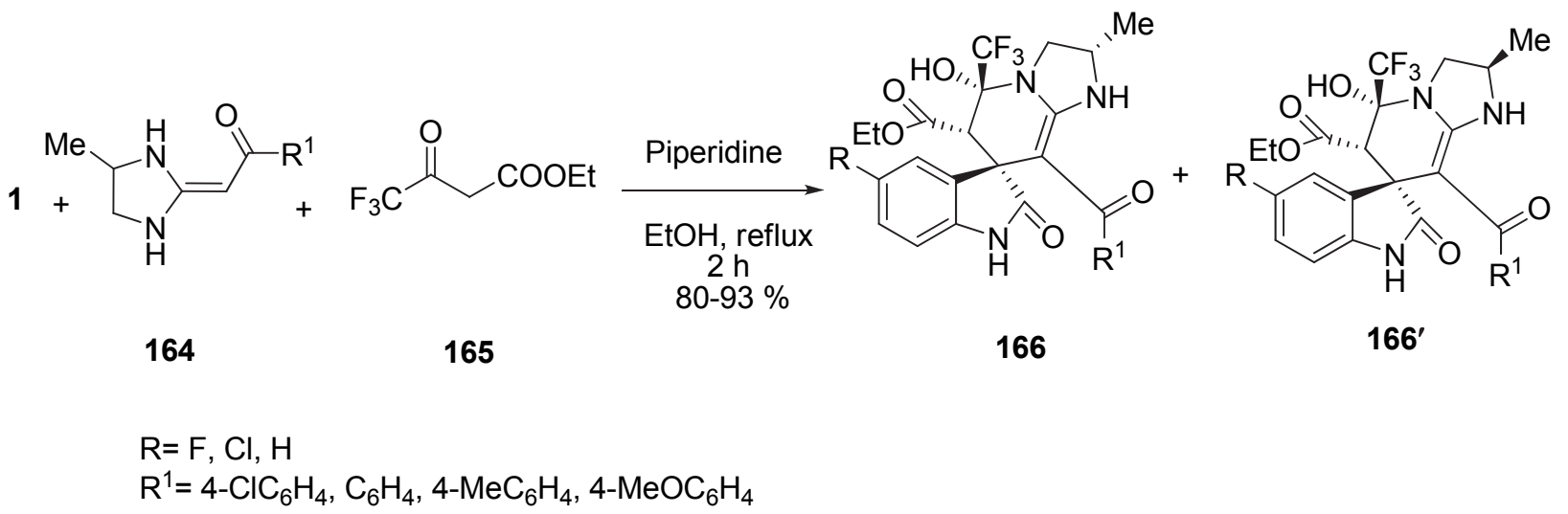

\section{Scheme 61}

Reaction of isatin 1 with ethyl cyanoacetate $\mathbf{1 1 5}$ and hexahydro-2(nitromethylidene)pyrimidine $\mathbf{1 6 7}$ in the presence of a catalytic amount of $\mathrm{NaCl}$ in $\mathrm{H}_{2} \mathrm{O}$ resulted in the synthesis of spirooxindoles of type 168 (Scheme 62). ${ }^{112}$ Utilizing $\mathrm{NaCl}$ as catalyst caused the ester group taking part in the cyclization, and, therefore, the yield of new spirooxindole 168 increased. It is conceivable that, initially, intermediate $\mathbf{A}$ is formed via the Knoevenagel condensation of isatin $\mathbf{1}$ and ethyl cyanoacetate 111, followed by Michael addition of ketene aminal 163 to afford intermediate B. Intramolecular cyclization of B may proceed in two path 
ways. Attack of the $\mathrm{NH}$ group to the ester or $\mathrm{CN}$ group generate spirooxindole 164 or $\mathbf{1 6 5}$, respectively.

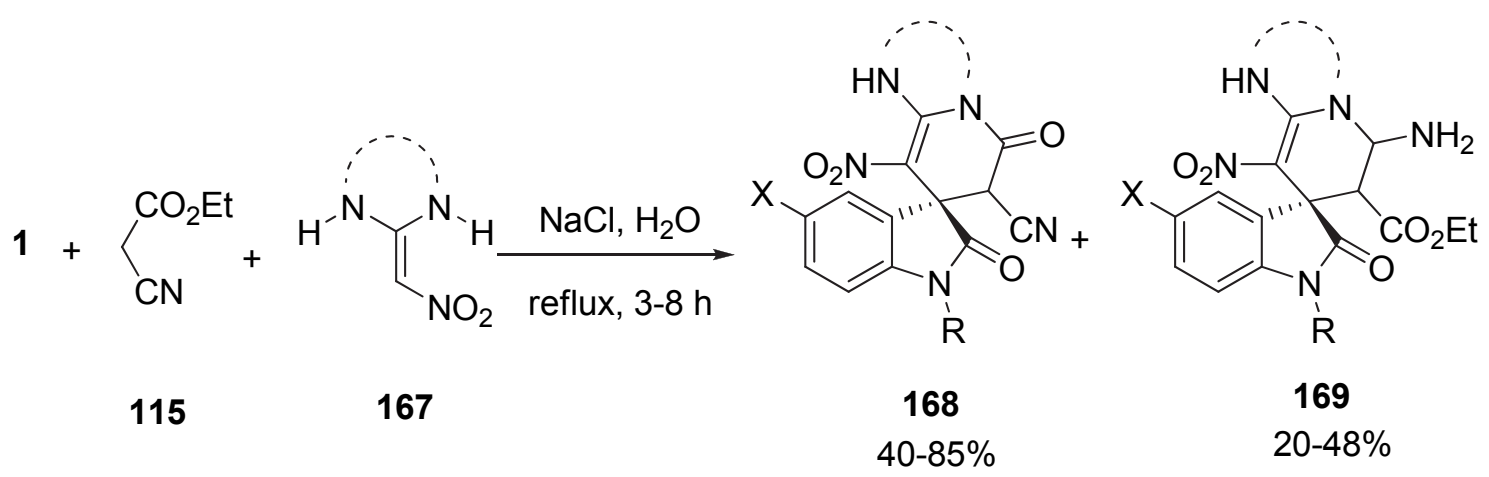

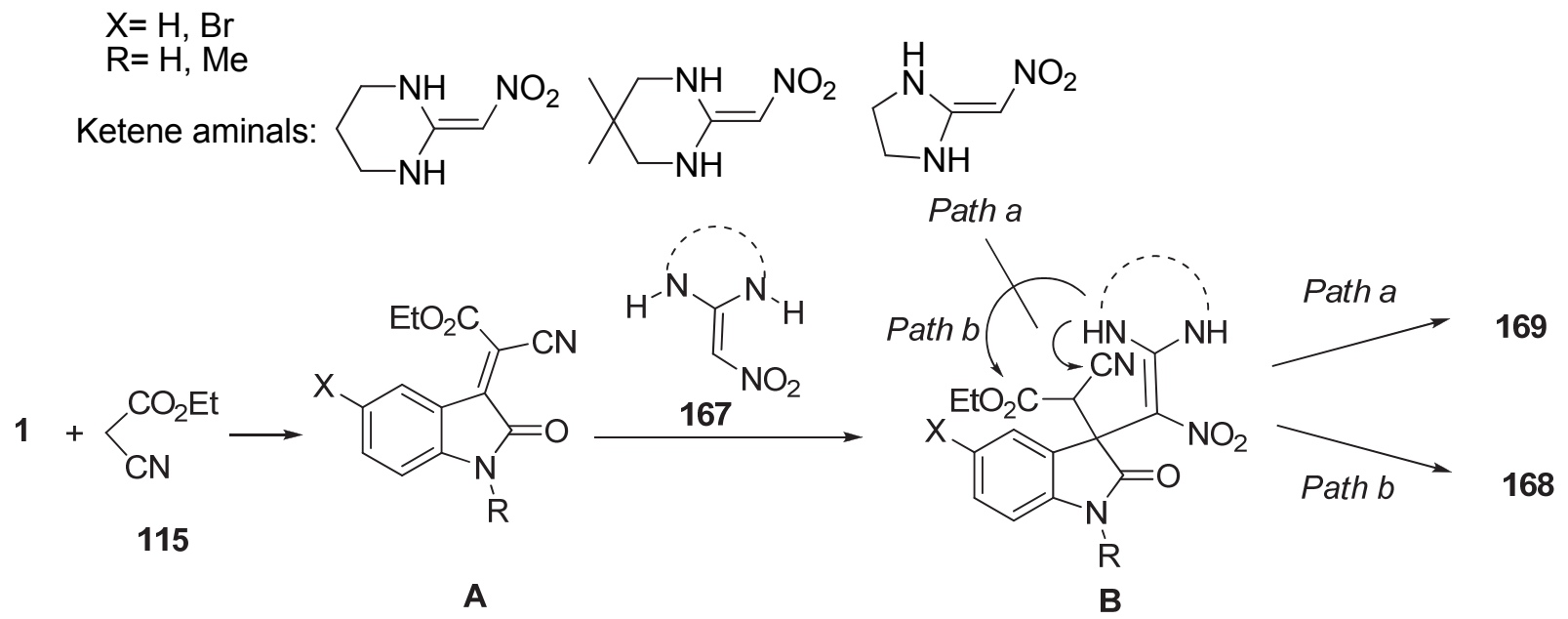

\section{Scheme 62}

Mohammadpoor-Baltork and co-workers have established novel 1'H-spiro[indoline-3,4'-

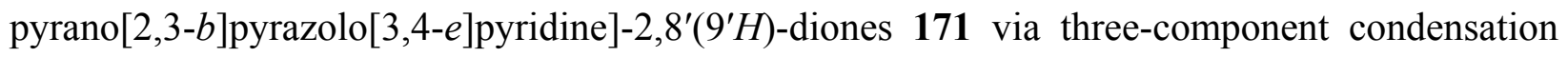
of isatin 1, 1H-pyrazol-5-amines 145, and kojic acid $\mathbf{1 7 0}$ in the presence of a catalytic amount of $\mathrm{Zn}(\mathrm{OTf})_{2}$ (Scheme 63). ${ }^{113}$

Synthesis of spiroindolinones via the reaction of barbituric acids 144, electron-rich anilines 110, and isatins 1 was carried out in ethanol in the presence of iodine as catalyst (Scheme 64). ${ }^{114}$ The $\mathrm{N}$-unsubstituted isatin fragment facilitates the rearrangement of intermediate $\mathbf{1 7 2}$ into 173 toward formation of the thermodynamically favored amide bond in spiroindolinone moiety $\mathbf{1 7 6}$. 
<smiles>[R]c1cc(N)n(-c2ccccc2)n1</smiles>

\section{Scheme 63}

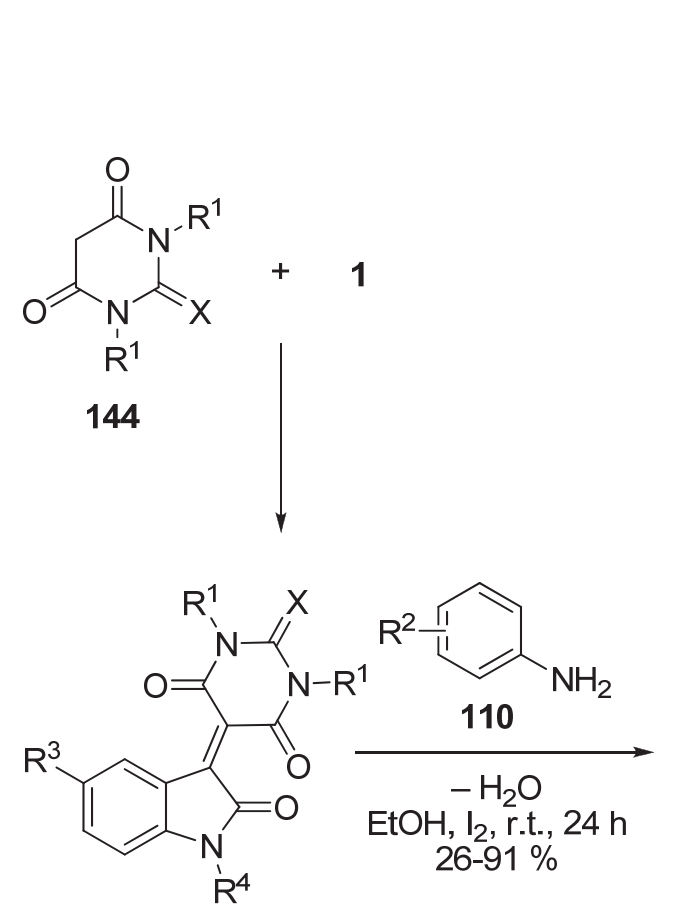

172<smiles>[R][R]1ccc2c(c1)[C@@](c1cccc([R3])c1)(C1C(=O)N([R1])C([X])N([R1])C1=O)C(=O)N2</smiles>

175

$\mathrm{R}^{4}=\mathrm{H}$<smiles>[R]Cc1ccccc1C1(C2C(=O)N([R1])C([X])N([R1])C2=O)C(=O)N([R1])c2ccc([R3])cc21</smiles>

173<smiles></smiles>

176

\footnotetext{
$\mathrm{R}^{1}=\mathrm{Me}, \mathrm{Et}, \mathrm{Pr}$

$\mathrm{R}^{2}=3,5-(\mathrm{MeO})_{2}, 3,4,5-(\mathrm{MeO})_{3}$, 2-anthraceneamine

$\mathrm{R}^{3}=\mathrm{H}, \mathrm{Cl}, \mathrm{F}, \mathrm{NO}_{2}$

$\mathrm{R}^{4}=\mathrm{H}, \mathrm{Me}, \mathrm{Et}$

$\mathrm{X}=\mathrm{O}, \mathrm{S}$
}

\section{Scheme 64}

Vilches-Herrera et al. studied the synthesis of 4-fused 4,7-dihydro-1H-pyrrolo[2,3b]pyridines 180-182 from isatins $\mathbf{1}, N$-substituted 5-amino-3-cyanopyrroles $\mathbf{1 7 7}$, and a set of 1,3- 
dicarbonyl compounds 127, 178-179 (Scheme 65). ${ }^{115}$ The reactions were carried out under mild conditions using ethanol and acetic acid as solvent.

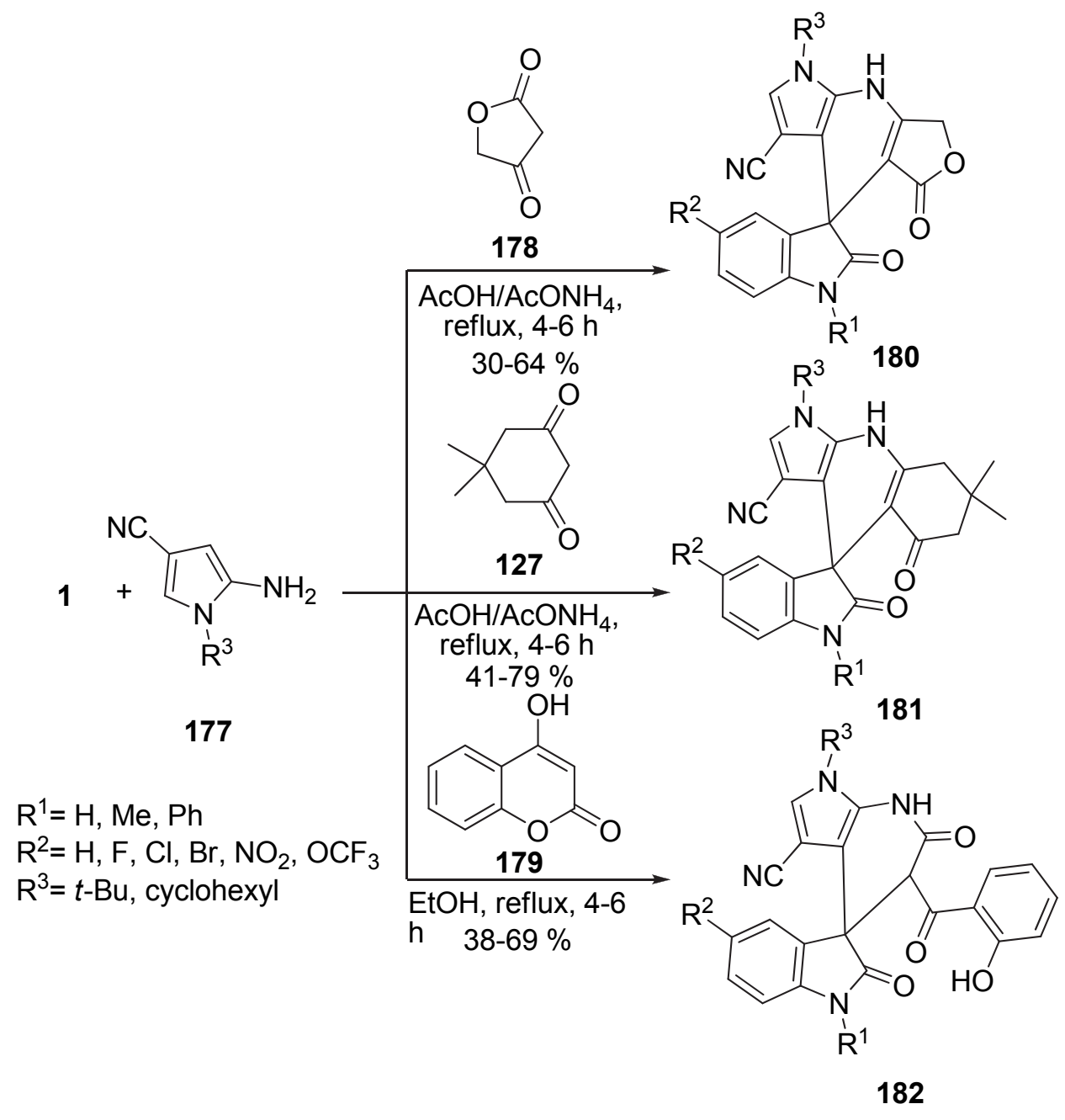

\section{Scheme 65}

In a similar way, Ghahremanzadeh and co-workers investigated three-component reaction of 2,6-diaminopyrimidine-4(3H)-one or uracils 183, isatins $\mathbf{1}$, and tetronic acid $\mathbf{1 7 8}$ in the presence of manganese ferrite nanoparticles as a magnetic catalyst in water (Scheme 66). ${ }^{116}$

Reaction of isatin derivatives 1, $2 H$-indene-1,3-dione 185, and 2-naphthalenamines 186 under catalysis of a $N, N, N^{\prime}, N^{\prime}$-tetramethylguanidinium triflate ionic liquid resulted in the formation of some fused spiro[1,4-dihydropyridine-oxindole] compounds 187 (Scheme 67). ${ }^{117}$ Application of other $\mathrm{CH}$-acids such as N,N-dimethylbarbituric acid, barbituric acid, and dimedone in this reaction was also investigated. ${ }^{118}$ 
<smiles>[R]N1C(=O)C2(C3=C(CCN3)NC3=C2C(=O)COC3=O)c2cc(C)ccc21</smiles><smiles>CO[N+]([O-])(O)O[Na]</smiles>

\section{Scheme 66}<smiles>[R]c1ccc2c(c1)C1(C(=O)N2[R2])C2=C(Nc3ccc4ccccc4c31)C(=O)c1ccccc12</smiles>

\section{Scheme 67}

Synthesis of spiro-oxindole derivatives with fused $4 H$-chromenes $\mathbf{1 8 9}$ was accomplished by condensation of isatin 1, malononitrile 115, and naphthol 188 in the presence of $L$-proline as a catalyst (Scheme 68). ${ }^{119}$ It is to be noted that the products obtained were racemic. $L$-proline did not take part in the generation of spiranic stereocenter. Hence, stereoselection was not achieved. 


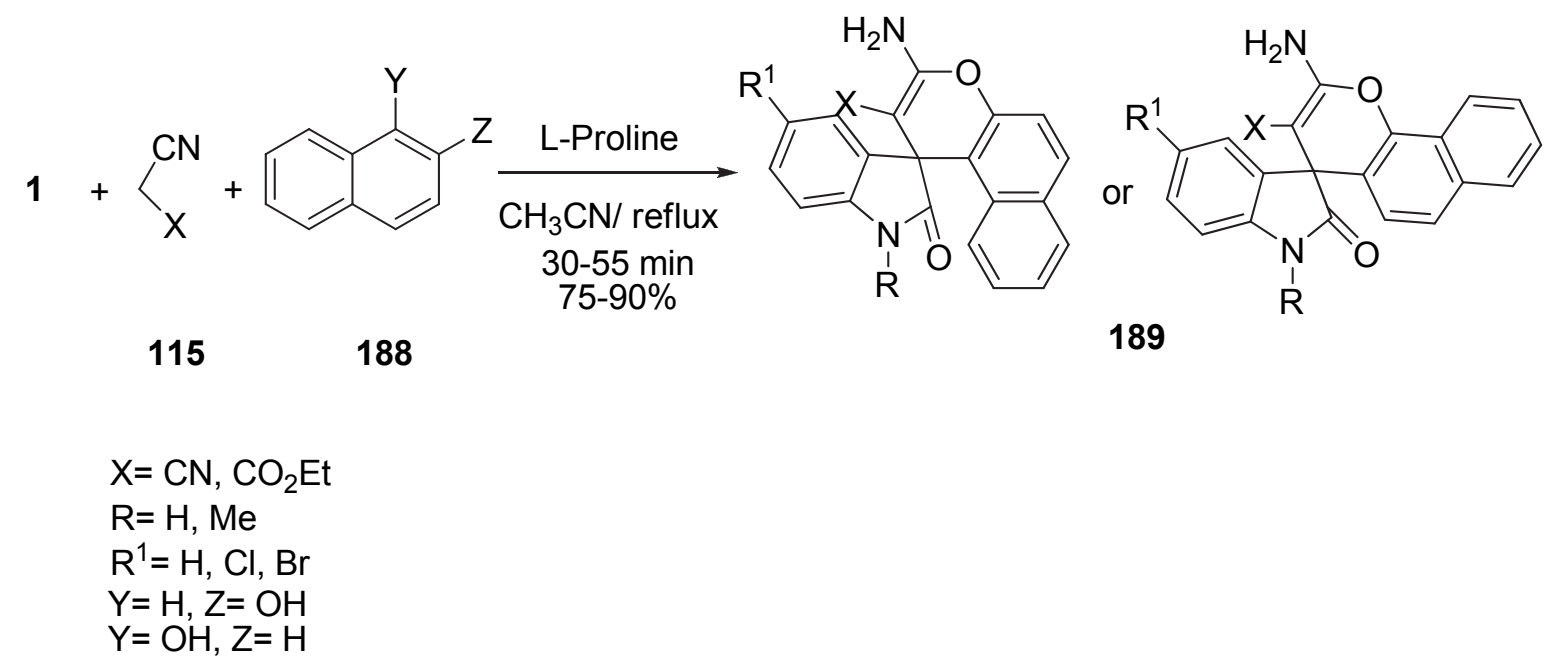

\section{Scheme 68}

New spiro[indolo-3,10'-indeno[1,2- $b$ ]quinolin]-trione derivatives 191 were successfully obtained by means of a three-component process in which enaminones 190 are treated with $\mathrm{N}$ substituted isatins 1 and indane-1,3-dione $\mathbf{1 8 5}$ in the presence of $\mathrm{FeCl}_{3}$ as the catalyst in dichloromethane at room temperature (Scheme 69). ${ }^{120}$

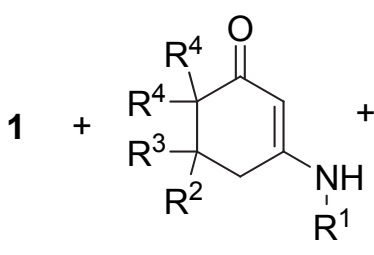

190

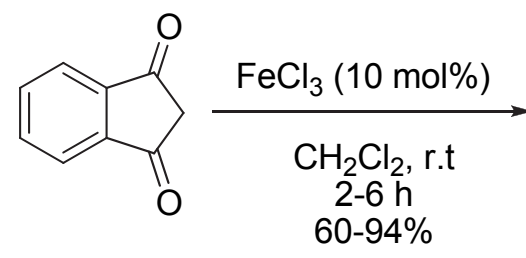

185

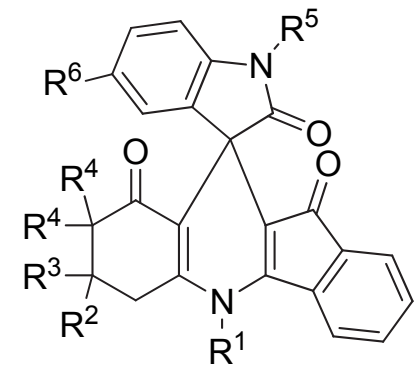

191

$$
\begin{aligned}
& \mathrm{R}^{1}=\mathrm{H}, i-\mathrm{Pr}, \mathrm{Bu}, \mathrm{Bn}, 4-\mathrm{OMeC}_{6} \mathrm{H}_{4}, 4-\mathrm{MeC}_{6} \mathrm{H}_{4}, \\
& \text { 2-i } \mathrm{PrC}_{6} \mathrm{H}_{4}, 2-\mathrm{MeC}_{6} \mathrm{H}_{4}, 3-\mathrm{MeC}_{6} \mathrm{H}_{4}, 3,4-\mathrm{Me}_{2} \mathrm{C}_{6} \mathrm{H}_{3}, \\
& \text { 3- } \mathrm{OMeC}_{6} \mathrm{H}_{4}, 4-\mathrm{ClC}_{6} \mathrm{H}_{4}, 4-\mathrm{BrC}_{6} \mathrm{H}_{4}, 2,5-\mathrm{Cl}_{2} \mathrm{C}_{6} \mathrm{H}_{3}, \\
& \text { 4- } \mathrm{CO}_{2} \mathrm{HC}_{6} \mathrm{H}_{4}, 3-\mathrm{NO}_{2} \mathrm{C}_{6} \mathrm{H}_{4} \\
& \mathrm{R}^{2}, \mathrm{R}^{3}=\mathrm{H}, \mathrm{Me}, \mathrm{Ph} \\
& \mathrm{R}^{4}=\mathrm{H}, \mathrm{Me} \\
& \mathrm{R}^{5}=\mathrm{Allyl}, \mathrm{Bn}, n-\mathrm{Bu} \\
& \mathrm{R}^{6}=\mathrm{H}, \mathrm{Cl}, \mathrm{Br}, \mathrm{NO}_{2}
\end{aligned}
$$

\section{Scheme 69}


Maiti and co-workers developed an efficient procedure for the synthesis of the functionalized dimethyl-2'-oxo-4H-spiro[benzo[f]quinoline-3,3'-indoline]-1,2-dicarboxylate derivatives 192 via one-pot three-component reactions of 2-naphthylamine 186, acetylenedicarboxylate 32, and isatin 1 catalyzed by $\mathrm{SbCl}_{3}$ in good to excellent yield (Scheme 70). ${ }^{121}$

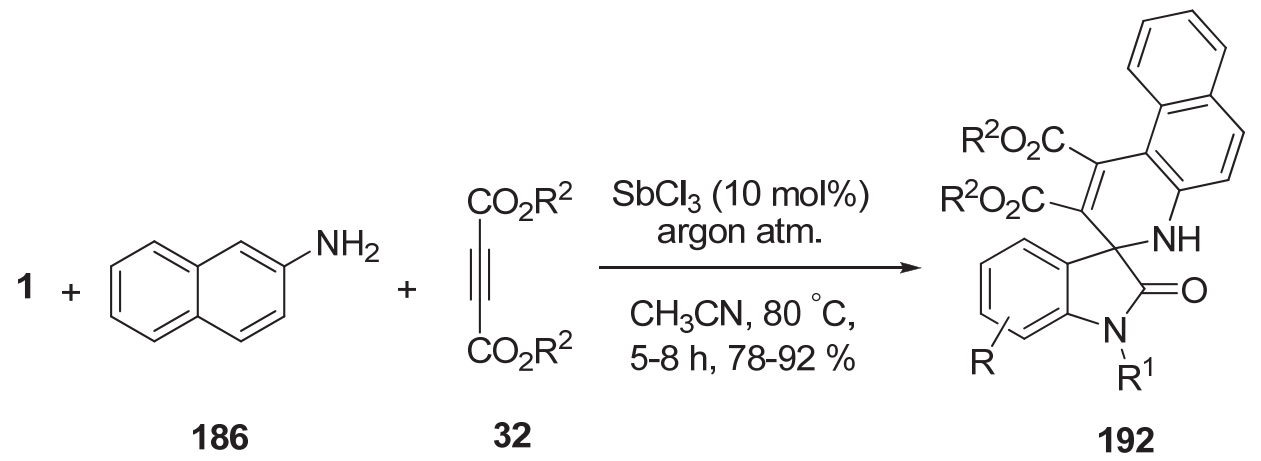

$$
\begin{aligned}
& \mathrm{R}=\mathrm{H}, 5-\mathrm{Cl}, 5-\mathrm{Br}, 5-\mathrm{I}, 7-\mathrm{Cl}, 5,7-\mathrm{Me}_{2} \\
& \mathrm{R}^{1}=\mathrm{H}, \mathrm{Me} \\
& \mathrm{R}^{2}=\mathrm{Me}, \mathrm{Et}
\end{aligned}
$$

\section{Scheme 70}

The condensation reaction of 2-hydroxynaphthalene-1,4-dione 193, pyrazol-5-amines $\mathbf{1 4 5}$, and isatins 1 in the presence of $p$-TSA afforded the spiro[11H-benzo[g]pyrazolo[4,3- $b]$ quinoline$11,3^{\prime}-[3 H]$ indole $]-2^{\prime}, 5,-10\left(1^{\prime} H\right)$-triones 194 (Scheme 71). ${ }^{122}$

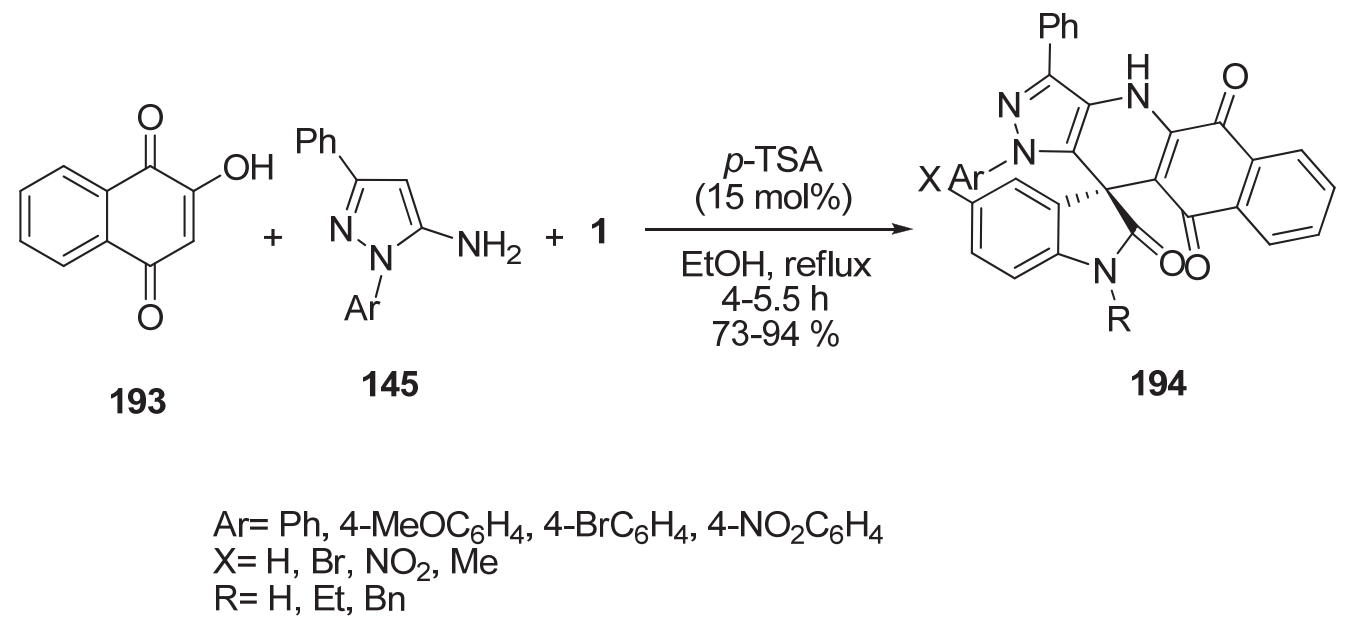

\section{Scheme 71}


Three-component cascade reaction of isatins 1, malononitrile 115, and 2-hydroxynaphthalene-1,4-diones 193 in the presence of cinchona-thiourea organocatalyst proceeded to furnish chiral pyranonaphthoquinone-fused spirooxindoles 195 in excellent yields and high enantioselectivities (Scheme 72). ${ }^{123}$<smiles>[R]c1ccc2c(c1)C(=O)C(O)=CC2=O</smiles>

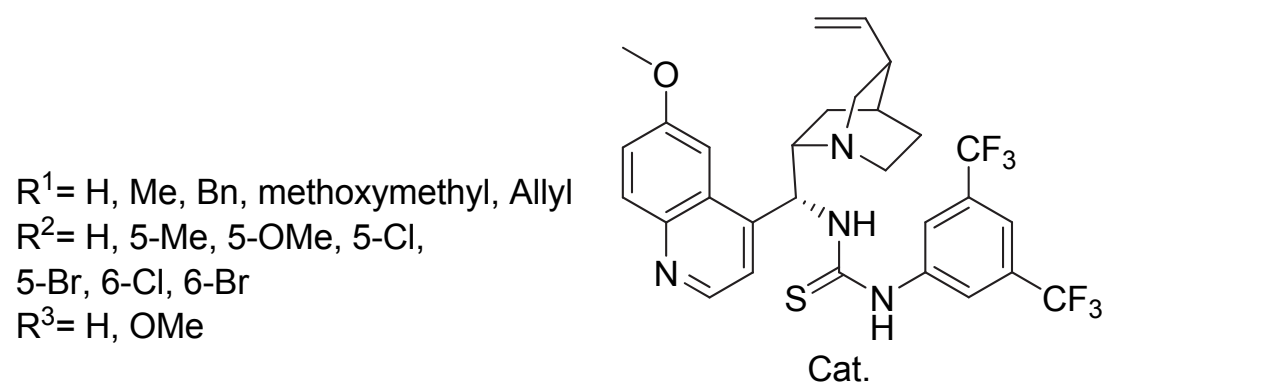

\section{Scheme 72}

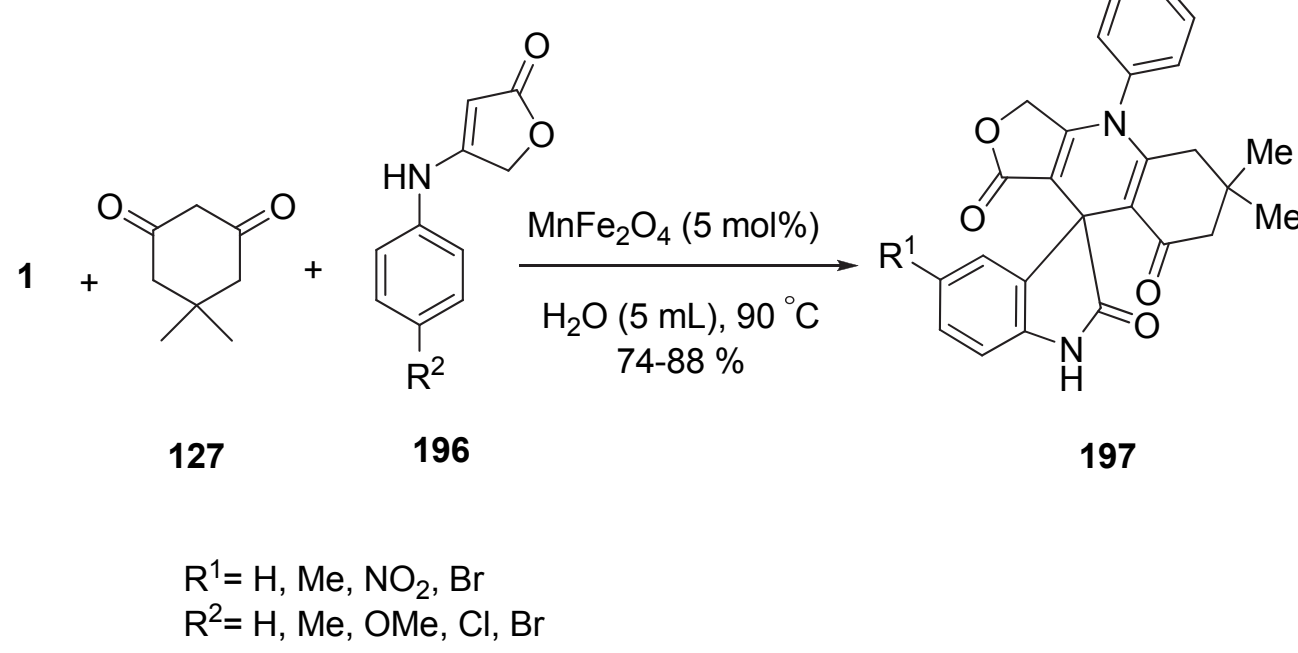

\section{Scheme 73}

4-Phenyl-6,7-dihydro-[spiro[furo]quinoline-indoline]-triones 197 were obtained via the reaction of isatins $\mathbf{1}$, dimedone $\mathbf{1 2 7}$, and anilinolactones 196 using $\mathrm{MnFe}_{2} \mathrm{O}_{4}$ nanoparticles as 
magnetically heterogeneous catalyst in water (Scheme 73). ${ }^{124}$ Replacing dimedone with malononitrile in this reaction in the presence of a catalytic amount of $\mathrm{Et}_{3} \mathrm{~N}$ as a basic catalyst in THF under ultrasound irradiation has been also reported by the same group. ${ }^{125}$

Unusual reactivity of 1-aminoanthraquinone 198 with a number of isatins 1 and aryl alkynes 199 in a copper catalyzed multicomponent reaction afforded regioisomers of 3 -spiroheterocyclic 2-oxindoles 200-201 (Scheme 74). ${ }^{126}$ Both the regioisomers exhibited considerable optical properties and found as fluorescence materials.

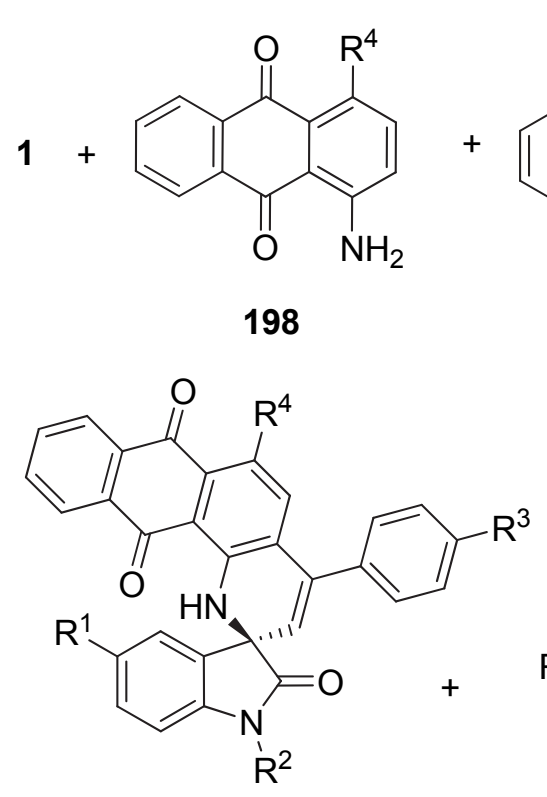

200

$33-42 \%$

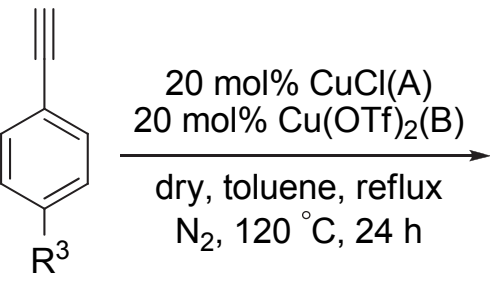

199<smiles>[R]c1ccc(C2=C[C@]3(C(=O)N([R])c4ccc([R])cc43)c3cc([R4])c4c(c3N2)C(=O)c2ccccc2C4=O)cc1</smiles>

201

$$
\begin{aligned}
& \mathrm{R}^{1}=\mathrm{H}, \mathrm{NO}_{2}, \mathrm{Me}, \mathrm{I}, \mathrm{OCF}_{3}, \mathrm{Br} \\
& \mathrm{R}^{2}=\mathrm{Me}, \mathrm{H} \\
& \mathrm{R}^{3}=\mathrm{H}, \mathrm{Me}, \mathrm{F}, \mathrm{OCH}_{3}, \mathrm{CF}_{3}, \mathrm{NH}_{2} \\
& \mathrm{R}^{4}=\mathrm{H}, \mathrm{NH}_{2}
\end{aligned}
$$

\section{Scheme 74}

The $p$-toluenesulfonic acid catalyzed Povarov reaction of isatin-3-imines 120 with $\beta$ enamino esters, which were generated in situ by the reaction of arylamines $\mathbf{1 1 0}$ and methyl propiolate 36 in ethanol, afforded the polysubstituted spiro[indoline-3,2'-quinolines] 202 in high yields and with high diastereoselectivity (Scheme 75 ). ${ }^{127}$ 


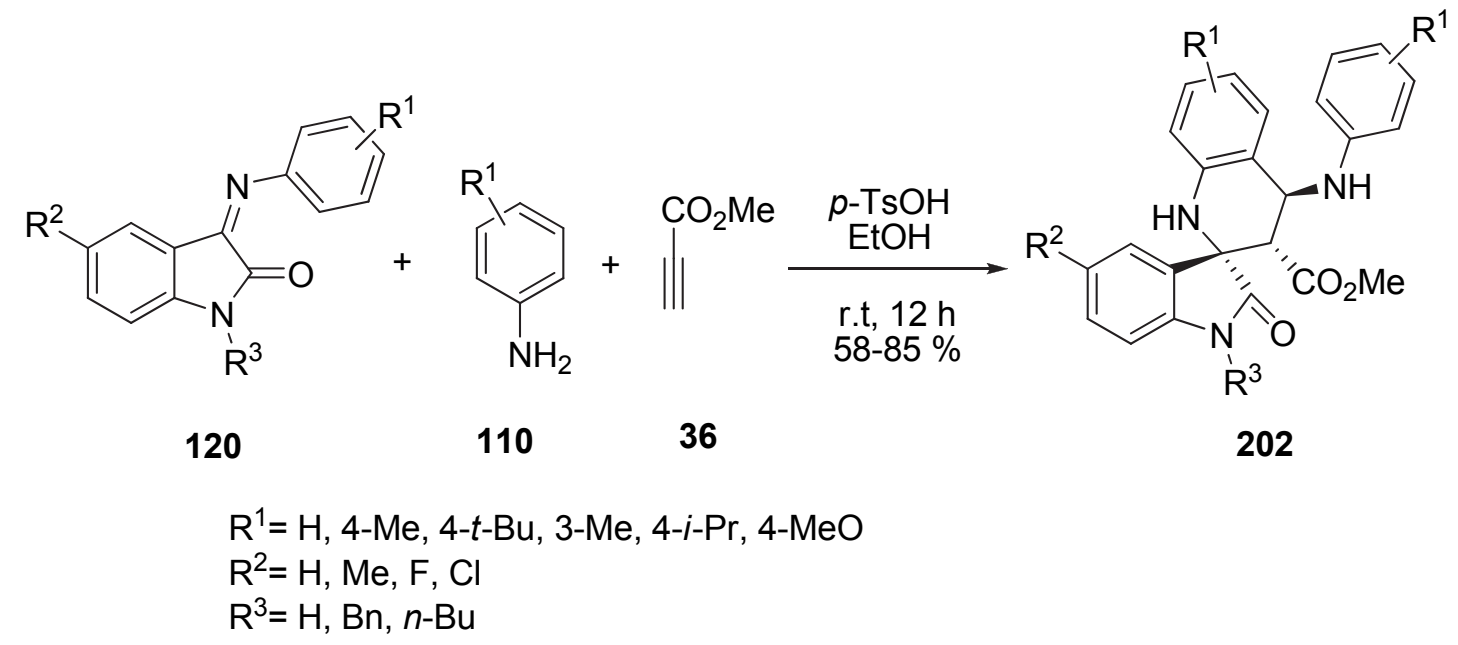

\section{Scheme 75}

Meshram's group reported a method for the synthesis of spiro[quinazoline/pyrimidine]ones scaffold 204-205 by the reaction of isatin 1, 1,3-dione 185/144 and urea or guanidine compounds 203 (Scheme 76). ${ }^{128}$ In another study Baghernejad and Khorshidi established the reaction between isatin, urea and 1,3-dicarbonyl compounds for the preparation of spirooxindoles in the presence of nano- $\mathrm{ZnO}$ as a catalyst. ${ }^{129}$

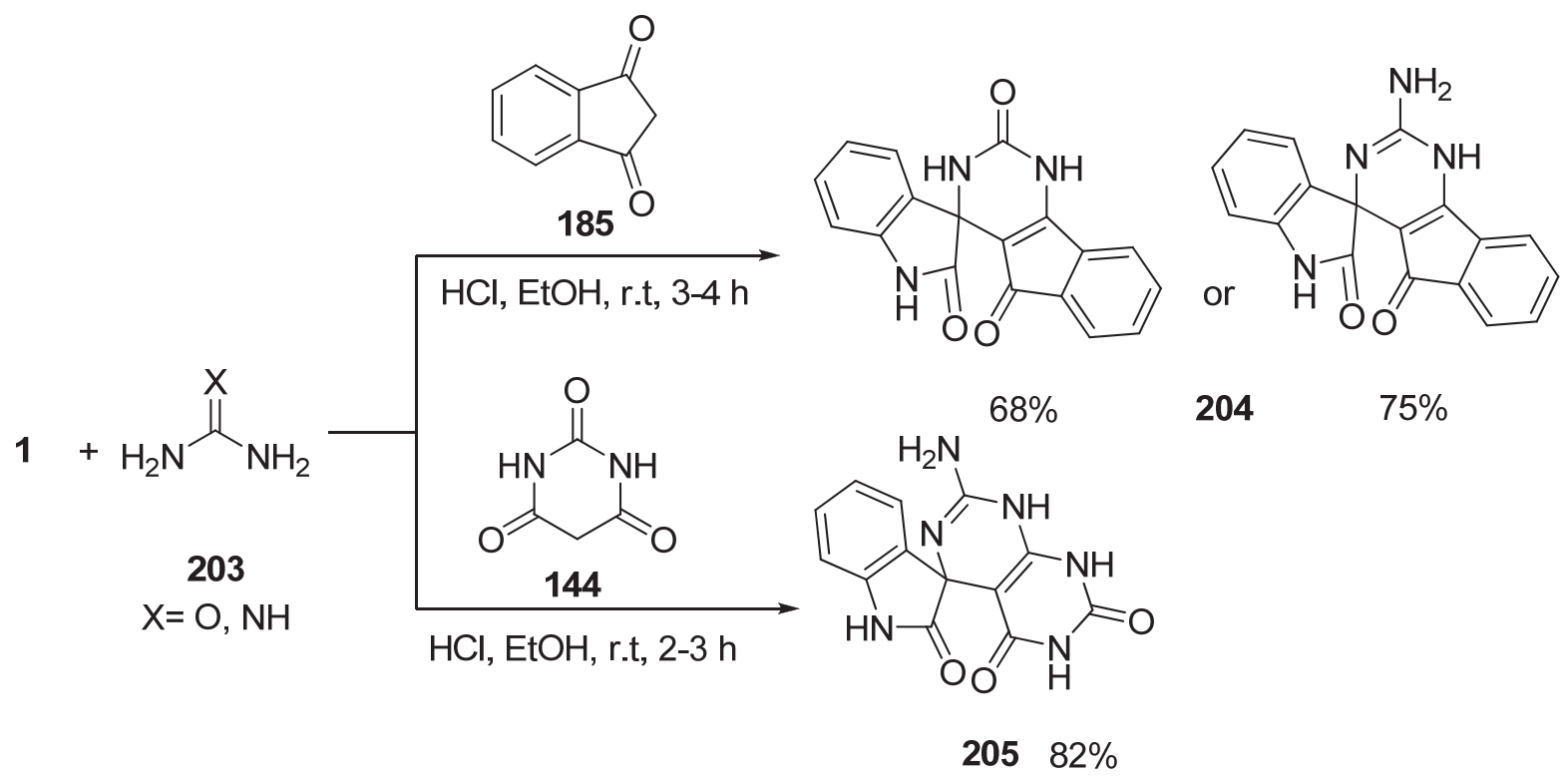

\section{Scheme 76}

An organocatalytic cascade reaction involving a Michael-aldol-acetalization relay to achieve the asymmetric assembly of aldehydes 206, nitroolefins 69, and isatins 1 into six- 
membered oxa-spirooxindole backbones 207 with high diastereo- and enantioselectivity was developed by Xie et al. (Scheme 77). ${ }^{130}$

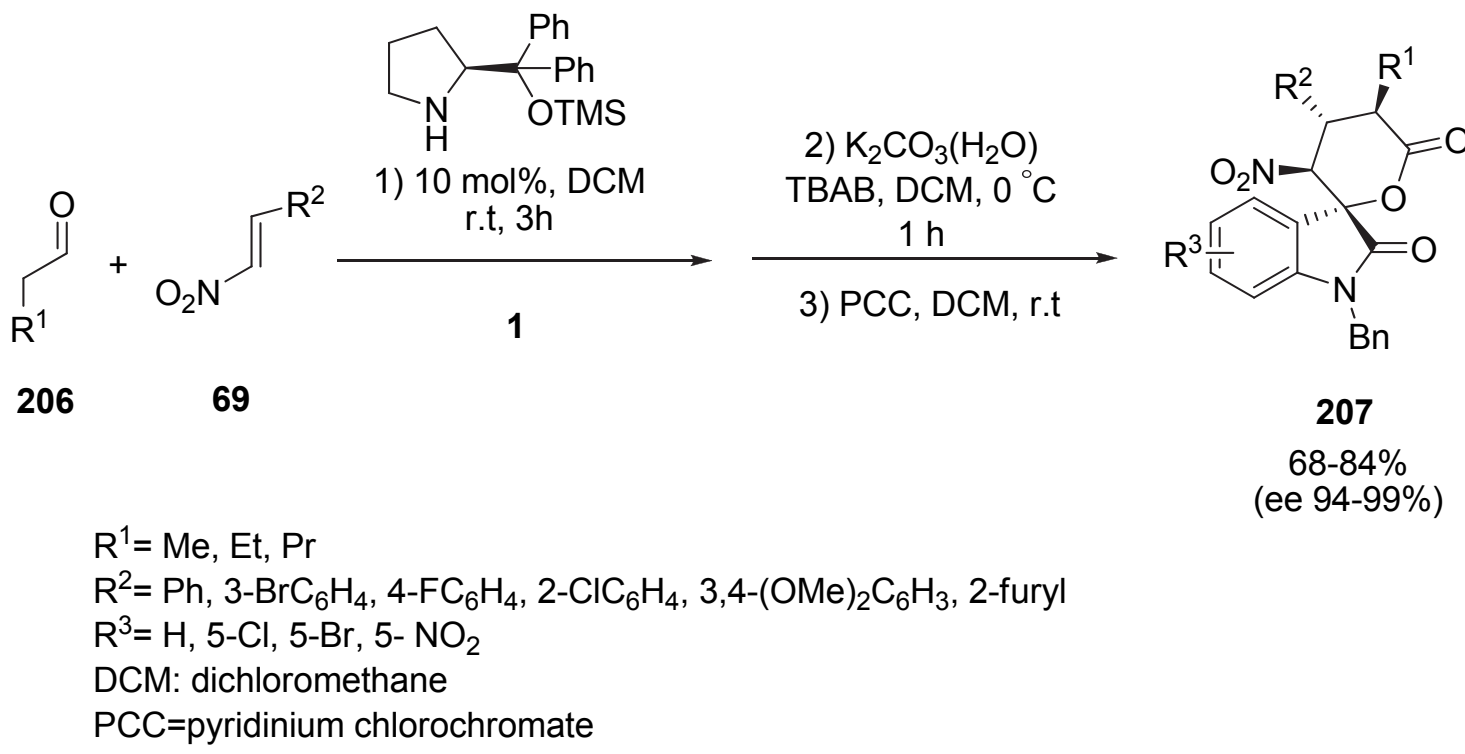

\section{Scheme 77}

$[1,3]$ Oxazino[2,3-a] isoquinoline derivatives $\mathbf{2 0 9}$ were prepared from isoquinoline 208 , allenoates 41, and isatin derivatives 1 via 1,4-dipolar cycloaddition reaction (Scheme 78). ${ }^{131}$ The $\mathrm{X}$-ray diffraction showed that products were synthesized in moderate diastereoselectivities.
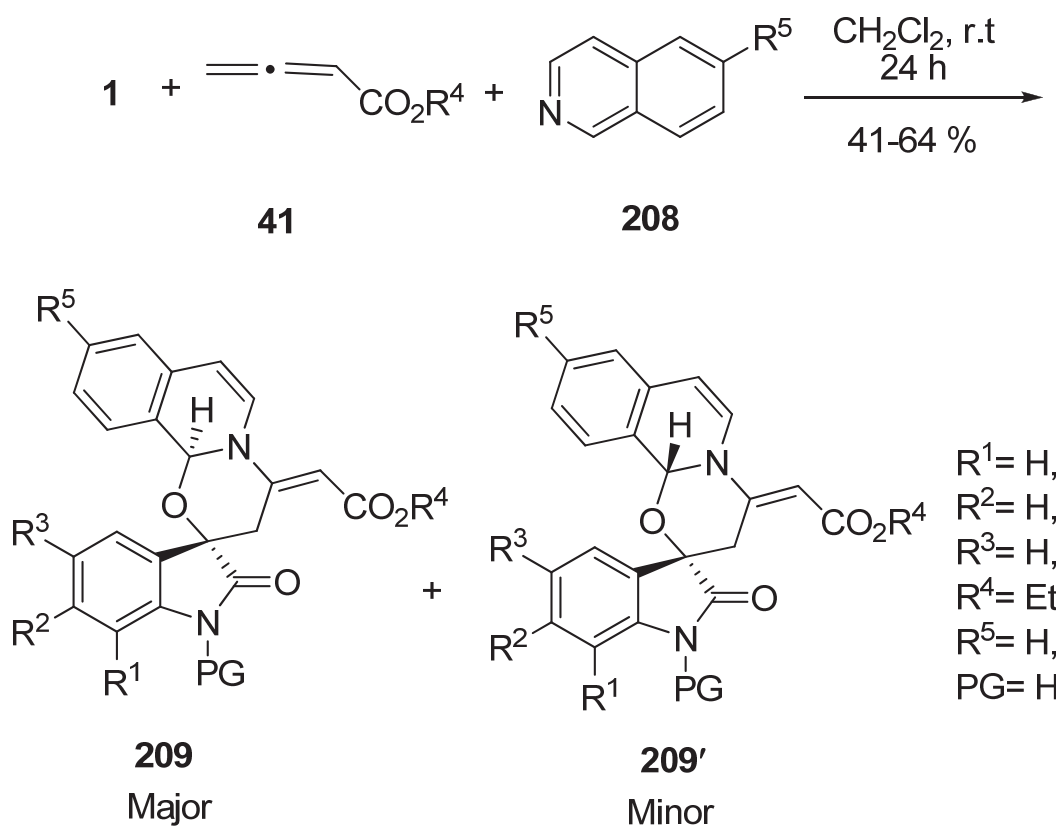

$\mathrm{R}^{1}=\mathrm{H}, \mathrm{Br}, \mathrm{Me}$

$\mathrm{R}^{2}=\mathrm{H}, \mathrm{Br}, \mathrm{Me}$

$\mathrm{R}^{3}=\mathrm{H}, \mathrm{Me}, \mathrm{Cl}, \mathrm{Br}$

$\mathrm{R}^{4}=\mathrm{Et}, \mathrm{Bn}$

$\mathrm{R}^{5}=\mathrm{H}, \mathrm{Cl}$

$P G=H, B n$

\section{Scheme 78}


Reaction of isatin 1 with $p$-substituted phenols 210 in the presence of $p$-TsOH as catalyst in refluxing $p$-xylene, afforded 3,3-bis-(2-hydroxy-5-alkylphenyl)oxindoles $(\mathbf{2 1 1}, \mathbf{2 1 2})$ and their in situ conversion into 2',7'-dialkylspiro[indoline-3,9'-xanthen]-2-ones (213, 214, 215) (Scheme 79). ${ }^{132}$

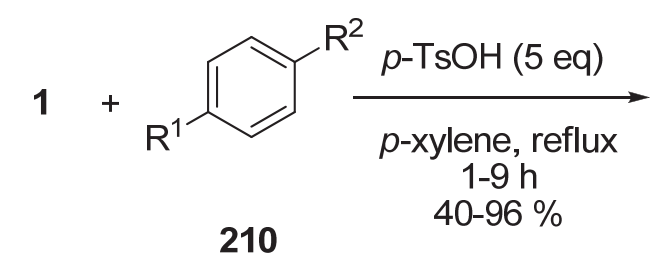

$1 \mathrm{eq}$

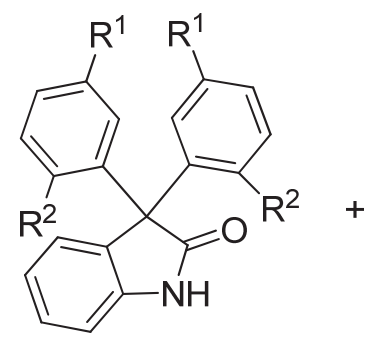

211

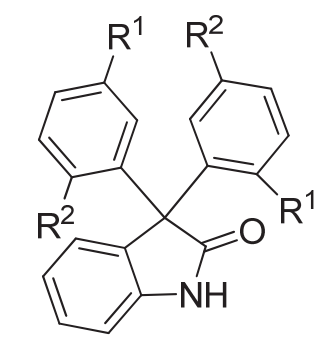

212<smiles>[R]c1ccc2c(c1)C1(C(=O)N2)c2cc([R])ccc2Oc2ccc([R])cc2C2(C(=O)Nc3ccccc32)c2cc([R])ccc21</smiles>

$$
\begin{aligned}
& \mathrm{R}^{1}=t \text {-Bu, } n-\mathrm{Bu}, i-\mathrm{Pr}, \mathrm{Ph}, \mathrm{Me}, \\
& \mathrm{OH}, \mathrm{OMe}, \mathrm{O}-n-\mathrm{Bu}, \mathrm{OPh}, c-\text { Pentyl } \\
& \mathrm{R}^{2}=\mathrm{H}, \mathrm{OH}
\end{aligned}
$$

\section{Scheme 79}

Mohammadi Ziarani and co-workers carried out a method for the synthesis of spiro[indoline-3,9'-xanthene]trione derivatives $\mathbf{2 1 6}$ through the condensation reaction of isatins $\mathbf{1}$ and two moles of dimedone or 1,3-cyclohexanedione $\mathbf{1 2 7}$ under solvent-free conditions in the presence of SBA-15-Pr- $\mathrm{SO}_{3} \mathrm{H}$ as a heterogeneous nano catalyst (Scheme 80). ${ }^{133}$ 


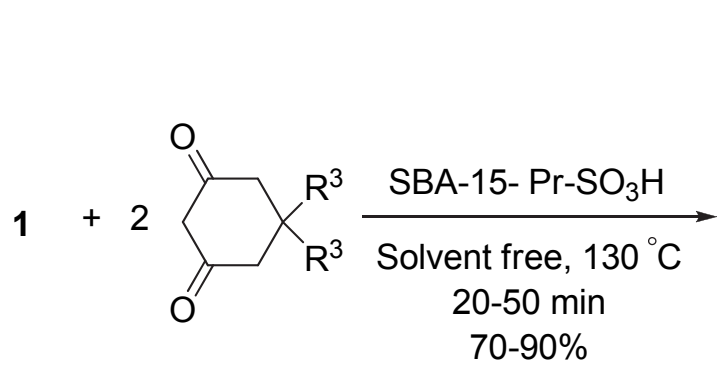

127

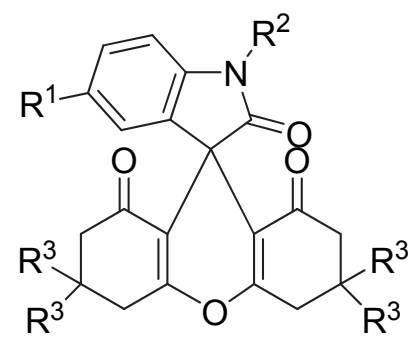

216

$$
\begin{aligned}
& \mathrm{R}^{1}=\mathrm{H}, \mathrm{Cl}, \mathrm{Br}, \mathrm{NO}_{2} \\
& \mathrm{R}^{2}=\mathrm{H}, \mathrm{Me} \\
& \mathrm{R}^{3}=\mathrm{H}, \mathrm{Me}
\end{aligned}
$$

\section{Scheme 80}

Rahmati et al. prepared the spirooxindole scaffold by the reaction of isatin $\mathbf{1}$ with activated pyrazolones 217 in the presence of a catalytic amount of $p$-toluenesulfonic acid (Scheme 81). ${ }^{134}$ A variety of symmetrical spirooxindole derivatives $\mathbf{2 1 8}$ were obtained with excellent yields within short reaction time.

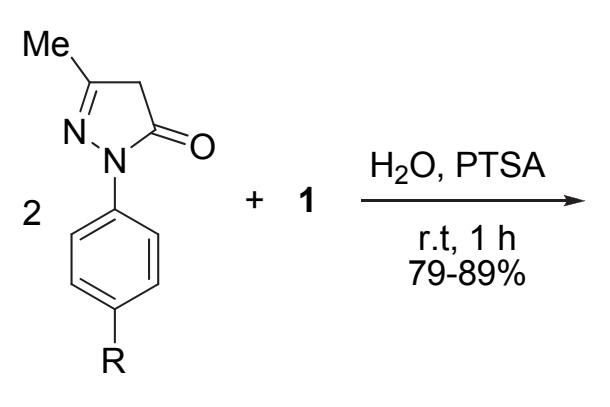

217

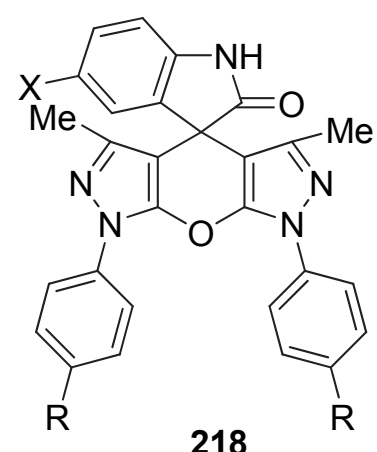

218

$$
\begin{aligned}
& \mathrm{X}=\mathrm{Cl}, \mathrm{Br}, \mathrm{Me}, \mathrm{OMe}, \mathrm{NO}_{2} \\
& \mathrm{R}=\mathrm{H} \text { or } \quad \stackrel{\mathrm{O}}{\mathrm{S}}-\mathrm{NH}_{2} \\
& \mathrm{O}
\end{aligned}
$$

\section{Scheme 81}

The reaction of substituted isatins 1 , barbituric acids 144, and cyclohexane-1,3-diones 127 for the direct construction of a library of spirooxindole-pyrimidine derivatives 219 was catalyzed by nano magnetically silica-supported dodecyl benzenesulfonic acid $\left(\gamma-\mathrm{Fe}_{2} \mathrm{O}_{3} @ \mathrm{SiO}_{2}\right.$-DDBSA) in water (Scheme 82). ${ }^{135}$ This reaction was also accomplished in the presence of alum $\left(\mathrm{KAl}\left(\mathrm{SO}_{4}\right)_{2} \cdot 12 \mathrm{H}_{2} \mathrm{O}\right)^{136}$ and gluconic acid aqueous solution (GAAS) as catalysts. ${ }^{137}$ 


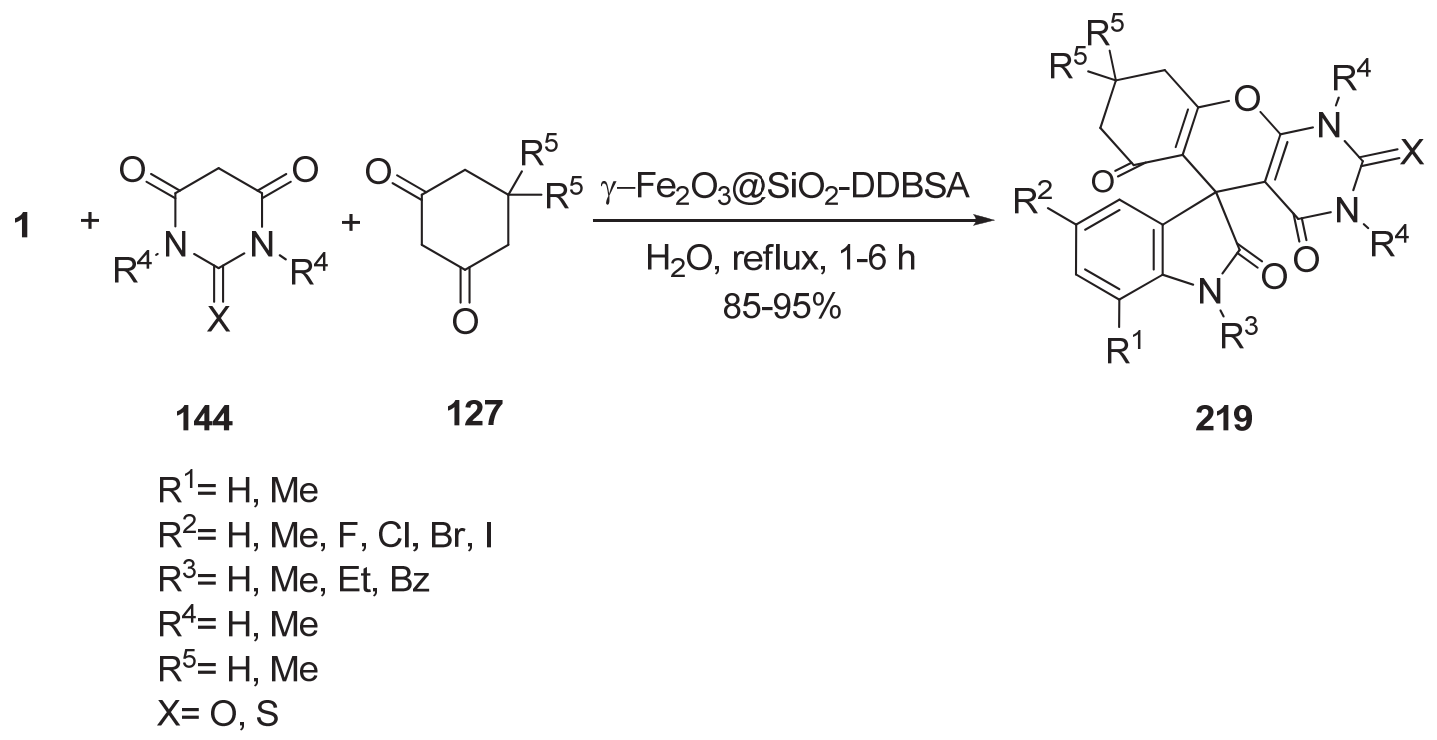

\section{Scheme 82}

A green one-pot synthesis of spironaphthopyrano[2,3- $d$ ]pyrimidine-5,3'-indoline derivatives 220 by a three-component reaction of isatins 1, 2-naphthol 188, and barbituric acids 144 under solvent-free conditions in the presence of $\mathrm{SBA}-\mathrm{Pr}-\mathrm{SO}_{3} \mathrm{H}$ has been accomplished (Scheme 83). ${ }^{138}$ Replacement of barbituric acid with 1,3-indanedione in this reaction leads to the synthesis of spironaphthopyrano[1,2- $b]$ indeno-7,3'-indolines. ${ }^{139}$<smiles>[R]N1C(=O)CC(=O)N([R])C1=O</smiles>

144<smiles>Oc1ccc2ccccc2c1</smiles>

188

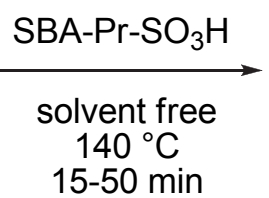

$15-50 \mathrm{~min}$<smiles></smiles>

220

$$
\begin{aligned}
& \mathrm{R}^{1}=\mathrm{H}, \mathrm{Me} \\
& \mathrm{R}^{2}=\mathrm{H}, \mathrm{Me} \\
& \mathrm{X}=\mathrm{Cl}, \mathrm{Br}, \mathrm{NO}_{2}
\end{aligned}
$$

\section{Scheme 83}

Paul and Das applied PEG-OSO ${ }_{3} \mathrm{H}$ as a catalyst in reactions involving the domino coupling of 1,3-diketo compounds 127, 144, 185, 6-aminouracil 183/4-aminocoumarin 221, and isatins 1 for the synthesis of uracil $\mathbf{2 2 2}$ and coumarin $\mathbf{2 2 3}$ fused spirooxindole derivatives, respectively. (Scheme 84). ${ }^{140}$ 


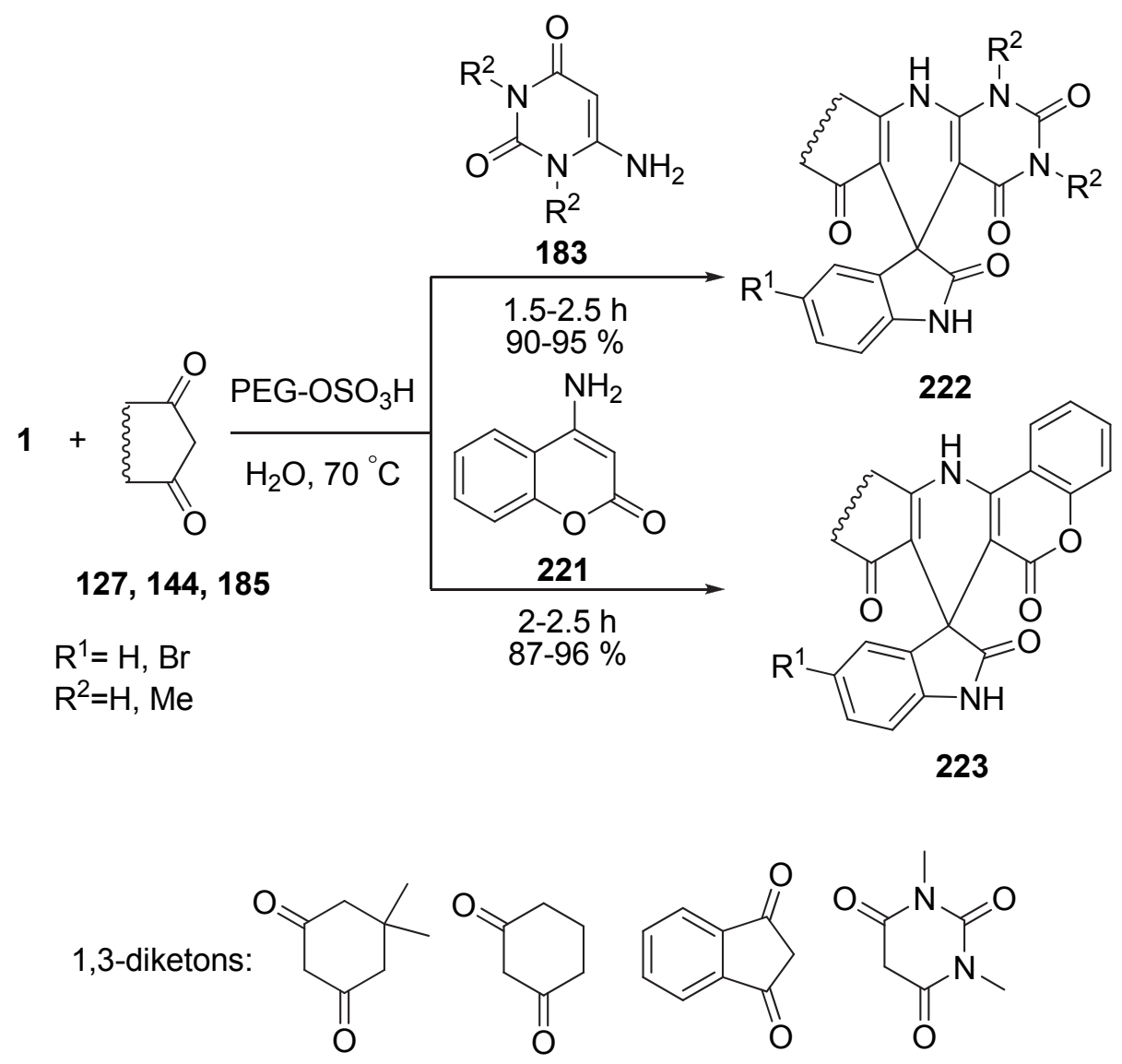

\section{Scheme 84}

A $p$-toluenesulfonic acid-catalyzed three-component reaction of isatins $\mathbf{1}$, aminouracils $\mathbf{1 8 3}$, and isoxazolones $\mathbf{2 2 4}$ as coupling partners for the synthesis of spiroxindole derivatives $\mathbf{2 2 5}$ was reported by Perumal and co-workers (Scheme 85). ${ }^{141}$

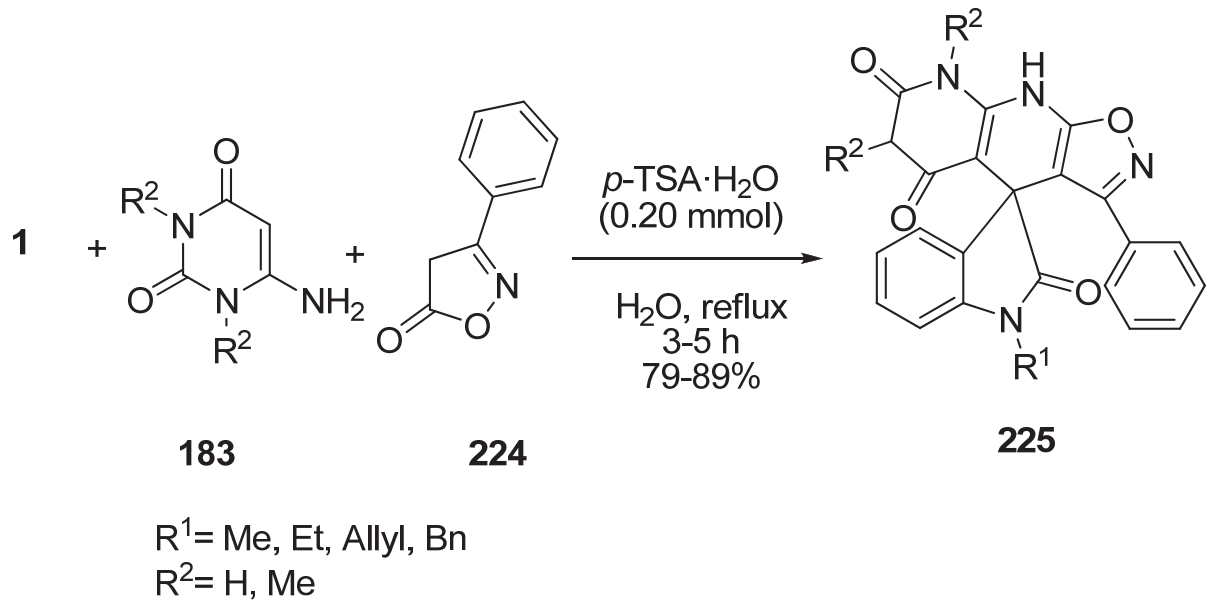

\section{Scheme 85}


The synthesis of spirochromene derivatives 226-227 was carried out using isatins 1, malononitrile 115, and cyclic 1,3-diketones 127/4-hydroxycoumarin $\mathbf{1 7 9}$ as a model substrate in the presence of gold(III) chloride $\left(\mathrm{HAuCl}_{4} \cdot 3 \mathrm{H}_{2} \mathrm{O}\right)$ as catalyst in PEG (Scheme 86). ${ }^{142}$ Moreover, silica-bonded 5- $n$-propyl-octahydro-pyrimido[1,2-a]azepinium chloride (SB-DBU)C, ${ }^{143}$ DBU in water, ${ }^{144} \mathrm{Mg}\left(\mathrm{ClO}_{4}\right)_{2},{ }^{145} \mathrm{DABCO},{ }^{146}\left[\gamma-\mathrm{Fe}_{2} \mathrm{O}_{3} @ \mathrm{HAp}-\mathrm{Si}\left(\mathrm{CH}_{2}\right)_{3} \mathrm{SO}_{3} \mathrm{H}\right],{ }^{147}$ SBA-Pr-SO $\mathrm{H}_{3},{ }^{148-149}$ SBA-Pr-NH $2,{ }^{150,151}$ SBA-15@DABCO $,{ }^{152} \mathrm{CaCl}_{2},{ }^{153}$ PEG-Ni nanoparticle, ${ }^{154}$ triphenylphosphine $\left(\mathrm{PPh}_{3}\right),{ }^{155}$ mesoporous silica nanoparticles $(\mathrm{MSNs}),{ }^{156}$ nanocrystalline $\mathrm{MgO}$ in aqueous condition, ${ }^{157}$ glycerol-based carbon-sulfonic acid, ${ }^{158} \alpha$-amylase, ${ }^{159}$ and hexamethylenetetramine (HMT) in water ${ }^{160}$ were also used as catalyst in this reaction. Kidwai and co-workers analyzed these compounds for their cytotoxic activity against U87 human glioma cells. ${ }^{161} \mathrm{Wu}$ et al. used an aqueous media without any catalysts under microwave irradiation. ${ }^{162}$ In another study, glycerol as a biodegradable and reusable promoting medium was applied under catalyst-free conditions. ${ }^{163}$ This reaction was also conducted under catalyst-free condition in deep eutectic solvent (DES based choline chloride) ${ }^{164}$ or under catalyst-free conditions in DMSO at $70{ }^{\circ} \mathrm{C} .{ }^{165}$ Elinson's group reported thermal non-catalytic reaction in water or alcohols in high yields. ${ }^{166} \mathrm{~A}$ similar reaction has been reported by Zakeri and co-workers under microwave irradiation in the presence of 4-dimethylaminopyridine (DMAP). ${ }^{167}$

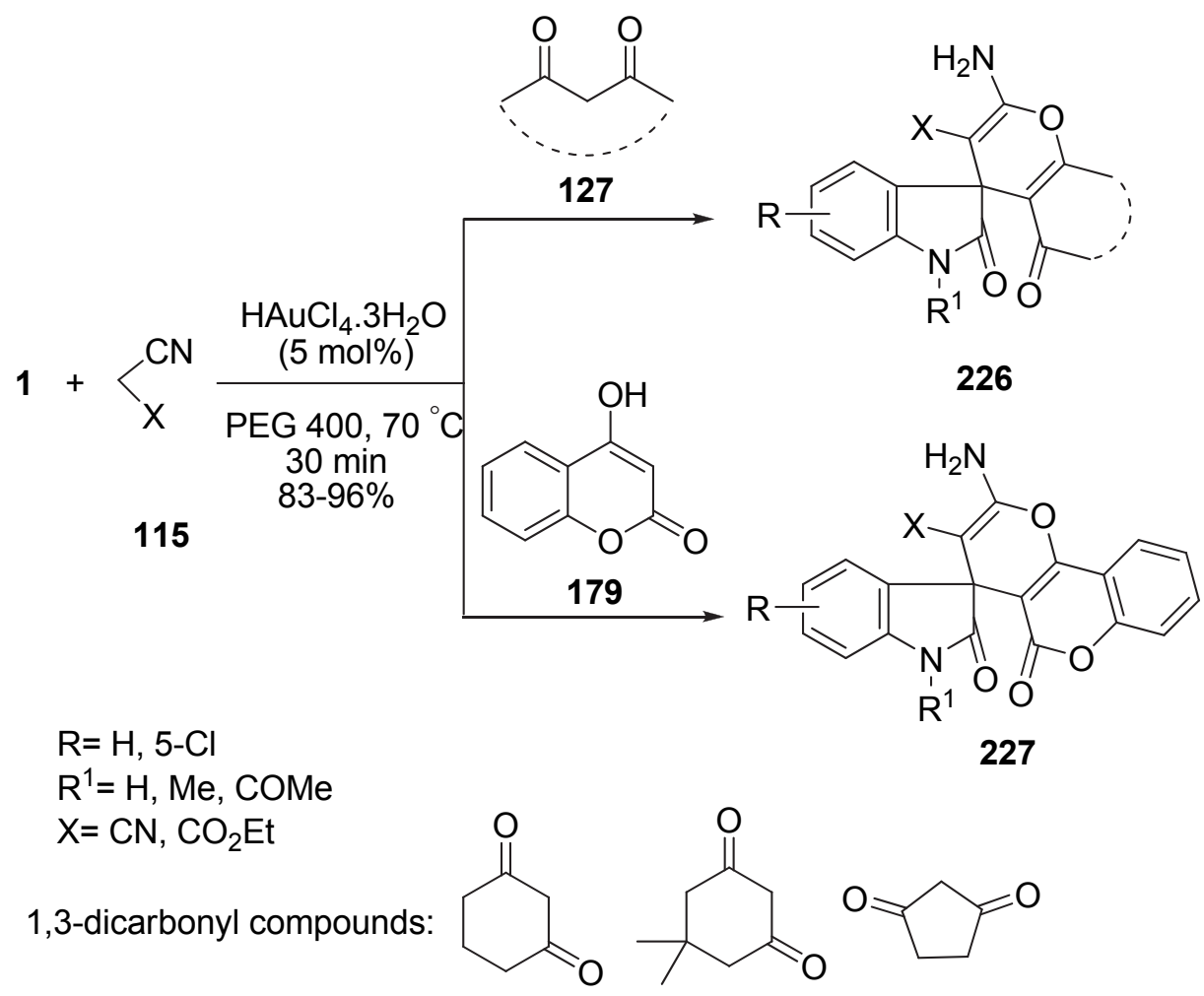

\section{Scheme 86}


Lee and co-workers made a series of novel 2-amino-5-hydroxy-4H-chromene derivatives 229 with a spirooxindole nucleus using $\mathrm{Ca}(\mathrm{OH})_{2}$-mediated three-component reactions of substituted resorcinols 228 with isatins 1 and malononitrile 115 (Scheme 87). ${ }^{168}$

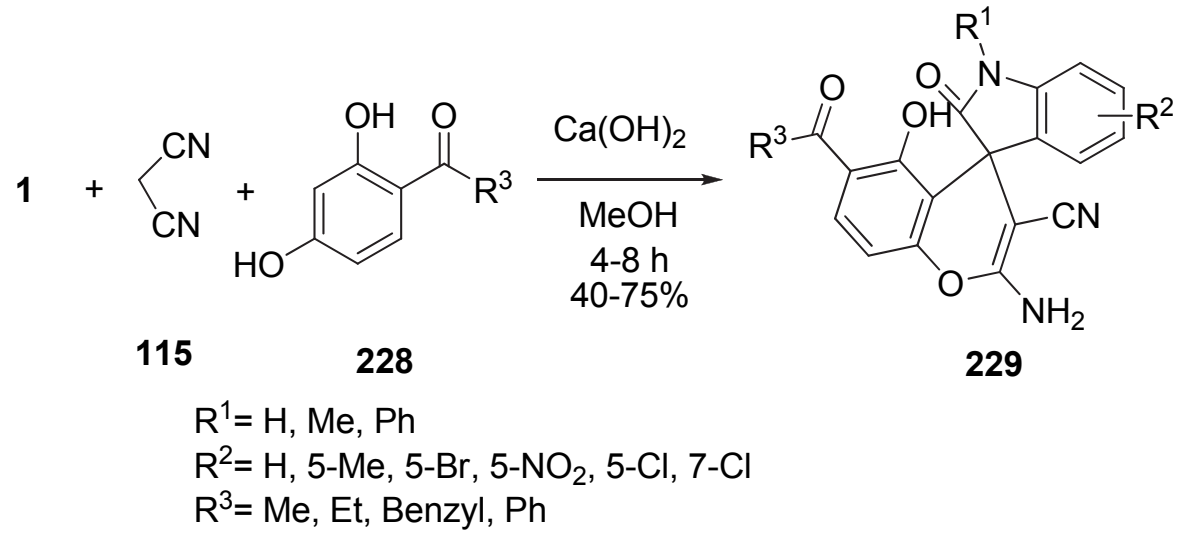

\section{Scheme 87}

Synthesis of pyranocoumarin fused spirooxindole derivatives 231 from the one-pot threecomponent reaction of isatin $\mathbf{1}$, malononitrile 115, and 5,7-dihydroxy-4-methyl- $2 H$-chromen-2one 230 using piperidine as organocatalyst has been reported by Choudhury and co-workers (Scheme 88). ${ }^{169}$ When ethyl cyanoacetate was employed in the reaction instead of malononitrile, transesterified product was formed in methanol.

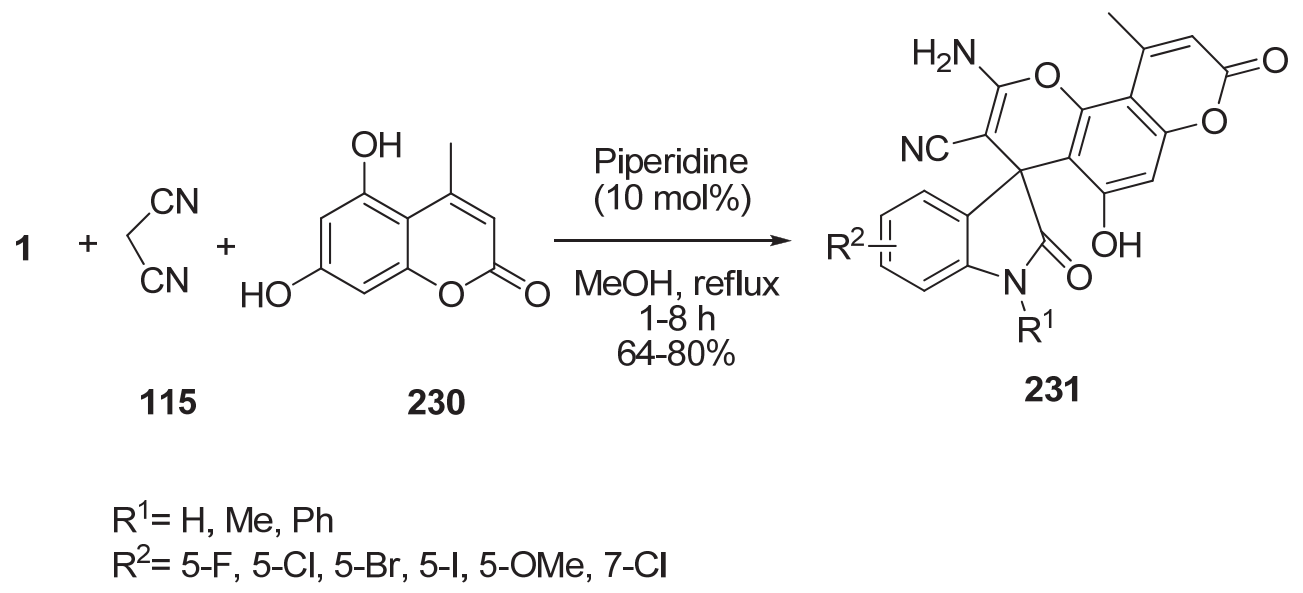

\section{Scheme 88}

Perumal's group used the $\mathrm{Cu}(\mathrm{OTf})_{2}$ as catalyst for synthesis of spiropyrano[3,2-b]pyran4(8H)-ones 232 in the reaction between isatin 1, kojic acid 170, and active methylenes 115 (Scheme 89). ${ }^{170}$ Synthesized compounds were evaluated for their tumor cell growth inhibitory 
activity against the human lung cancer cell line (A549). Later, application of catalytic amount of DABCO in this reaction was also investigated. ${ }^{171}$

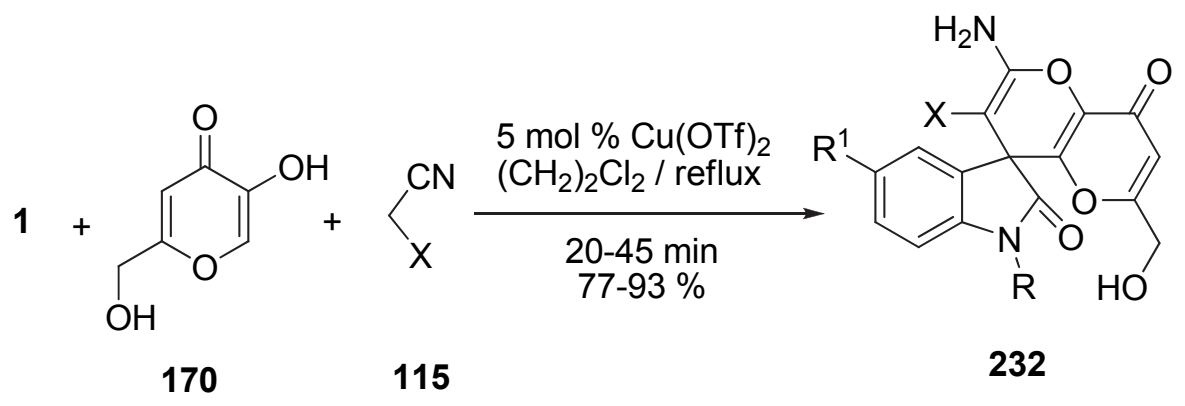

$$
\begin{aligned}
& \mathrm{R}=\mathrm{H}, \mathrm{Me}, \text { Allyl, Bn, Propargyl } \\
& \mathrm{R}^{1}=\mathrm{H}, \mathrm{F}, \mathrm{Cl}, \mathrm{Br}, \mathrm{Me}, \mathrm{NO}_{2} \\
& \mathrm{X}=\mathrm{CN}, \mathrm{CO}_{2} \mathrm{Me}, \mathrm{CO}_{2} \mathrm{Et}
\end{aligned}
$$

\section{Scheme 89}

Efficient synthesis of novel triazolylspiroxindolinopyrans 234 was achieved by reacting phenacyltriazole 233, isatin $\mathbf{1}$, and active methylene compounds 115 in the presence of $\mathrm{InCl}_{3}$ under solvent-free conditions at $100{ }^{\circ} \mathrm{C}$ (Scheme 90). ${ }^{172}$

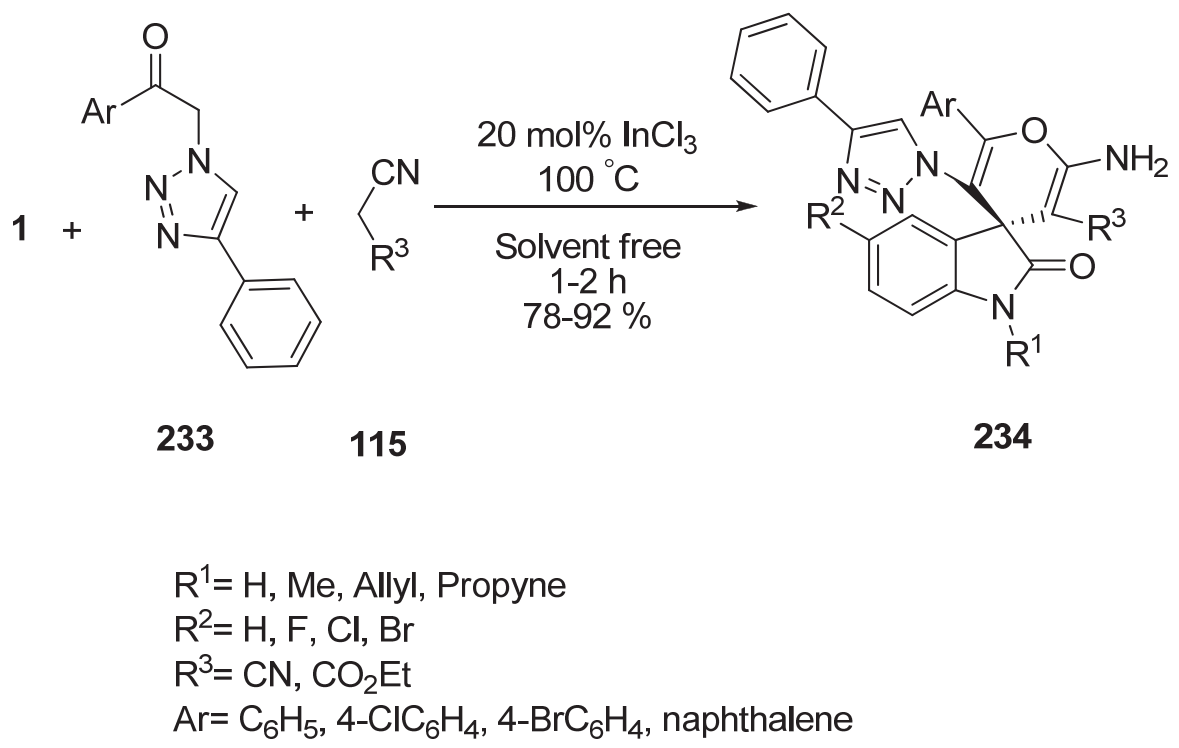

\section{Scheme 90}

A series of spiro-2-amino-3-phenylsulfonyl-4H-pyran derivatives 236 were synthesized via the reaction of phenylsulfonylacetonitrile 235 and 1,3-dicarbonyl compounds with isatins $\mathbf{1}$ using 
a novel basic ionic liquid 2-hydroxyethylammonium acetate $\left[\mathrm{H}_{3} \mathrm{~N}^{+} \mathrm{CH}_{2} \mathrm{CH}_{2} \mathrm{OH}\right]\left[\mathrm{CH}_{3} \mathrm{COO}^{-}\right]$ (HEAA) as catalyst (Scheme 91). ${ }^{173}$

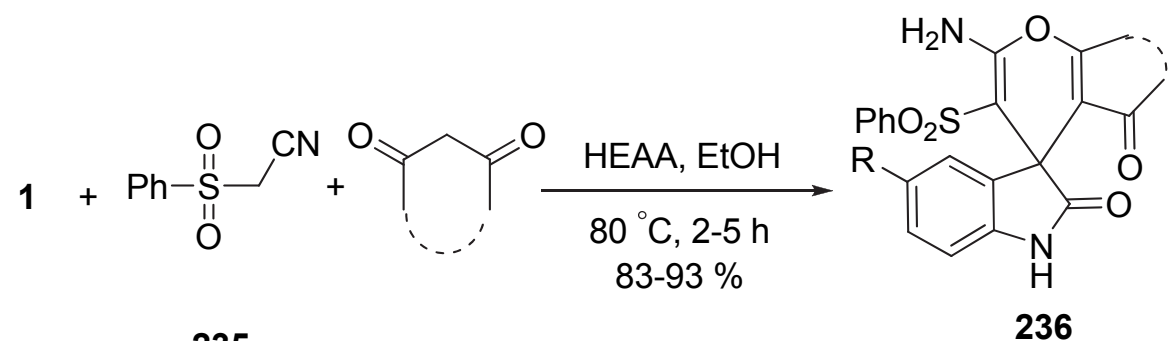

235<smiles>[R]OC(=O)CC(C)=O</smiles>

\section{Scheme 91}

Bazgir and co-workers reported a method for the synthesis of polyfunctionalized pyranofused spirooxindoles 237 via the condensation of isatins 1, malononitrile 115, and dialkyl acetylenedicarboxylates 32 in the presence of 3,4-dimethylaniline (DMA) as an organocatalyst (Scheme 92). ${ }^{174}$

$$
\begin{aligned}
& 1+\angle C+\left.\right|_{C N} ^{C N} \frac{\substack{\text { r.t, } 8 \mathrm{~h} \\
76-93 \%}}{\mathrm{CO}_{2} \mathrm{R}^{2}} \\
& 115 \quad 32 \\
& 237 \\
& \mathrm{X}=\mathrm{H}, \mathrm{Br}, \mathrm{NO}_{2} \\
& \mathrm{R}=\mathrm{H}, \mathrm{Me}, \mathrm{CH}_{2} \mathrm{Ph} \\
& \mathrm{R}^{1}=\mathrm{H}, \mathrm{Me}, \mathrm{Et}, \mathrm{Bu} \\
& \mathrm{R}^{2}=\mathrm{Me}, \mathrm{Et}, \mathrm{Bu}
\end{aligned}
$$

\section{Scheme 92}


The one-pot Knoevenagel condensation/Michael addition/cyclization reaction of indoline-2thiones 238, isatin derivatives $\mathbf{1}$, and malononitriles $\mathbf{1 1 5}$ afforded the spirooxindole-annulated thiopyran derivatives 239 (Scheme 93). ${ }^{175}$

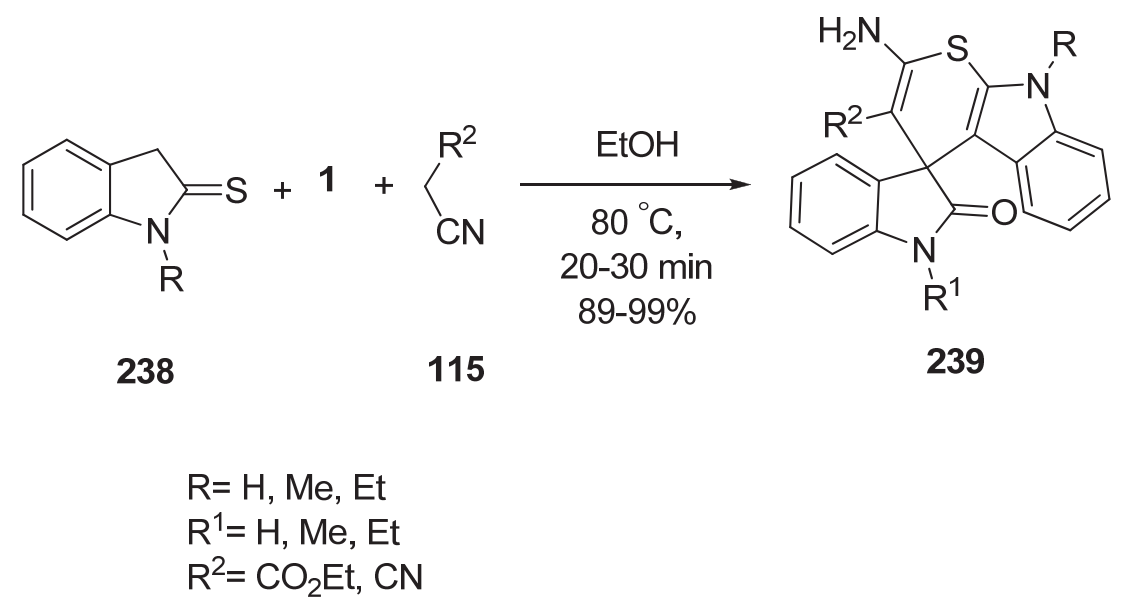

\section{Scheme 93}

Regioselective synthesis of structurally diverse spirooxindole-fused phosphorus heterocycle derivatives 242 and 242' was constructed by means of a three-component domino reaction of isatins 1, dichlorophenylphosphine or phenyl phosphorodichloridite 241, and $o$-aminophenol 240 in tetrahydrofuran reflux (Scheme 94). ${ }^{176}$

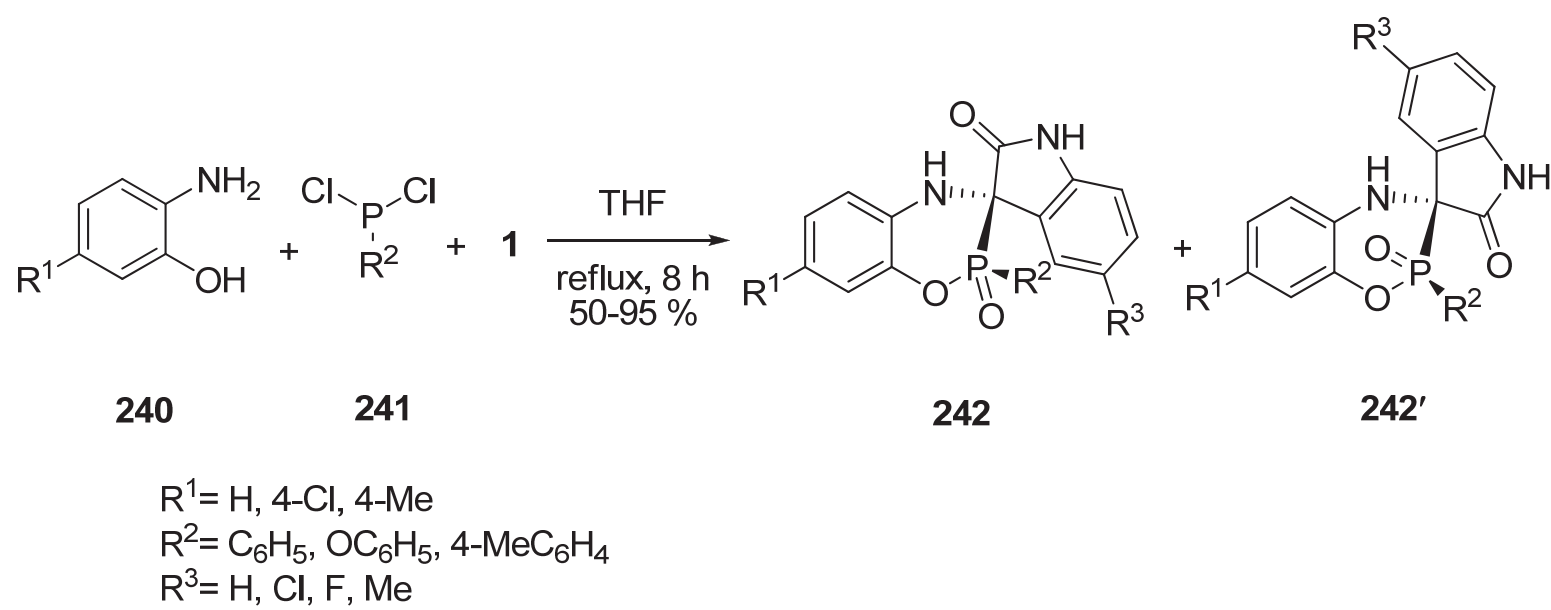

\section{Scheme 94}

\subsection{Synthesis involving four-component reactions of isatins}

2.2.1. Five-membered spiro-fused compounds. A series of novel dispiropyrrolidine-linked 1,2,3-triazole derivatives $\mathbf{2 4 5}$ have been prepared by one-pot, four-component protocol that employed 5-arylidene-3-(prop-2-ynyl)thiazolidine-2,4-dione 243, isatin 1, sarcosine 9, and 
substituted azides 244 using $\mathrm{Cu}(\mathrm{I})$ generated in situ as catalyst in PEG-400 as a highly efficient and green medium (Scheme 95). ${ }^{177}$

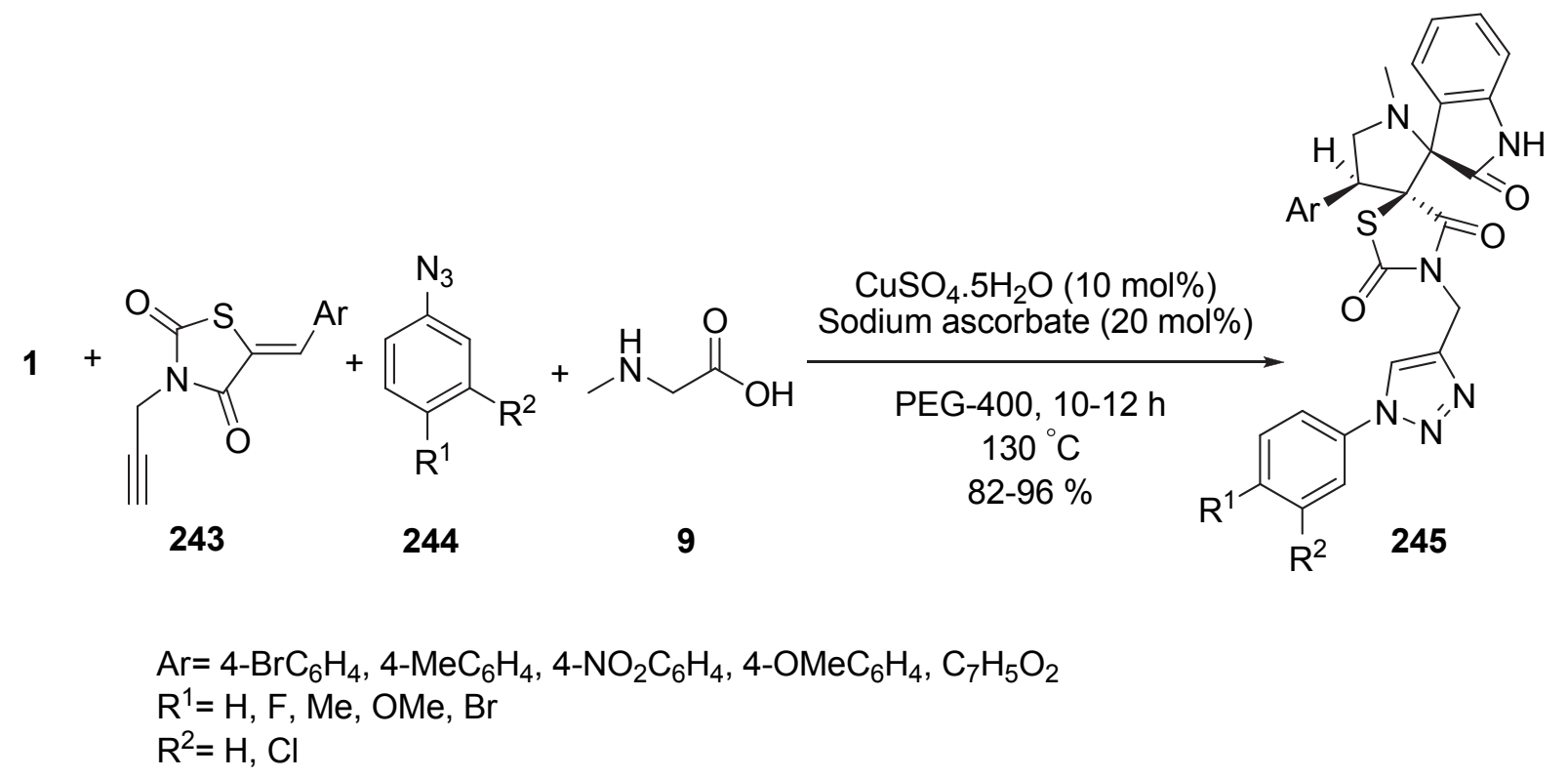

\section{Scheme 95}

The one-pot synthesis of a series of novel spiropyrano[2,3- $d][1,3]$ thiazolo $[3,2-a]$ pyrimidine derivatives $\mathbf{2 4 7}$ was achieved via the sequential reaction of 4-aryl-octahydro-pyrano[2,3d]pyrimidine-2-thione 246, dimethyl acetylenedicarboxylate 32, and a mixture of isatin 1 and sarcosine 9 (Scheme 96). ${ }^{178}$<smiles>[Al]C1NC(=S)NC2OC[CH+]CCC12</smiles>

246<smiles>COCC#CC(=O)OC</smiles>

32<smiles>COC(=O)C1CN(C)CC12SC1=NC3OCCCC3C([Al])N1C2=O</smiles>

247

$\mathrm{Ar}=4-\mathrm{ClC}_{6} \mathrm{H}_{4}, 4-\mathrm{OMeC}_{6} \mathrm{H}_{4}, 2,4-\mathrm{Cl}_{2} \mathrm{C}_{6} \mathrm{H}_{3}$, 3,4,5-(MeO) $)_{3} \mathrm{C}_{6} \mathrm{H}_{2}, 4-\mathrm{FC}_{6} \mathrm{H}_{4}, 4-\mathrm{SMeC}_{6} \mathrm{H}_{4}$, 4- $\mathrm{MeC}_{6} \mathrm{H}_{4}, 4-\mathrm{CO}_{2} \mathrm{MeC}_{6} \mathrm{H}_{4}, \mathrm{C}_{6} \mathrm{H}_{5}$

\section{Scheme 96}

2.2.2. Six-membered spiro-fused compounds. Ghahremanzadeh and co-workers developed a four-component reaction between isatins 1 , barbituric acids 144, phenyl hydrazines 130, and 
phenacyl cyanide 248 in the presence of alum $\left[\mathrm{KAl}\left(\mathrm{SO}_{4}\right)_{2} \cdot 12 \mathrm{H}_{2} \mathrm{O}\right]$ as catalyst using the ionic liquid $[\mathrm{Bmim}] \mathrm{PF}_{6}$ as an effective green reaction medium (Scheme 97). ${ }^{179}$<smiles>[R]N1C(=O)CC(=O)N([R])C1=[V]</smiles>

144<smiles>[X]c1ccc(NN)cc1</smiles>

130

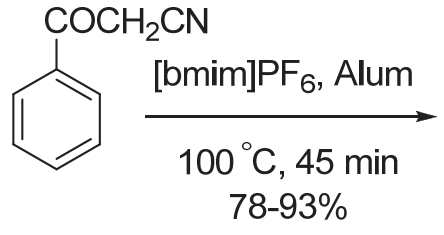

248

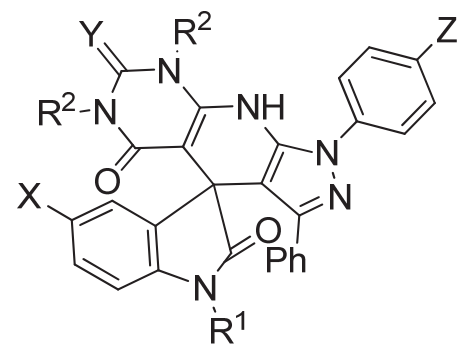

249

$$
\begin{aligned}
& \mathrm{R}^{1}=\mathrm{H}, \mathrm{Me}, \mathrm{Et} \\
& \mathrm{R}^{2}=\mathrm{H}, \mathrm{Me} \\
& \mathrm{X}=\mathrm{H}, \mathrm{Br}, \mathrm{NO}_{2}, \mathrm{Me} \\
& \mathrm{Y}=\mathrm{O}, \mathrm{S} \\
& \mathrm{Z}=\mathrm{H}, \mathrm{NO}_{2}
\end{aligned}
$$

\section{Scheme 97}

Structurally diverse benzothiazolylquinoline-2,5-diones $\mathbf{2 5 2}$ were synthesized by a synthetic method involving sulfamic acid catalyzed one-pot four-component reaction of Meldrum's acid 250, 2-aminobenzothiazoles 251, dimedone 127, and isatin 1 (Scheme 98). ${ }^{180}$ Replacing Meldrum's acid with barbituric acid in this reaction using $\mathrm{SO}_{3} \mathrm{H}$-functionlized halogen-free ionic liquid 3-methyl-1-(butyl-4-sulfonyl)imidazolium hydrogen sulphate ([MIM( $\left.\left.\left(\mathrm{CH}_{2}\right)_{4} \mathrm{SO}_{3} \mathrm{H}\right]\left[\mathrm{HSO}_{4}\right]\right)$ in aqueous medium was also reported by the same group. ${ }^{181}$<smiles>Cc1cc(Br)cc2sc(N)nc12</smiles>

\section{Scheme 98}


Yan's group developed a synthetic procedure for the synthesis of spiro[indoline-3,4'pyridine] derivatives $\mathbf{2 5 3}$ via the four-component reaction of arylamines 110, acetylenedicarboxylates 32, isatins 1 and malononitrile $\mathbf{1 1 5}$ in the presence of triethylamine as the base catalyst (Scheme 99). ${ }^{182}$

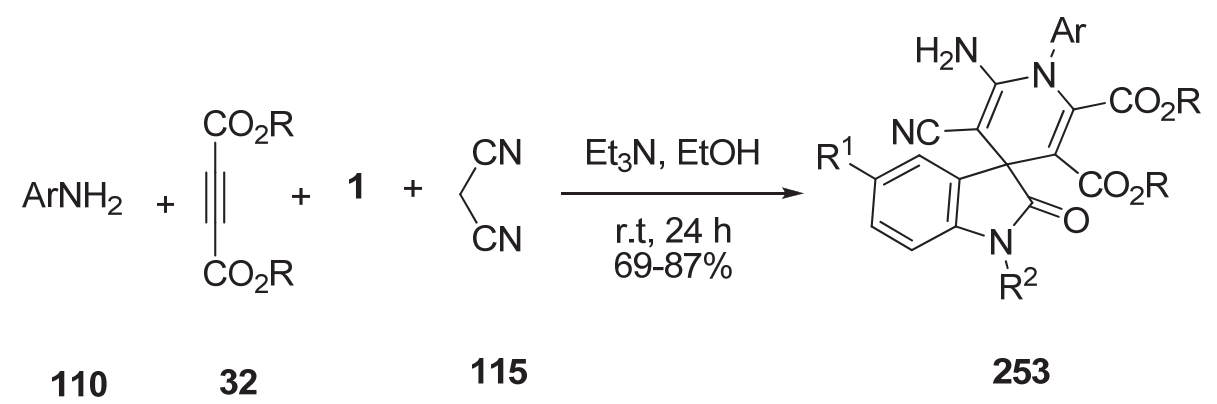

$\mathrm{Ar}=p-\mathrm{MeC}_{6} \mathrm{H}_{4}, p-\mathrm{MeOC}_{6} \mathrm{H}_{4}, p-\mathrm{ClC}_{6} \mathrm{H}_{4}, p-\mathrm{NO}_{2} \mathrm{C}_{6} \mathrm{H}_{4}, m-\mathrm{NO}_{2} \mathrm{C}_{6} \mathrm{H}_{4}$

$\mathrm{R}=\mathrm{Me}, \mathrm{Et}$

$\mathrm{R}^{1}=\mathrm{H}, \mathrm{Me}, \mathrm{Cl}$

$\mathrm{R}^{2}=\mathrm{H}, \mathrm{Bn}$

\section{Scheme 99}

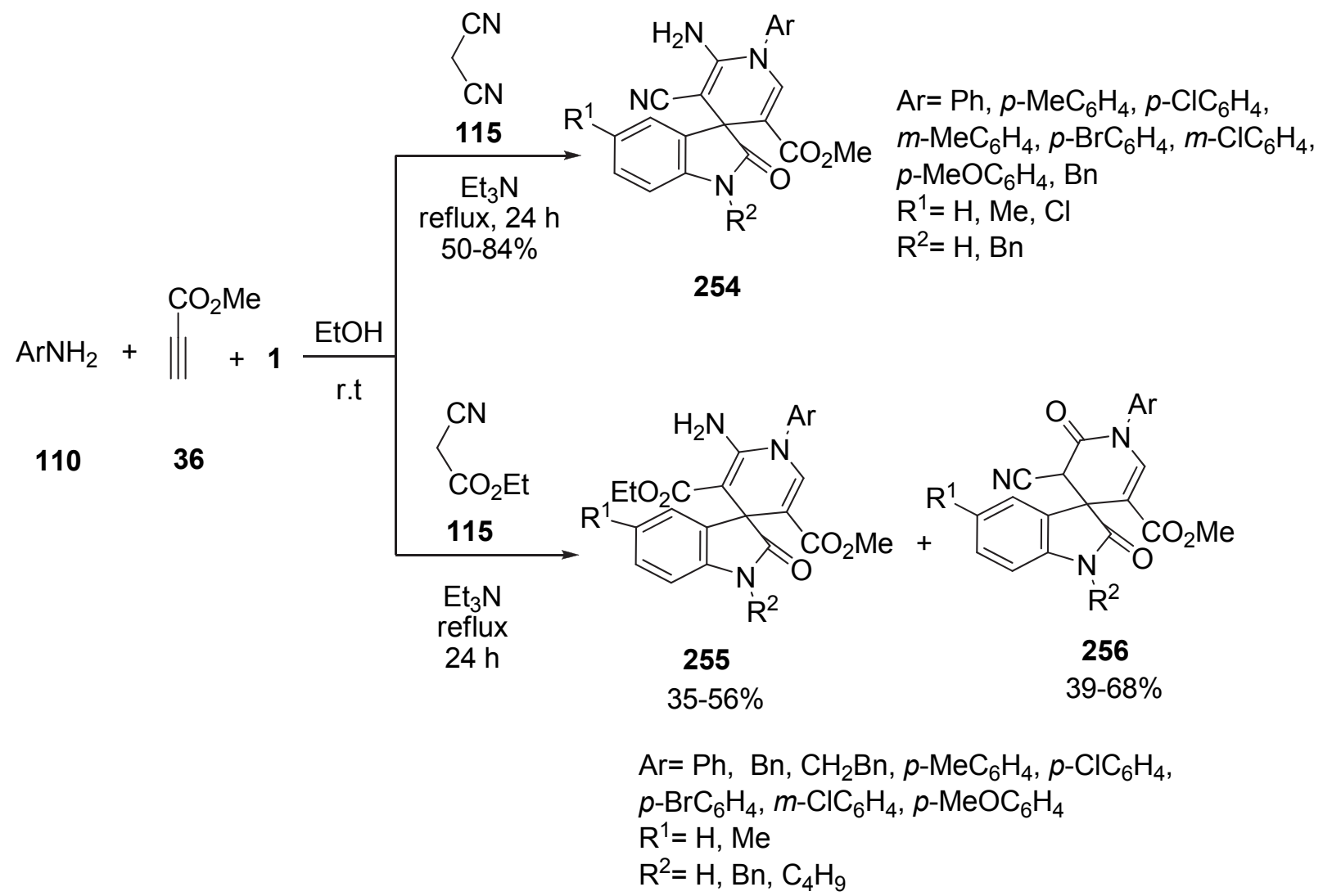

Scheme 100 
The same group accomplished domino reaction of arylamines $\mathbf{1 1 0}$, methyl propiolate $\mathbf{3 6}$, isatin 1 and malononitrile/ethyl 2-cyanoacetate 115 with triethylamine for the synthesis of functionalized spiro[indoline-3,4'-pyridine] 254-255 and spiro[indoline-3,4'-pyridinone] derivatives 256, respectively (Scheme 100). ${ }^{183}$

In a similar study, the $\mathrm{BF}_{3}$. $\mathrm{OEt}_{2}$-catalyzed reactions of acetylenedicarboxylates $\mathbf{3 2}$, arylamines 110, and isatins 1 afforded functionalized spiro[indoline-3,4'-pyridine]-2',3',5',6'tetracarboxylates 257 in moderate yields (Scheme 101). ${ }^{184-185}$

$$
\begin{aligned}
& 1+\mathrm{ArNH}_{2}+2|| \begin{array}{l}
\mathrm{CH}_{2} \mathrm{Cl}_{2}, \text { reflux } \\
24 \mathrm{~h}, 45-55 \%
\end{array} \\
& 110 \\
& \mathrm{R}^{1}=\mathrm{H}, \mathrm{Me} \\
& \mathrm{R}^{2}=\mathrm{H}, \mathrm{Bn} \\
& \mathrm{Ar}=\mathrm{Ph}, p-\mathrm{MeC}_{6} \mathrm{H}_{4}, p-\mathrm{MeOC}_{6} \mathrm{H}_{4}, p-\mathrm{EtC}_{6} \mathrm{H}_{4}
\end{aligned}
$$

\section{Scheme 101}

The same group found that the four-component reactions of arylamines 110, acetylenedicarboxylate derivatives $\mathbf{3 2}$, isatins $\mathbf{1}$, and dimedone $\mathbf{1 2 7}$ in acetic acid resulted in the novel functionalized tetrahydrospiro[indoline-3,2' -quinoline] derivatives 258 in moderate yields (Scheme 102). ${ }^{186}$ In a similar study, Debnath and Pramanik used the bimetallic $\mathrm{ZnFe}_{2} \mathrm{O}_{4}$ nanopowder as a dual Lewis acid-base combined catalyst in this reaction. ${ }^{187}$

In an exploratory experiment, the four-component reaction of $p$-methoxyaniline $\mathbf{1 1 0}$, dimethyl acetylenedicarboxylate 32, 1-benzyl-5-methylisatin 1 and cyclopentane-1,3-dione 259 in acetic acid was carried out by the same authors and there was no unit of acetylenedicarboxylate in the obtained product 260 (Scheme 103). ${ }^{188}$ This result indicated that the three-component reaction of arylamine 110, isatin $\mathbf{1}$, and cyclopentane-1,3-dione 259 gave the final spiro[dihydropyridine-oxindole] compounds 260, while the acetylenedicarboxylate could not take part in the reaction. 


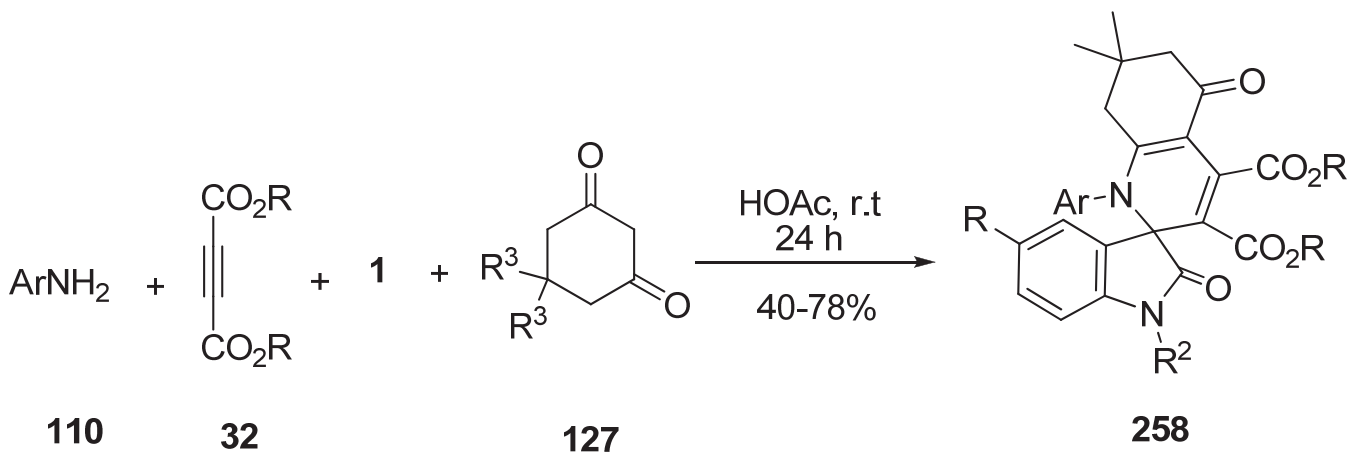

$$
\begin{aligned}
& \mathrm{Ar}=p-\mathrm{MeC}_{6} \mathrm{H}_{4}, \mathrm{Ph}, p-\mathrm{ClC}_{6} \mathrm{H}_{4}, p-\mathrm{MeOC}_{6} \mathrm{H}_{4}, m-\mathrm{NO}_{2} \mathrm{C}_{6} \mathrm{H}_{4} \\
& \mathrm{R}=\mathrm{Me}, \mathrm{Et} \\
& \mathrm{R}^{1}=\mathrm{H}, \mathrm{Me}, \mathrm{Cl} \\
& \mathrm{R}^{2}=\mathrm{H}, \mathrm{CH}_{2} \mathrm{Ph}, n-\mathrm{C}_{4} \mathrm{H}_{9} \\
& \mathrm{R}^{3}=\mathrm{H}, \mathrm{Me}
\end{aligned}
$$

Scheme 102

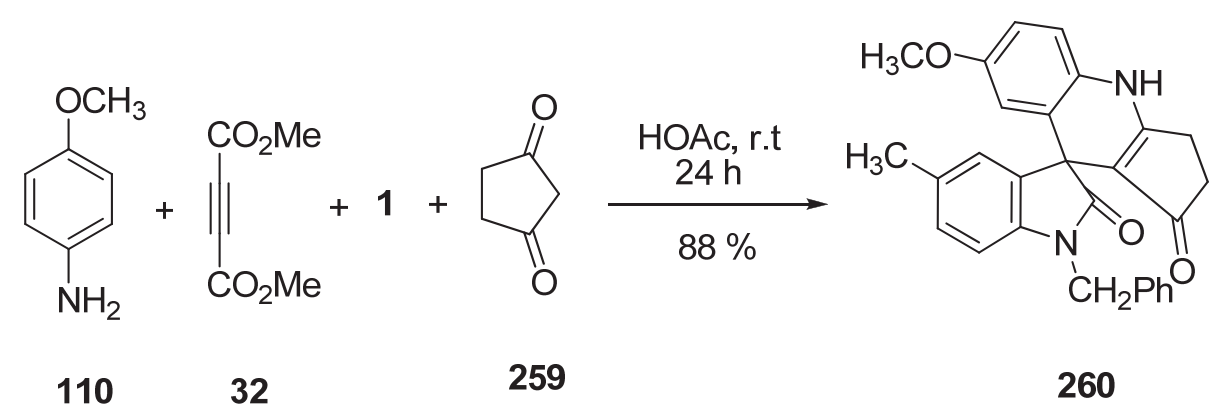

\section{Scheme 103}

A new type of catalytic stereoselective cascade pseudo four-component reaction was discovered by Elinson and co-workers. In this study, reaction of isatins $\mathbf{1}$ and cyclic ketones 261 with two molecules of malononitrile 115 catalyzed by triethylamine at ambient temperature stereoselectively resulted in the formation of tetracyclic spirooxindoles $\mathbf{2 6 2}$ in $60-90 \%$ yields (Scheme 104). ${ }^{189}$ 


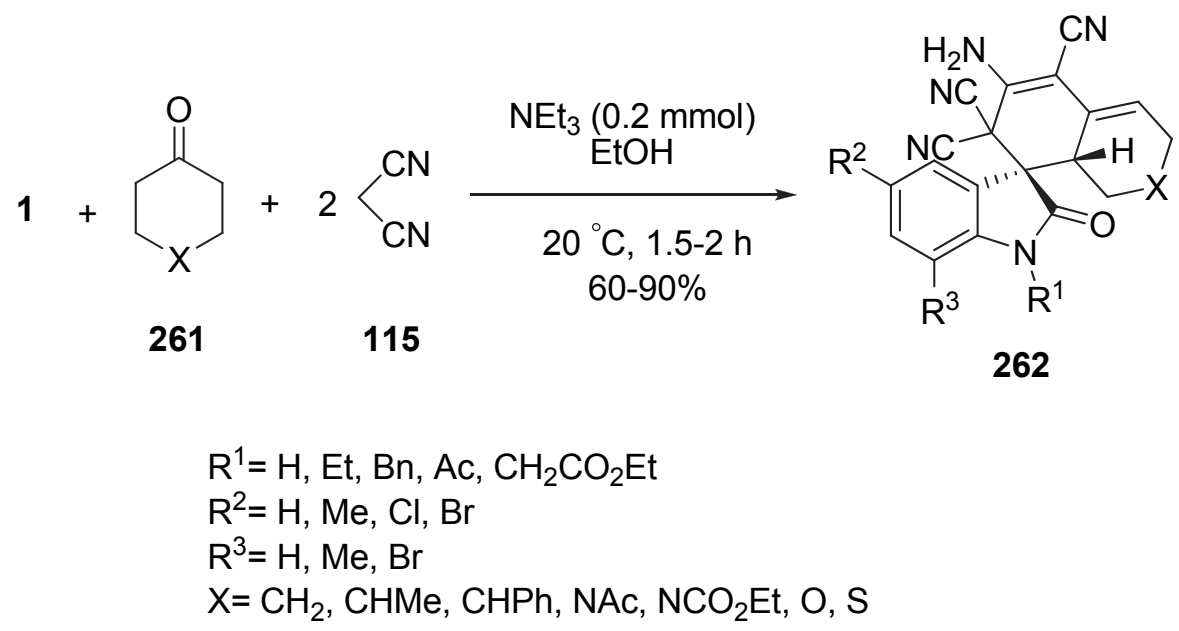

\section{Scheme 104}

An efficient regio- and chemoselective method for the synthesis of novel 3-amino-2'oxospiro[benzo[c]pyrano[3,2-a]phenazine-1,3'-indoline]-2-carbonitrile derivatives 264 has been developed via domino coupling of 2-hydroxynaphthalene-1,4-dione 193, benzene-1,2-diamines 263, isatins 1, and malononitrile 115 in the presence of DABCO (Scheme 105). ${ }^{190}$ The merit of this cascade formation of two $\mathrm{C}=\mathrm{N}$ bonds/Knoevenagel condensation/Michael addition/cyclization sequence is highlighted by its high atom-economy, efficiency of producing five new bonds (two $\mathrm{C}-\mathrm{N}$, two $\mathrm{C}-\mathrm{C}$, and one $\mathrm{C}-\mathrm{O}$ ), and one stereocenter in a single operation.

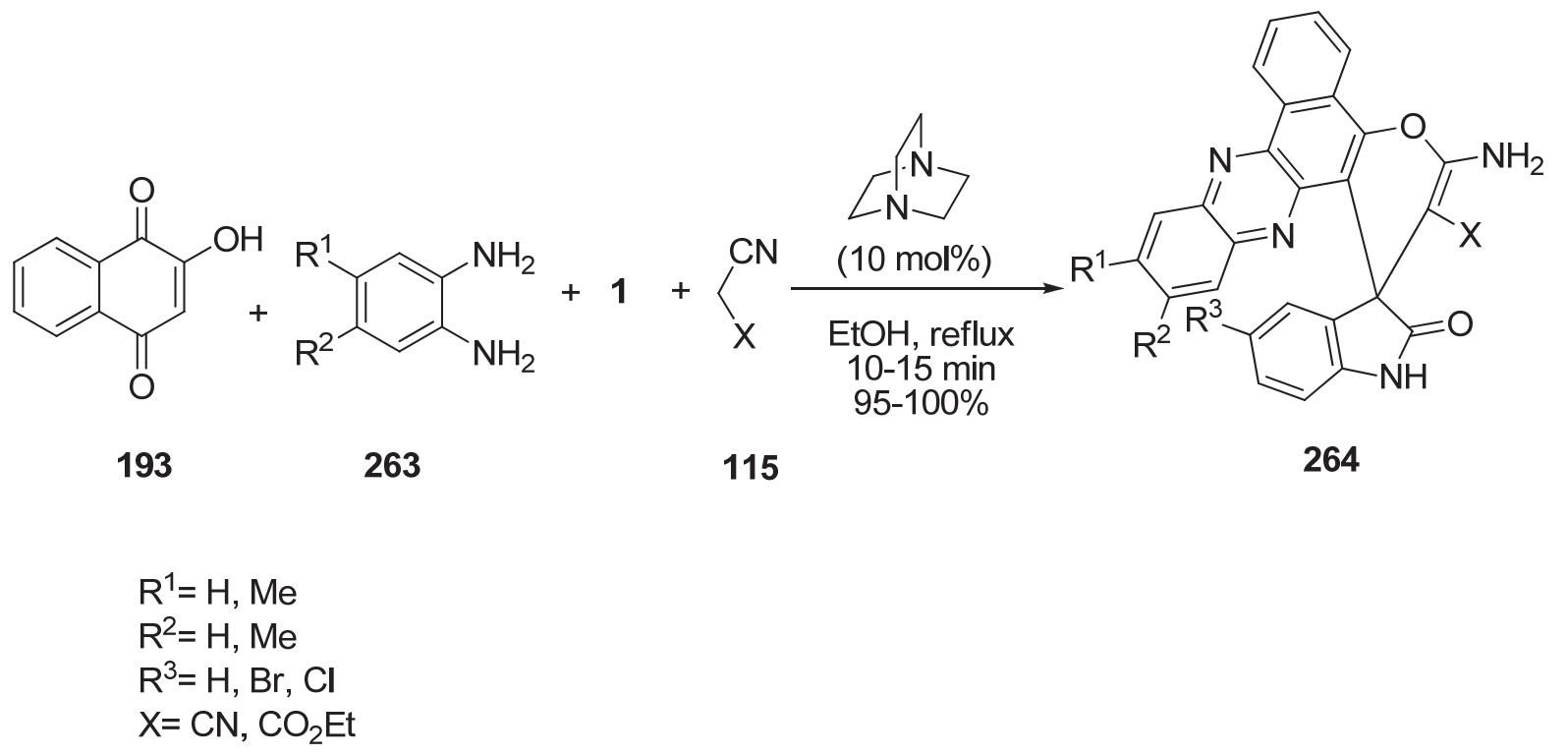

\section{Scheme 105}


An efficient one-pot synthesis of $5 H$-spiro[benzo[7,8]chromeno[2,3-c]pyrazole-7,3'indoline]-2',5,6-(9H)-trione derivatives 265 via a four-component reaction of hydrazine hydrate 130, $\beta$-keto esters 162, isatins 1 , and 2-hydroxynaphthalene-1,4-dione 193 catalyzed by $\mathrm{MgCl}_{2}$ in ethanol was reported by Song and co-workers (Scheme 106). ${ }^{191}$

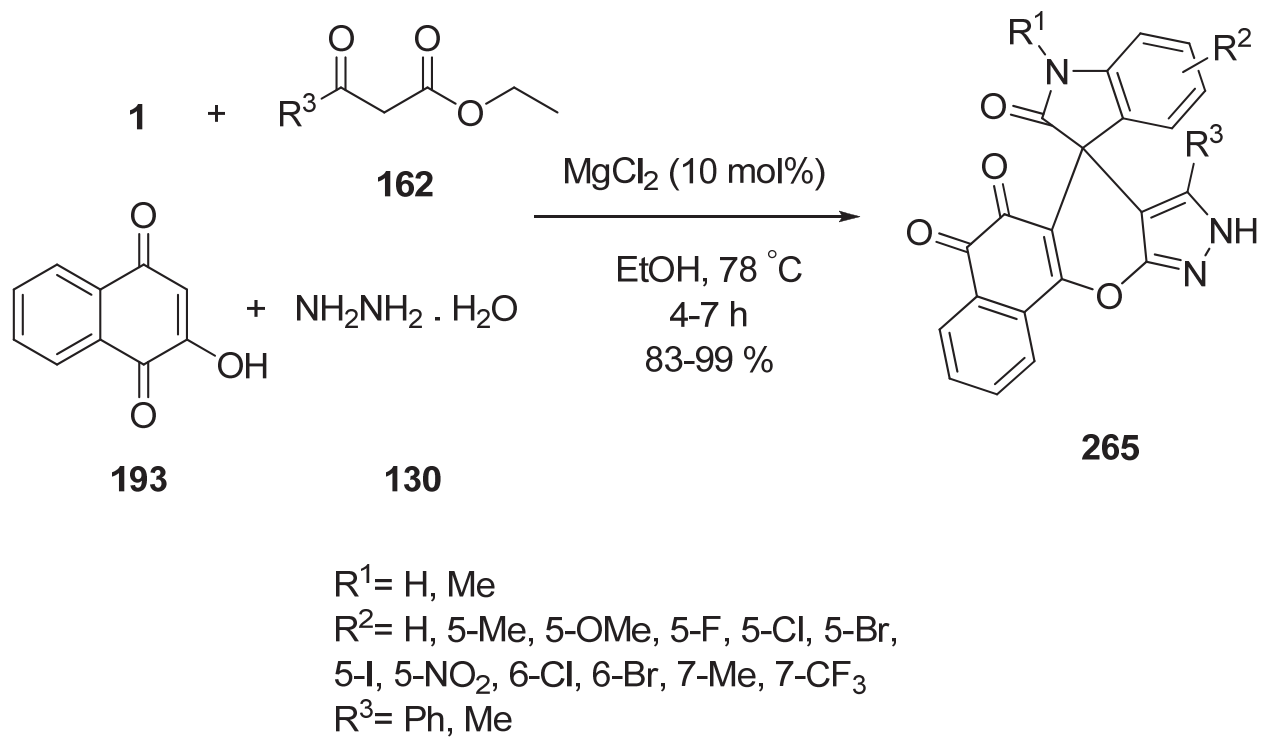

\section{Scheme 106}

A reaction for the synthesis of trifluoromethylated spirocyclic [indole-3,4-pyrano[2,3-c]pyrazole] derivatives 266 by reaction of isatins 1, malononitrile, ethyl cyanoacetate or cyanoacetamide 115, ethyl 4,4,4-trifluoroacetoacetate 162, and hydrazine $\mathbf{1 3 0}$ in the presence of a catalytic amount of piperidine was described (Scheme 107). ${ }^{192}$ Application of $L$-proline, ${ }^{193}$ piperidine under ultrasound irradiation, ${ }^{194}$ and propylamine functionalized nanoporous silica $\left(\mathrm{SBA}-\mathrm{Pr}-\mathrm{NH}_{2}\right)^{195}$ was also investigated in this reaction. In similar studies, one-pot reaction of isatins, malononitrile (or ethyl cyanoacetate), hydrazine hydrate (or phenylhydrazine), and 1,3dicarbonyl compounds was conducted under catalyst-free conditions, ${ }^{196}$ in the presence of 4dimethylaminopyridine (4-DMAP) catalyst, ${ }^{197}$ or using uncapped $\mathrm{SnO}_{2}$ quantum dots. ${ }^{198}$ Replacing malononitrile with naphthylamines in this reaction has been also investigated. ${ }^{199}$

The spiro pyranopyrazole derivatives $\mathbf{2 6 7}$ were synthesized by the reaction of isatins $\mathbf{1}$, malononitrile 115, hydrazine hydrate 130, and acetylenedicarboxylate derivatives 32 in catalystfree condition. At first pyrazolones were in situ formed from acetylenedicarboxylates and hydrazine hydrate and then reacted with another two components (Scheme 108). ${ }^{200} \mathrm{Et}_{3} \mathrm{~N}$ was also investigated as catalyst in this reaction. ${ }^{201-202}$ 


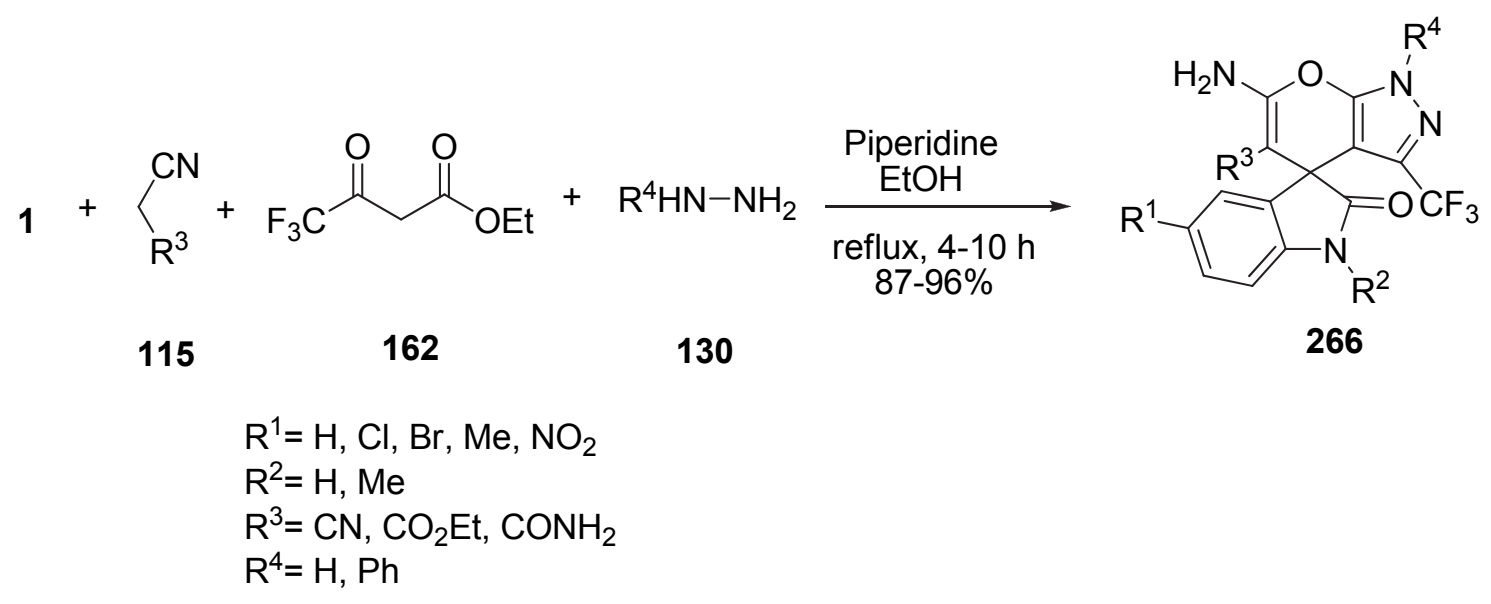

\section{Scheme 107}

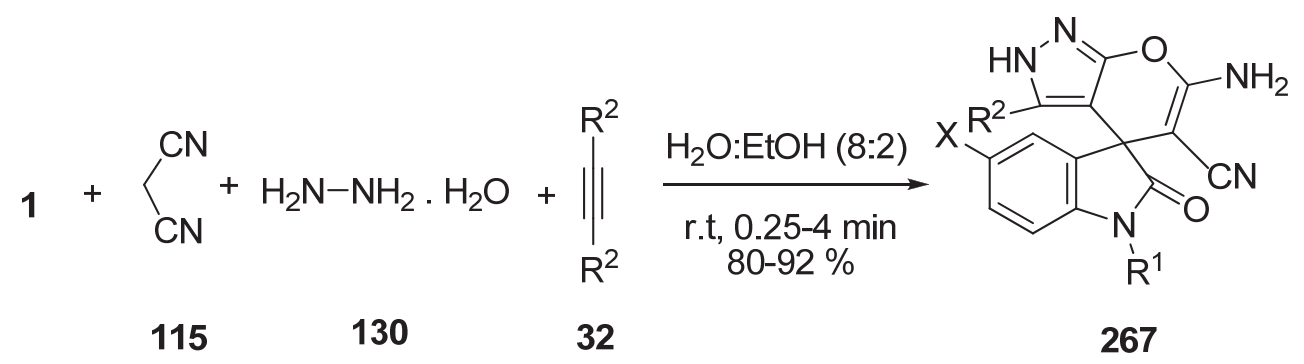

$$
\begin{aligned}
& X=\mathrm{H}, \mathrm{Cl}, \mathrm{I}, \mathrm{Me}, \mathrm{OMe} \\
& \mathrm{R}^{1}=\mathrm{H}, \mathrm{Me}, \mathrm{Et} \\
& \mathrm{R}^{2}=\mathrm{CO}_{2} \mathrm{Me}, \mathrm{CO}_{2} \mathrm{Et}
\end{aligned}
$$

\section{Scheme 108}

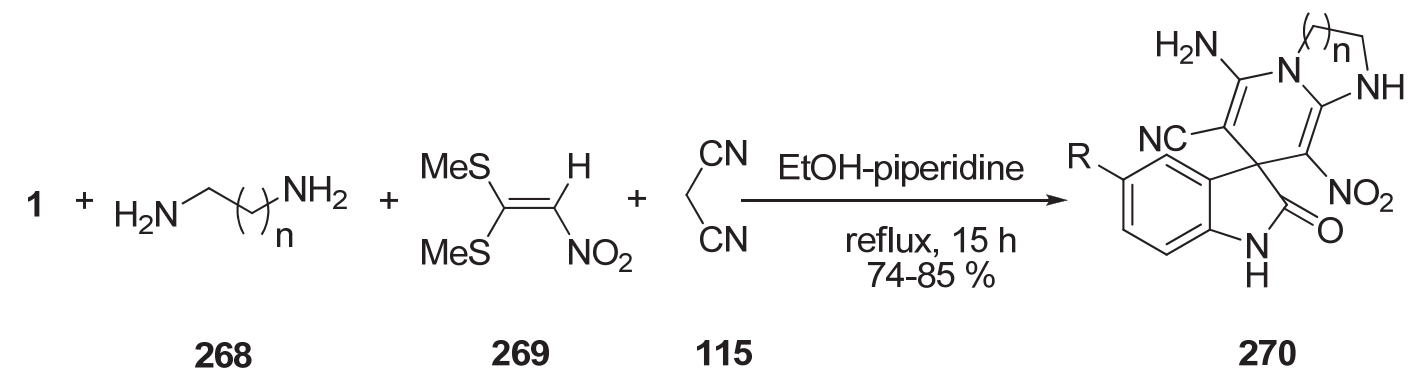

$\mathrm{R}=\mathrm{H}, \mathrm{Br}, \mathrm{NO}_{2}$

Diamine= 1,2-ethanediamine, 1,3-propanediamine,

1,4-butanediamine, 2,2-dimethyl-1,3-propanediamine

\section{Scheme 109}


Spirooxindole derivative containing 1,4-dihydropyridine-fused 1,3-diazaheterocycle fragments $\mathbf{2 7 0}$ were synthesized from the one-pot four-component reaction of 1,1bis(methylthio)-2-nitroethylene 269, 1,n-diamine $\mathbf{2 6 8}$, isatin or its derivatives $\mathbf{1}$, and malononitrile 115 (Scheme 109). ${ }^{203}$

A novel four-component reaction of isatins 1, 2-cyanoacetamide 160, cyclic 1,3-diketones 271 or 127 and alcohols was reported by Bazgir and co-workers (Scheme 110). ${ }^{204}$ The reaction gave the unexpected spirooxindole ethyl carboxylates 272 and 273 in excellent yields and the spirooxindole carboxamide was not observed.

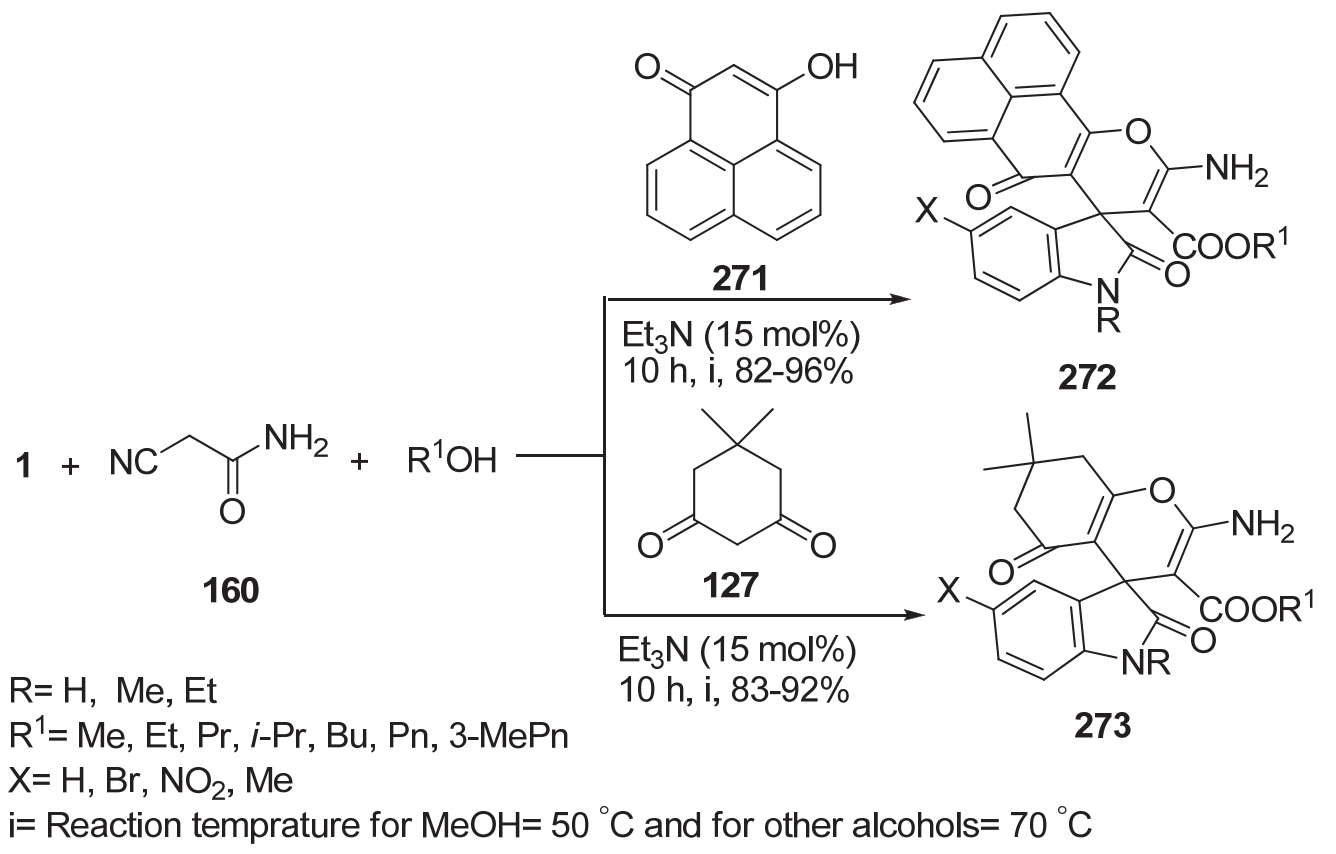

\section{Scheme 110}

\subsection{Synthesis involving five-component reactions of isatins}

A five-component reaction between 1,1-bis(methylthio)-2-nitroethylene 269, two equivalents of ammonia, isatin or its derivatives 1, and 1,3-dicarbonyl compounds 127 or 144 in the presence of $10 \mathrm{~mol} \% p$-toluenesulfonic acid ( $p$-TSA) generated spirooxindole heterocycles 274 (Scheme 111). ${ }^{205}$

A previously unknown class of highly substituted pyrazoline-spirooxindoles 277 was prepared by an uncatalyzed approach incorporating a domino nucleophilic substitution / condensation / aza-ene addition cyclization reaction sequence. 1,1-Dihydrazino-2-nitroethylene 275, which was generated in situ from the nucleophilic substitution reaction of hydrazine 130 and 1,1-bis(methylthio)-2-nitroethylene 269, was isolated and allowed to condense with isatins $\mathbf{1}$ followed by an intramolecular aza-ene addition cyclization (Scheme 112). ${ }^{206}$ A pseudo-fivecomponent reaction was also used in similar condition for the synthesis of the same products. This procedure avoided the isolation of the intermediate $275 .^{207}$ 


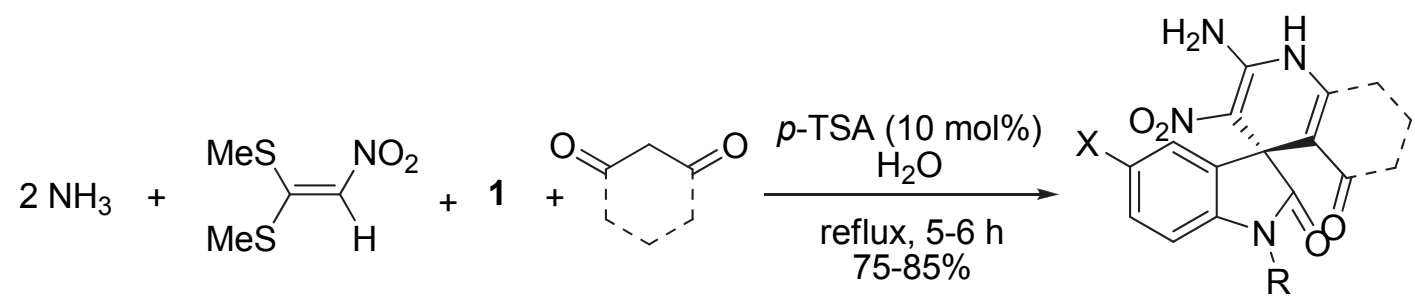

$\mathrm{X}=\mathrm{H}, \mathrm{Br}, \mathrm{NO}_{2}$

$\mathrm{R}=\mathrm{H}, \mathrm{Me}, \mathrm{Bn}$

1,3-dicarbonyls:

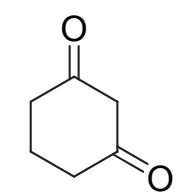<smiles>CN1C(=O)CC(=O)N(C)C1=O</smiles>

\section{Scheme 111}
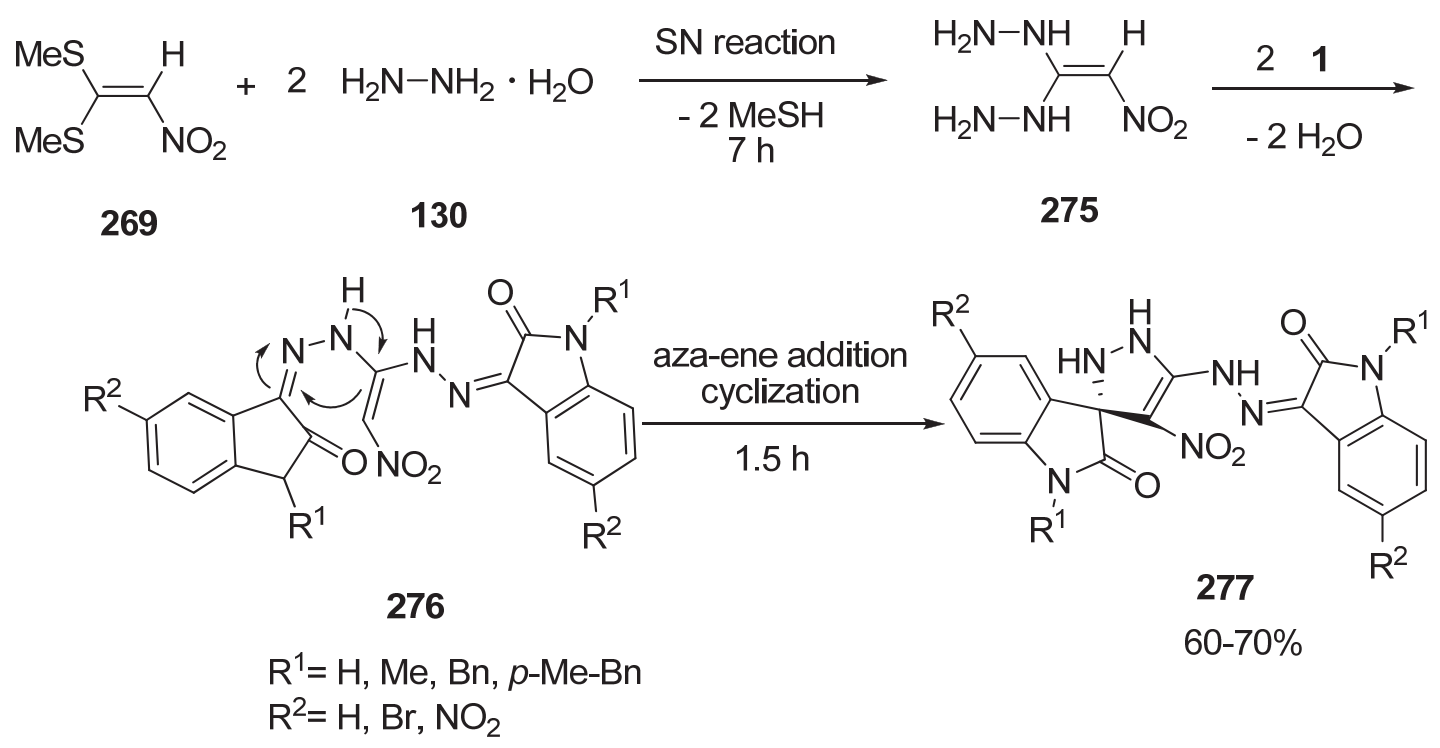

\section{Scheme 112}

\section{Conclusions}

Isatins, as a type of unsymmetrical cyclic ketone with high reactivity, have proven to be important privileged building blocks in the synthesis of spiro-heterocycles with potential bioactivities. The most commonly used isatin derivatives were employed in design of the spirocyclic scaffolds. This review surveyed the last 4-year progress on the construction of spirofused heterocyclic scaffolds derived from isatin with typical examples. 


\section{Acknowledgements}

We are grateful for financial support from the Research Council of Alzahra University.

\section{References}

1. Guo, Y.; Chen, F. Zhongcaoyao 1986, 17. Chem. Abstr. 104, $213068 \mathrm{f}$.

2. Erdmann, O. L. J. Prakt. Chem. 1840, 19, 321.

3. Laurent, A. Ann. Chim. Phys. 1840, 3, 393.

4. Kumar, M.; Ramasamy, K.; Mani, V.; Mishra, R. K.; Majeed, A. B. A.; Clercq, E. D.; Narasimhan, B. Arabian. J. Chem. 2014, 7, 396.

http://dx.doi.org/10.1016/j.arabjc.2012.12.005

5. Havrylyuk, D.; Zimenkovsky, B.; Vasylenko, O.; Gzella, A.; Lesyk, R. J. Med. Chem. 2012, 55, 8630 .

http://dx.doi.org/10.1021/jm300789g

6. Kumar, S. B.; Ravinder, M.; Kishore, G.; Rao, V. J.; Yogeeswari, P.; Sriram, D. Med. Chem. Res. 2014, 23, 1934.

http://dx.doi.org/10.1007/s00044-013-0787-X

7. Han, K.; Zhou, Y.; Liu, F.; Guo, Q.; Wang, P.; Yang, Y.; Song, B.; Liu, W.; Yao, Q.; Teng, Y.; Yu, P. Bioorg. Med. Chem. Lett. 2014, 24, 591.

http://dx.doi.org/10.1016/j.bmcl.2013.12.001

8. Liang, C.; Xia, J.; Lei, D.; Li, X.; Yao, Q.; Gao, J. Eur. J. Med. Chem. 2014, 74, 742. http://dx.doi.org/10.1016/j.ejmech.2013.04.040

9. Kumar, K.; S. Carrere-Kremer; Kremer, L.; Gueerardel, Y.; Biot, C.; Kumar, V. Organometallics 2013, 32, 5713.

http://dx.doi.org/10.1021/om301157z

10. Mondal, P.; Jana, S.; Balaji, A.; Ramakrishna, R.; Kanthal, L. J. Young Pharm. 2013, 4, 38. http://dx.doi.org/10.4103/0975-1483.93574

11. Raj, R.; Singh, P.; Singh, P.; Gut, J.; Rosenthal, P. J.; Kumar, V. Eur. J. Med. Chem. 2013, 62,590 .

http://dx.doi.org/10.1016/j.ejmech.2013.01.032

12. Paul, B. K.; Ray, D.; Guchhait, N. Phys. Chem. Chem. Phys. 2013, 15, 1275.

http://dx.doi.org/10.1039/C2CP42539D

13. Kiran, G.; Maneshwar, T.; Rajeshwar, Y.; Sarangapani, M. J. Chem. 2013, 2013, 1. http://dx.doi.org/10.1155/2013/192039

14. Yeung, B. K. S.; Zou, B.; Rottmann, M.; Lakshminarayana, S. B.; Ang, S. H.; Leong, S. Y.; Tan, J.; Wong, J.; Keller-Maerki, S.; Fischli, C.; Goh, A.; Schmitt, E. K.; Krastel, P.; Francotte, E.; Kuhen, K.; Plouffe, D.; Henson, K.; Wagner, T.; Winzeler, E. A.; Petersen, F.; Brun, R.; Dartois, V.; Diagana, T. T.; Keller, T. H. J. Med. Chem. 2010, 53, 5155. http://dx.doi.org/10.1021/jm100410f 
15. Ermut, G.; Karal, N.; Cetin, I.; Topcul, M.; Birteksoz, S. Marmara Pharm. J. 2013, 17, 147. http://dx.doi.org/10.12991/201317383

16. Song, Y.; Fu, X.; Qi, Y. EP Patent 2011/2573072 A1, 2011.

17. Jarrahpour, A. A.; Khalili, D. Molbank 2005, 4, M437. http://dx.doi.org/10.3390/M437

18. Basabe-Desmonts, L.; Reinhoudt, D. N.; Crego-Calama, M. Chem. Soc. Rev. 2007, 36, 993. http://dx.doi.org/10.1039/b609548h

19. Ding, K.; Lu, Y.; Nikolovska-Coleska, Z.; Wang, G.; Qiu, S.; Shangary, S.; Gao, W.; Qin, D.; Stuckey, J.; Krajewski, K.; Roller, P. P.; Wang, S. J. Med. Chem. 2006, 49, 3432. http://dx.doi.org/10.1021/jm051122a

20. Sumpter, W. C. Chem. Rev. 1944, 34, 393. http://dx.doi.org/10.1021/cr60109a003

21. Popp, F. D. Adv. Heterocycl. Chem. 1975, $18,1$. http://dx.doi.org/10.1016/S0065-2725(08)60127-0

22. da Silva, J. F. M.; Garden, S. J.; Pinto, A. C. J. J. Braz. Chem. Soc. 2001, 12, 273. http://dx.doi.org/10.1590/S0103-50532001000300002

23. Ball-Jones, N. R.; Badillo, J. J.; Franz, A. K. Org. Biomol. Chem. 2012, 10, 5165. http://dx.doi.org/10.1039/c2ob25184a

24. Floresa, M.; Pena, J.; Garcia-García, P.; Garrido, N. M.; Díez, D. Curr. Org. Chem. 2013, $17,1957$. http://dx.doi.org/10.2174/13852728113179990092

25. Liu, Y.; Wang, H.; Wan, J. Asian J. Org. Chem. 2013, 2, 374. http://dx.doi.org/10.1002/ajoc.201200180

26. Pakravan, P.; Kashanian, S.; Khodaei, M.; Harding, F. J. Pharm. Rep. 2013, 65, 313. http://dx.doi.org/10.1016/S1734-1140(13)71007-7

27. Singh, G. S.; Desta, Z. Y. Chem. Rev. 2012, 112, 6104. http://dx.doi.org/10.1021/cr300135y

28. Xia, M.; Ma, R.-Z. J. Heterocycl. Chem. 2014, 51, 539. http://dx.doi.org/10.1002/jhet.1114

29. Borad, M. A.; Bhoi, M. N.; Prajapati, N. P.; Patel, H. D. Synth. Commun. 2014, 44, 897. http://dx.doi.org/10.1080/00397911.2013.843196

30. Borad, M. A.; Bhoi, M. N.; Prajapati, N. P.; Patel, H. D. Synth. Commun. 2014, 44, 1043. http://dx.doi.org/10.1080/00397911.2013.858361

31. Khanna, P.; Panda, S. S.; Khanna, L.; Jain, S. C. Mini-Rev. Org. Chem. 2014, 11, 73. http://dx.doi.org/10.2174/1570193X1101140402101831

32. Lashgari, N.; Mohammadi Ziarani, G. Arkivoc 2012, i, 277. http://dx.doi.org/10.3998/ark.5550190.0013.108

33. Sunderhaus, J. D.; Martin, S. F. Chem. Eur. J. 2009, 15, 1300. http://dx.doi.org/10.1002/chem.200802140 
34. Guillena, G.; Ramon, D. J.; Yus, M. Tetrahedron: Asymmetry 2007, 18, 693. http://dx.doi.org/10.1016/j.tetasy.2007.03.002

35. Liu, H.; Dou, G.; Shi, D. J. Comb. Chem. 2010, 12, 633. http://dx.doi.org/10.1021/cc100035q

36. Litvinov, Y. M.; Shestopalov, A. A.; Rodinovskaya, L. A.; Shestopaqlov, A. M. J.Comb. Chem. 2009, 11, 914. http://dx.doi.org/10.1021/cc900076j

37. Rajanarendar, E.; Ramakrishna, S.; Reddy, K. G.; Nagaraju, D.; Reddy, Y. N. Bioorg. Med. Chem. Lett. 2013, 23, 3954. http://dx.doi.org/10.1016/j.bmcl.2013.04.053

38. Pavlovskaya, T. L.; Yaremenko, F. G.; Lipson, V. V.; Shishkina, S. V.; Shishkin, O. V.; Musatov, V. I.; Karpenko, A. S. Beilstein J. Org. Chem. 2014, 10, 117. http://dx.doi.org/10.3762/bjoc.10.8

39. Kaur, A.; Singh, B.; Vyas, B.; Silakari, O. Eur. J. Med. Chem. 2014, 79, 282. http://dx.doi.org/10.1016/j.ejmech.2014.04.022

40. Sarrafi, Y.; Hamzehloueian, M.; Alimohammadi, K.; Yeganegi, S. J. Mol. Struct. 2012, $1030,168$. http://dx.doi.org/10.1016/j.molstruc.2012.04.013

41. Huang, H.; Xu, Y.; Mao, F.; Zhu, J.; Jiang, H.; Li, J. Tetrahedron Lett. 2015, 56, 586. http://dx.doi.org/10.1016/j.tetlet.2014.12.011

42. Liu, J.; Sun, H.; Liu, X.; Ouyang, L.; Kang, T.; Xie, Y.; Wang, X. Tetrahedron Lett. 2012, $53,2336$.

http://dx.doi.org/10.1016/j.tetlet.2012.02.099

43. Sapnakumari, M.; Narayana, B.; Samshuddin, S.; Sarojini, B. K. Molbank 2013, M802, 1. http://dx.doi.org/10.3390/M802

44. Chen, G.; Yang, J.; Gao, S.; Zhang, Y.; X-J., H. Res. Chem. Intermed. 2013, 39, 1245. http://dx.doi.org/10.1007/s11164-012-0680-0

45. He, J.; Ouyang, G.; Yuan, Z.; Tong, R.; Shi, J.; Ouyang, L. Molecules 2013, 18, 5142. http://dx.doi.org/10.3390/molecules18055142

46. Arun, Y.; Saranraj, K.; Balachandran, C.; Perumal, P. T. Eur. J. Med. Chem. 2014, 74, 50. http://dx.doi.org/10.1016/j.ejmech.2013.12.027

47. Singh, S. N.; Regati, S.; Paul, A. K.; Layek, M.; Jayaprakash, S.; Reddy, K. V.; Deora, G. S.; Mukherjee, S.; Pal, M. Tetrahedron Lett. 2013, 54, 5448.

http://dx.doi.org/10.1016/j.tetlet.2013.07.126

48. Yang, F.; Sun, J.; Gao, H.; Yan, C. G. RSC Adv. 2015, 5, 32786. http://dx.doi.org/10.1039/c5ra04102c

49. Shi, F.; Zhu, R.-Y.; Liang, X.; Tua, S.-J. Adv. Synth. Catal. 2013, 355, 2447. http://dx.doi.org/10.1002/adsc.201300366

50. Tan, W.; Zhu, X.-T.; Zhang, S.; Xing, G.-J.; Zhu, R.-Y.; Shi, F. RSC Adv. 2013, 3, 10875. http://dx.doi.org/10.1039/c3ra40874d 
51. Shi, F.; Tao, Z.-L.; Luo, S.-W.; Tu, S.-J.; Gong, L.-Z. Chem. Eur. J. 2012, 18, 6885. http://dx.doi.org/10.1002/chem.201200358

52. Dai, W.; Jiang, X.-L.; Wu, Q.; Shi, F.; Tu, S.-J. J. Org. Chem. 2015, 80, 5737. http://dx.doi.org/10.1021/acs.joc.5b00708

53. Wang, C.-S.; Zhu, R.-Y.; Zheng, J.; Shi, F.; Tu, S.-J. J. Org. Chem. 2015, 80, 512. http://dx.doi.org/10.1021/jo502516e

54. Huang, Z.; Zhao, Q.; Chen, G.; Wang, H.; Lin, W.; Xu, L.; Liu, H.; Wang, J.; Shi, D.; Wang, Y. Molecules 2012, 17, 12704. http://dx.doi.org/10.3390/molecules171112704

55. Barman, P. D.; Goyal, D.; Daravath, U. K.; Sanyal, I.; Mandal, S. B.; Banerjee, A. K. Tetrahedron Lett. 2013, 54, 3801. http://dx.doi.org/10.1016/j.tetlet.2013.05.027

56. Dandia, A.; Jain, A. K.; Laxkar, A. K. RSC Adv. 2013, 3, 8422. http://dx.doi.org/10.1039/c3ra00170a

57. Kia, Y.; Osman, H.; Suresh Kumar, R.; Murugaiyah, V.; Perumal, A. B. S.; Wahab, H. A.; Bing, C. S. Bioorg. Med. Chem. 2013, 21, 1696. http://dx.doi.org/10.1016/j.bmc.2013.01.066

58. Kia, Y.; Osman, H.; Suresh Kumar, R.; Basiri, A.; Murugaiyah, V. Bioorg. Med. Chem. 2014, 22, 1318. http://dx.doi.org/10.1016/j.bmc.2014.01.002

59. Kia, Y.; Osman, H.; Suresh Kumar, R.; Basiri, A.; Murugaiyah, V. Bioorg. Med. Chem. Lett. 2014, 24, 1815. http://dx.doi.org/10.1016/j.bmcl.2014.02.019

60. Yan, J. J. Chem. Res. 2014, 38, 50. http://dx.doi.org/10.3184/174751914X13865875476588

61. Dandia, A.; Jain, A. K.; Laxkar, A. K.; Bhati, D. S. Tetrahedron Lett. 2013, 54, 3180. http://dx.doi.org/10.1016/j.tetlet.2013.04.033

62. Arun, Y.; Bhaskar, G.; Balachandran, C.; Ignacimuthu, S.; Perumal, P. T. Bioorg. Med. Chem. Lett. 2013, 23, 1839.

http://dx.doi.org/10.1016/j.bmcl.2013.01.023

63. Bhaskar, G.; Arun, Y.; Balachandran, C.; Saikumar, C.; Perumal, P. T. Eur. J. Med. Chem. 2012, 51, 79. http://dx.doi.org/10.1016/j.ejmech.2012.02.024

64. Dandia, A.; Jain, A. K.; Laxkar, A. K. Tetrahedron Lett. 2013, 54, 3929. http://dx.doi.org/10.1016/j.tetlet.2013.05.035

65. Jain, R.; Sharma, K.; Kumar, D. Tetrahedron Lett. 2012, 53, 1993. http://dx.doi.org/10.1016/j.tetlet.2012.02.029

66. Yang, J.-M.; Hu, Y.; Li, Q.; Yu, F.; Cao, J.; Fang, D.; Huang, Z.-B.; Shi, D.-Q. ACS Comb. Sci. 2014, 16, 139. http://dx.doi.org/10.1021/co400096c 
67. Saravanan, P.; Pushparaj, S.; Raghunathan, R. Tetrahedron Lett. 2013, 54, 3449.

http://dx.doi.org/10.1016/j.tetlet.2013.04.091

68. Bakthadoss, M.; Kannan, D.; Sivakumar, G. Synthesis 2012, 44, 793.

http://dx.doi.org/10.1055/s-0031-1289704

69. Chen, G.; Yang, J.; Gao, S.; He, H.; Li, S.; Di, Y.; Chang, Y.; Lu, Y.; Hao, X. Mol. Divers. 2012, 16, 151.

http://dx.doi.org/10.1007/s11030-011-9342-1

70. Chen, G.; Miao, Y.-Q.; Zhou, R.; Zhang, L.; Zhang, J.; Hao, X.-J. Res. Chem. Intermed. 2013, 39, 2445.

http://dx.doi.org/10.1007/s11164-012-0770-z

71. Sankaran, M.; Uvarani, C.; Chandraprakash, K.; Lekshmi, S. U.; Suparna, S.; Platts, J.;

Mohan, P. S. Mol. Divers. 2014, 18, 269.

http://dx.doi.org/10.1007/s11030-013-9498-y

72. Sarrafi, Y.; Sadatshahabi, M.; Hamzehloueian, M.; Alimohammadi, K.; Tajbakhsh, M.

Synthesis 2013, 45, 2294.

http://dx.doi.org/10.1055/s-0033-1338492

73. Alimohammadi, K.; Sarrafi, Y.; Rajabpour, B. C. R. Chimie 2014, 17, 156.

http://dx.doi.org/10.1016/j.crci.2013.06.003

74. Hazra, A.; Bharitkar, Y. P.; Chakraborty, D.; Mondal, S. K.; Singal, N.; Mondal, S.; Maity, A.; Paira, R.; Banerjee, S.; Mondal, N. B. ACS Comb. Sci. 2012, 15, 41.

http://dx.doi.org/10.1021/co3001154

75. Wu, G.; Ouyang, L.; Liu, J.; Zeng, S.; Huang, W.; Han, B.; Wu, F.; He, G.; Xiang, M. Mol. Divers. 2013, 17, 271.

http://dx.doi.org/10.1007/s11030-013-9432-3

76. Taghizadeh, M. J.; Arvinnezhad, H.; Samadi, S.; Jadidi, K.; Javidan, A.; Notash, B.

Tetrahedron Lett. 2012, 53, 5148.

http://dx.doi.org/10.1002/chin.201251110

77. Kathirvelan, D.; Haribabu, J.; Reddy, B. S. R.; Balachandran, C.; Duraipandiyan, V.

Bioorg. Med. Chem. Lett. 2015, 25, 389.

http://dx.doi.org/10.1016/j.bmcl.2014.10.099

78. Javidan, A.; Taghizadeh, M. J.; Jadidi, K.; Notash, B. Monatsh. Chem. 2014, 145, 341.

http://dx.doi.org/10.1007/s00706-013-1089-1

79. Dandia, A.; Jain, A. K.; Laxkar, A. K.; Bhati, D. S. Tetrahedron 2013, 69, 2062.

http://dx.doi.org/10.1016/j.tet.2012.12.021

80. Naga Siva Rao, J.; Raghunathan, R. Tetrahedron Lett. 2012, 53, 854.

http://dx.doi.org/10.1016/j.tetlet.2011.12.025

81. Kumar, A.; Gupta, G.; Srivastava, S.; Kumar Bishnoi, A.; Saxena, R.; Kant, R.; Khanna, R. S.; Maulik, P. R.; Dwivedi, A. RSC Adv. 2013, 3, 4731.

http://dx.doi.org/10.1039/c3ra21595d

82. Ameta, K. L.; Kumar, B.; Rathore, N. S. Lett. Org. Chem. 2013, 10, 245. 


\section{http://dx.doi.org/10.2174/1570178611310040004}

83. Han, Y.; Wu, Q.; Sun, J.; Yan, C.-G. Tetrahedron 2012, 68, 8539.

http://dx.doi.org/10.1016/j.tet.2012.08.030

84. Sarkar, R.; Mukhopadhyay, C. Tetrahedron Lett. 2013, 54, 3706.

http://dx.doi.org/10.1016/j.tetlet.2013.05.017

85. Kiruthika, S. E.; Amritha, R.; Perumal, P. T. Tetrahedron Lett. 2012, 53, 3268.

http://dx.doi.org/10.1016/j.tetlet.2012.04.047

86. Sun, Y.; Sun, J.; Yan, C. Tetrahedron Lett. 2012, 53, 3647.

http://dx.doi.org/10.1016/j.tetlet.2012.05.023

87. Karamthulla, S.; Pal, S.; Nasim Khan, M.; Choudhury, L. H. RSC Adv. 2013, 3, 15576. http://dx.doi.org/10.1039/c3ra43289k

88. Chen, H.; Shi, D.-Q. J. Heterocycl. Chem. 2013, 50, 56. http://dx.doi.org/10.1002/jhet.993

89. Wang, J.; Bai, X.; Xu, C.; Wang, Y.; Lin, W.; Zou, Y.; Shi, D. Molecules 2012, 17, 8674. http://dx.doi.org/10.3390/molecules17078674

90. Rajasekaran, T.; Karthik, G.; Sridhar, B.; Subba Reddy, B. V. Org. Lett. 2013, 15, 1512. http://dx.doi.org/10.1021/o1400287q

91. Salahi, F.; Taghizadeh, M. J.; Arvinnezhad, H.; Moemeni, M.; Jadidi, K.; Notash, B. Tetrahedron Lett. 2014, 55, 1515. http://dx.doi.org/10.1016/j.tetlet.2013.11.097

92. Chandam, D. R.; Mulik, A. G.; Patil, P. P.; Jagdale, S. D.; Patil, D. R.; Deshmukh, M. B. Res. Chem. Intermed. 2015, 41, 761.

http://dx.doi.org/10.1007/s11164-013-1226-9

93. Singh, S.; Saquib, M.; Singh, S. B.; Singh, M.; Singh, J. RSC Adv. 2015, 5, 45152. http://dx.doi.org/10.1039/c5ra02794b

94. Hamama, W. S.; Gouda, M. A.; Badr, M. H.; Zoorob, H. H. J. Heterocycl. Chem. 2013, 50, 787.

http://dx.doi.org/10.1002/jhet.1569

95. Jain, R.; Sharma, K.; Kumar, D. Helv. Chim. Acta 2013, 96, 414. http://dx.doi.org/10.1002/hlca.201200168

96. Moghaddam, F. M.; Khodabakhshi, M. R.; Ghahremannejad, Z.; Koushki Foroushani, B.; Weng Ng, S. Tetrahedron Lett. 2013, 54, 2520. http://dx.doi.org/10.1016/j.tetlet.2013.03.023

97. Shi, F.; Xing, G.-J.; Zhu, R.-Y.; Tan, W.; Tu, S. Org. Lett. 2012, 15, 128. http://dx.doi.org/10.1021/ol303154k

98. Shi, F.; Zhu, R. Y.; Dai, W.; Wang, C. S.; Tu, S. J. Chem. Eur. J. 2014, 20, 2597. http://dx.doi.org/10.1002/chem.201304187

99. Dai, W.; Lu, H.; Li, X.; Shi, F.; Tu, S.-J. Chem. Eur. J. 2014, $20,11382$. http://dx.doi.org/10.1002/chem.201402485 
100. Shirvan, S. A.; Ghahremanzadeh, R.; Moghaddam, M. M.; Bazgir, A.; Zarnani, A. H.;

Akhondi, M. M. J. Heterocycl. Chem. 2012, 49, 951.

http://dx.doi.org/10.1002/jhet.898

101. Kamal, A.; Babu, K. S.; Vardhan, M. V. P. S. V.; Hussaini, S. M. A.; Mahesh, R.; Shaik, S. P.; Alarifi, A. Bioorg. Med. Chem. Lett. 2015, 25, 2199.

http://dx.doi.org/10.1016/j.bmcl.2015.03.054

102. De, K.; Bhaumik, A.; Banerjee, B.; Mukhopadhyay, C. Tetrahedron Lett. 2015, 56, 1614. http://dx.doi.org/10.1016/j.tetlet.2015.01.163

103. Rahmati, A.; Khalesi, Z. Tetrahedron 2012, 68, 8472.

http://dx.doi.org/10.1016/j.tet.2012.07.073

104. Yuvaraj, P.; Manivannan, K.; Reddy, B. S. R. Tetrahedron Lett. 2015, 56, 78.

http://dx.doi.org/10.1016/j.tetlet.2014.11.001

105. Mohammadi Ziarani, G.; Faramarzi, S.; Lashgari, N.; Badiei, A. R. J. Iran. Chem. Soc. 2014, 11, 701 . http://dx.doi.org/10.1007/s13738-013-0342-1

106. Dandia, A.; Laxkar, A. k.; Singh, R. Tetrahedron Lett. 2012, 53, 3012. http://dx.doi.org/10.1016/j.tetlet.2012.03.136

107. Rahmati, A.; Kenarkoohi, T.; Khavasi, H. R. ACS Comb. Sci. 2012, 14, 657. http://dx.doi.org/10.1021/co300047j

108. Esmaeili, A. A.; Amini-Ghalandarabad, S.; Mesbah, F.; Tasmimi, M.; Izadyar, M.; Fakhari, A. R.; Salimi, A. R. Tetrahedron 2015, 71, 2458. http://dx.doi.org/10.1016/j.tet.2015.01.055

109. Yang, H. B.; Guan, X.-Y.; Wei, Y.; Shi, M. Eur. J. Org. Chem. 2012, 2012, 2792. http://dx.doi.org/10.1002/ejoc.201200185

110. Liang, Y. R.; Chen, X. Y.; Wu, Q.; Lin, X. F. Tetrahedron 2015, 71, 616. http://dx.doi.org/10.1016/j.tet.2014.12.027

111. Yu, F.; Huang, R.; Ni, H.; Fan, J.; Yan, S.; Lin, J. Green Chem. 2013, 15, 453. http://dx.doi.org/10.1039/c2gc36552a

112. Alizadeh, A.; Moafi, L. Helv. Chim. Acta 2015, 98, 546. http://dx.doi.org/10.1002/hlca.201400263

113. Safaei, S.; Mohammadpoor-Baltork, I.; Khosropour, A. R.; Moghadam, M.; Tangestaninejad, S.; Mirkhani, V.; Khavasi, H. R. ACS Comb. Sci. 2013, 15, 141. http://dx.doi.org/10.1021/co3001204

114. Iarosnko, V. O.; Dudkin, S.; Sosnovskikh, V. Y.; Villinger, A.; Langer, P. Synthesis 2013, $45,971$. http://dx.doi.org/10.1055/s-0032-1318273

115. Vilches-Herrera, M.; Spannenberg, A.; Langer, P.; Iaroshenko, V. O. Tetrahedron 2013, 69, 5955.

http://dx.doi.org/10.1016/j.tet.2013.04.115

116. Naeimi, H.; Rashid, Z.; Zarnani, A. H.; Ghahremanzadeh, R. New J. Chem. 2014, 38, 348. 


\section{http://dx.doi.org/10.1039/C3NJ00940H}

117. Rad-Moghadam, K.; Youseftabar-Miri, L. J. Fluorine Chem. 2012, 135, 213. http://dx.doi.org/10.1016/j.jfluchem.2011.11.007

118. Rahmati, A.; Eskandari-Vashareh, M. J. Chem. Sci. 2014, 126, 169. http://dx.doi.org/10.1007/s12039-013-0552-1

119. Heravi, M. M.; Zakeri, M.; Moharami, A. J. Chem. Sci. 2012, 124, 865. http://dx.doi.org/10.1007/s12039-012-0284-7

120. Mondal, A.; Mukhopadhyay, C. J. Am. Chem. Soc. 2015, 17, 404. http://dx.doi.org/10.1021/acscombsci.5b00038

121. Karmakar, R.; Kayal, U.; Bhattacharya, B.; Maiti, G. Tetrahedron Lett. 2014, 55, 1370. http://dx.doi.org/10.1016/j.tetlet.2014.01.028

122. Dabiri, M.; Noroozi Tisseh, Z.; Bazgir, A. Monatsh. Chem. 2012, 143, 139. http://dx.doi.org/10.1007/s00706-011-0571-X

123. Zhao, H. W.; Li, B.; Tian, T.; Meng, W.; Yang, Z.; Song, X. Q.; Chen, X. Q.; Pang, H. L. Eur. J. Org. Chem. 2015, 3320. http://dx.doi.org/10.1002/ejoc.201500152

124. Ghahremanzadeh, R.; Rashid, Z.; Zarnani, A. H.; Naeimi, H. Appl. Catal., A 2013, 467, 270 . http://dx.doi.org/10.1016/j.apcata.2013.07.029

125. Ghahremanzadeh, R.; Rashid, Z.; Zarnani, A. H.; Naeimi, H. Ultrason. Sonochem. 2014, 21,1451 . http://dx.doi.org/10.1016/j.ultsonch.2014.02.014

126. Periyaraja, S.; Shanmugam, P.; Mandal, A. B.; Senthil Kumar, T.; Ramamurthy, P. Tetrahedron 2013, 69, 2891. http://dx.doi.org/10.1016/j.tet.2013.02.037

127. Gao, H.; Sun, J.; Yan, C. G. Synthesis 2014, 46, 489. http://dx.doi.org/10.1055/s-0033-1340459

128. Meshram, G.; Wagh, P.; Deshpande, S.; Amratlal, V. Lett. Org. Chem. 2013, 10, 445. http://dx.doi.org/10.2174/1570178611310060006

129. Baghernejad, B.; Khorshidi, M. Bull. Chem. Soc. Ethiop. 2013, 27, 309. http://dx.doi.org/10.4314/bcse.v27i2.17

130. Xie, X.; Peng, C.; He, G.; Leng, H.-J.; Wang, B.; Huang, W.; Han, B. Chem. Commun. 2012, 48, 10487. http://dx.doi.org/10.1039/c2cc36011j

131. Yang, H.-B.; Zhao, Y.-Z.; Sang, R.; Tang, X.-Y.; Shi, M. Tetrahedron 2013, 69, 9205. http://dx.doi.org/10.1016/j.tet.2013.08.071

132. Yang, H.; Takrouri, K.; Chorev, M. Curr. Org. Chem. 2012, 16, 1581. http://dx.doi.org/10.2174/138527212800840937

133. Mohammadi Ziarani, G.; Lashgari, N.; Badiei, A. Sci. Iran. C 2013, 20, 580. http://dx.doi.org/10.1016/j.scient.2012.11.018 
134. Rahmati, A.; Rezayan, A.; Alizadeh, M.; Nikbakht, A. J. Iran. Chem. Soc. 2013, 10, 521. http://dx.doi.org/10.1007/s13738-012-0187-z

135. Deng, J.; Mo, L. P.; Zhao, F. Y.; Zhang, Z. H.; Liu, S. X. ACS Comb. Sci. 2012, 14, 335. http://dx.doi.org/10.1021/co3000264

136. Mirhosseini Moghaddam, M.; Bazgir, A.; Akhondi, M. M.; Ghahremanzadeh, R. Chin. J. Chem. 2012, 30, 709. http://dx.doi.org/10.1002/cjoc.201280014

137. Guo, R. Y.; Wang, P.; Wang, G. D.; Mo, L. P.; Zhang, Z. H. Tetrahedron 2013, 69, 2056. http://dx.doi.org/10.1016/j.tet.2012.12.081

138. Mohammadi Ziarani, G.; Lashgari, N.; Faramarzi, S.; Badiei, A. Acta Chim. Slov. 2014, 61, 574.

139. Asadi, S.; Mohammadi Ziarani, G.; Rahimifard, M.; Abolhassani Soorki, A. Res. Chem. Intermed. 2015, 41, 6219. http://dx.doi.org/10.1007/s11164-014-1734-2

140. Paul, S.; Das, A. R. Tetrahedron Lett. 2013, 54, 1149. http://dx.doi.org/10.1016/j.tetlet.2012.12.079

141. Poomathi, N.; Mayakrishnan, S.; Muralidharan, D.; Srinivasan, R.; Perumal, P. T. Green Chem. 2015, 17, 3362.

http://dx.doi.org/10.1039/c5gc00006h

142. Kidwai, M.; Jahan, A.; Kumar Mishra, N. Appl. Catal., A 2012, 425- 426, 35. http://dx.doi.org/10.1016/j.apcata.2012.02.043

143. Hasaninejad, A.; Golzar, N.; Beyrati, M.; Zare, A.; Doroodmand, M. J. Mol. Catal. A: Chem. 2013, 372, 137. http://dx.doi.org/10.1016/j.molcata.2013.02.022

144. Saluja, P.; Aggarwal, K.; Khurana, J. M. Synth. Commun. 2013, 43, 3239. http://dx.doi.org/10.1080/00397911.2012.760130

145. Wu, C.; Shen, R.; Chen, J.; Hu, C. Bull. Korean Chem. Soc. 2013, 34, 2431. http://dx.doi.org/10.5012/bkcs.2013.34.8.2431

146. Mobinkhaledi, A.; Jabbarpour, M. J. Chem. Soc. Pak. 2013, 35, 1211.

147. Jalili-Baleh, L.; Mohammadi, N.; Khoobi, M.; Ma'mani, L.; Foroumadi, A.; Shafiee, A. Helv. Chim. Acta 2013, 96, 1601. http://dx.doi.org/10.1002/hlca.201200516

148. Mohammadi Ziarani, G.; Lashgari, N.; Badiei, A.; Shakiba, M. Chemija 2013, $24,142$.

149. Lashgari, N.; Mohammadi Ziarani, G.; Badiei, A.; Zarezadeh-Mehrizi, M. J. Heterocycl. Chem. 2014, 51, 1628. http://dx.doi.org/10.1002/jhet.1746

150. Mohammadi Ziarani, G.; Badiei, A.; Mousavi, S.; Lashgari, N.; Shahbazi, A. Chin. J. Catal. 2012, 33, 1832. http://dx.doi.org/10.1016/S1872-2067(11)60456-7 
151. Mohammadi Ziarani, G.; Hosseini Mohtasham, N.; Lashgari, N.; Badiei, A.; Amanlou, M.; Bazl, R. J. NanoStruct. 2013, 2, 489.

152. Baharfar, R.; Azimi, R. Synth. Commun. 2014, 44, 89. http://dx.doi.org/10.1080/00397911.2013.789527

153. Safaei, H. R.; Shekouhy, M.; Shirinfeshan, A.; Rahmanpur, S. Mol. Divers. 2012, 16, 669. http://dx.doi.org/10.1007/s11030-012-9392-z

154. Khurana, J. M.; Yadav, S. Aust. J. Chem. 2012, 65, 314. http://dx.doi.org/10.1071/CH11444

155. Riyaz, S.; Naidu, A.; Dubey, P. K. Lett. Org. Chem. 2012, 9, 101. http://dx.doi.org/10.2174/157017812800221771

156. Sarrafi, Y.; Mehrasbi, E.; Vahid, A.; Tajbakhsh, M. Chin. J. Catal. 2012, 33, 1486. http://dx.doi.org/10.1016/S1872-2067(11)60423-3

157. Karmakar, B.; Nayak, A.; Banerji, J. Tetrahedron Lett. 2012, 53, 5004. http://dx.doi.org/10.1016/j.tetlet.2012.07.030

158. Rao, B. M.; Reddy, G. N.; Reddy, T. V.; Prabhavathi Devi, B. L. A.; Prasad, R. B. N.; Yadav, J. S.; Subba Reddy, B. V. Tetrahedron Lett. 2013, 54, 2466. http://dx.doi.org/10.1016/j.tetlet.2013.02.089

159. He, T.; Zeng, Q. Q.; Yang, D. C.; He, Y. H.; Guan, Z. RSC Adv. 2015, 5, 37843. http://dx.doi.org/10.1039/c4ra16825a

160. Wang, G.-D.; Zhang, X.-N.; Zhang, Z.-H. J. Heterocycl. Chem. 2013, 50, 61. http://dx.doi.org/10.1002/jhet.994

161. Kidwai, M.; Jain, A.; Nemaysh, V.; Kumar, R.; Luthra, P. Med. Chem. Res. 2013, 22, 2717. http://dx.doi.org/10.1007/s00044-012-0249-x

162. Wu, Q.; Feng, H.; Guo, D.-D.; Yi, M.-S.; Wang, X.-H.; Jiang, B.; Tu, S.-J. J. Heterocycl. Chem. 2013, 50, 599. http://dx.doi.org/10.1002/jhet.1537

163. Safaei, H. R.; Shekouhy, M.; Rahmanpur, S.; Shirinfeshan, A. Green Chem. 2012, 14, 1696. http://dx.doi.org/10.1039/c2gc35135h

164. Azizi, N.; Dezfooli, S.; Mahmoudi Hashemi, M. J. Mol. Liq. 2014, 194, 62. http://dx.doi.org/10.1016/j.molliq.2014.01.009

165. Ponpandian, T.; Muthusubramanian, S. Synth. Commun. 2014, 44, 868. http://dx.doi.org/10.1080/00397911.2013.837488

166. Elinson, M. N.; Ilovaisky, A. I.; Merkulova, V. M.; Zaimovskaya, T. A.; Nikishin, G. I. Mendeleev Commun. 2012, 22, 143. http://dx.doi.org/10.1016/j.mencom.2012.05.010

167. Zakeri, M.; Nasef, M. M.; Abouzari-Lotf, E.; Moharami, A.; Heravi, M. M. J. Ind. Eng. Chem. 2015, 29, 273. http://dx.doi.org/10.1016/j.jiec.2015.03.035

168. Park, J. H.; Lee, Y. R.; Kim, S. H. Tetrahedron 2013, 69, 9682. 


\section{http://dx.doi.org/10.1016/j.tet.2013.09.021}

169. Pal, S.; Nasim Khan, M.; Karamthulla, S.; Choudhury, L. H. Tetrahedron Lett. 2015, 56, 359.

http://dx.doi.org/10.1016/j.tetlet.2014.11.095

170. Parthasarathy, K.; Praveen, C.; Balachandran, C.; Kumar, P. S.; Ignacimuthu, S.; Perumal, P. T. Bioorg. Med. Chem. Lett. 2013, 23, 2708. http://dx.doi.org/10.1016/j.bmc1.2013.02.086

171. Rahmati, A.; Khalesi, Z.; Kenarkoohi, T. Comb. Chem. High Throughput Screen. 2014, 17, 132.

http://dx.doi.org/10.2174/13862073113166660067

172. Kamalraja, J.; Murugasan, P.; Perumal, P. T. RSC Adv. 2014, 4, 19422. http://dx.doi.org/10.1039/c4ra01524j

173. Jin, S.-S.; Wang, H.; Guo, H.-Y. Tetrahedron Lett. 2013, 54, 2353. http://dx.doi.org/10.1016/j.tetlet.2013.02.073

174. Noroozi Tisseh, Z.; Ahmadi, F.; Dabiri, M.; Khavasi, H. R.; Bazgir, A. Tetrahedron Lett. 2012, 53, 3603. http://dx.doi.org/10.1016/j.tetlet.2012.05.019

175. Majumdar, K. C.; Ponra, S.; Nandi, R. K. Tetrahedron Lett. 2012, 53, 1732. http://dx.doi.org/10.1016/j.tetlet.2012.01.099

176. Liu, R.; Wu, M.; Li, G. Heteroat. Chem. 2014, 25, 140. http://dx.doi.org/10.1002/hc.21146

177. Sindhu, J.; Singh, H.; Khurana, J. M. Mol. Divers. 2014, 18, 345. http://dx.doi.org/10.1007/s11030-014-9505-y

178. Li, X.; Liu, H.; Zheng, A.; Li, Z.; Yu, X.; Yi, P. Synth. Commun. 2014, 44, 1414. http://dx.doi.org/10.1080/00397911.2011.557850

179. Ghahremanzadeh, R.; Moghaddam, M. M.; Bazgir, A.; Akhondi, M. M. Chin. J. Chem. 2012, 30, 321. http://dx.doi.org/10.1002/cjoc.201180471

180. Arya, A. K.; Gupta, S. K.; Kumar, M. Tetrahedron Lett. 2012, 53, 6035. http://dx.doi.org/10.1016/j.tetlet.2012.08.099

181. Kumar, M.; Sharma, K.; Arya, A. K. Tetrahedron Lett. 2012, 53, 4604. http://dx.doi.org/10.1016/j.tetlet.2012.06.085

182. Sun, J.; Wu, Q.; Zhang, L.; Yan, C. Chin. J. Chem. 2012, 30, 1548. http://dx.doi.org/10.1002/cjoc.201100657

183. Zhang, L.-J.; Wu, Q.; Sun, J.; Yan, C.-G. Beilstein J. Org. Chem. 2013, 9, 846. http://dx.doi.org/10.3762/bjoc.9.97

184. Gao, H.; Sun, J.; Yan, C. G. J. Org. Chem. 2014, 79, 4131. http://dx.doi.org/10.1021/jo500144z

185. Gao, H.; Sun, J.; Yan, C. G. Mol. Divers. 2014, 18, 511. http://dx.doi.org/10.1007/s11030-014-9512-z 
186. Sun, J.; Sun, Y.; Gao, H.; Yan, C.-G. Eur. J. Org. Chem. 2012, 1976.

http://dx.doi.org/10.1002/ejoc.201101737

187. Debnath, K.; Pramanik, A. Tetrahedron Lett. 2015, 56, 1654.

http://dx.doi.org/10.1016/j.tetlet.2015.02.030

188. Sun, Y.; Sun, J.; Yan, C.-G. Beilstein J. Org. Chem. 2013, 9, 8.

http://dx.doi.org/10.3762/bjoc.9.2

189. Elinson, M. N.; Vereshchagin, A. N.; Nasybullin, R. F.; Bobrovsky, S. I.; Ilovaisky, A. I.;

Merkulova, V. M.; Bushmarinov, I. S.; Egorov, M. P. RSC Adv. 2015, 5, 50421.

http://dx.doi.org/10.1039/c5ra03452c

190. Mahdavinia, G. H.; Mirzazadeh, M.; Notash, B. Tetrahedron Lett. 2013, 54, 3487.

http://dx.doi.org/10.1016/j.tetlet.2013.04.082

191. Shen, T.; Fu, Z.; Che, F.; Dang, H.; Lin, Y.; Song, Q. Tetrahedron Lett. 2015, 56, 1072. http://dx.doi.org/10.1016/j.tetlet.2015.01.062

192. Liu, X.; Xu, X.; Wang, X.; Yang, W.; Qian, Q.; Zhang, M.; Song, L.; Deng, H.; Shao, M. Tetrahedron Lett. 2013, 54, 4451.

http://dx.doi.org/10.1016/j.tetlet.2013.06.038

193. Yu, J.; Zhou, Y.; Shen, T.; Mao, W.; Chen, K.; Song, Q. J. Chem. Res. 2013, 365. http://dx.doi.org/10.3184/174751913X13687116634925

194. Zou, Y.; Hu, Y.; Liu, H.; Shi, D. ACS Comb. Sci. 2012, 14, 38. http://dx.doi.org/10.1021/co200128k

195. Mohammadi Ziarani, G.; Rahimifard, M.; Nouri, F.; Badiei, A. J. Serb. Chem. Soc. In Press, 2015.

http://dx.doi.org/10.2298/JSC140930045M

196. Pore, D. M.; Hegade, P. G.; Gaikwad, D. S.; Patil, P. B.; Patil, J. D. Lett. Org. Chem. 2014, 11,131 .

http://dx.doi.org/10.2174/15701786113106660069

197. Feng, J.; Ablajan, K.; Sali, A. Tetrahedron 2014, 70, 484.

http://dx.doi.org/10.1016/j.tet.2013.11.019

198. Paul, S.; Pradhan, K.; Ghosh, S.; De, S. K.; Das, A. R. Tetrahedron 2014, 70, 6088. http://dx.doi.org/10.1016/j.tet.2014.02.077

199. Hosseinjani-Pirdehi, H.; Rad-Moghadam, K.; Youseftabar-Miri, L. Tetrahedron 2014, 70, 1780 . http://dx.doi.org/10.1016/j.tet.2014.01.025

200. Pore, D. M.; Patil, P. B.; Gaikwad, D. S.; Hegade, P. G.; Patil, J. D.; Undale, K. A. Tetrahedron Lett. 2013, 54, 5876. http://dx.doi.org/10.1016/j.tetlet.2013.08.084

201. Pal, S.; Nasim Khan, M.; Karamthulla, S.; Abbas, S. J.; Choudhury, L. H. Tetrahedron Lett. 2013, 54, 5434. http://dx.doi.org/10.1016/j.tetlet.2013.07.117

202. Wang, C.; Jiang, Y. H.; Yan, C. G. Chin. Chem. Lett. 2015, 26, 889. 


\section{http://dx.doi.org/10.1016/j.cclet.2015.05.018}

203. Alizadeh, A.; Firuzyar, T.; Mikaeili, A. Synthesis 2010, 3913.

http://dx.doi.org/10.1055/s-0030-1258249

204. Ghahremanzadeh, R.; Hosseini, G.; Akbarzadeh, R.; Bazgir, A. J. Heterocycl. Chem. 2013, $50,272$.

http://dx.doi.org/10.1002/jhet.1010

205. Alizadeh, A.; Mikaeili, A.; Firuzyar, T. Synthesis 2012, 44, 1380.

http://dx.doi.org/10.1055/s-0031-1290884

206. Zohreh, N.; Alizadeh, A. ACS Comb. Sci. 2013, 15, 278.

http://dx.doi.org/10.1021/co400005y

207. Alizadeh, A.; Zohreh, N. Synlett 2012, 23, 428.

http://dx.doi.org/10.1055/s-0031-1290322

\section{Authors' Biographies}

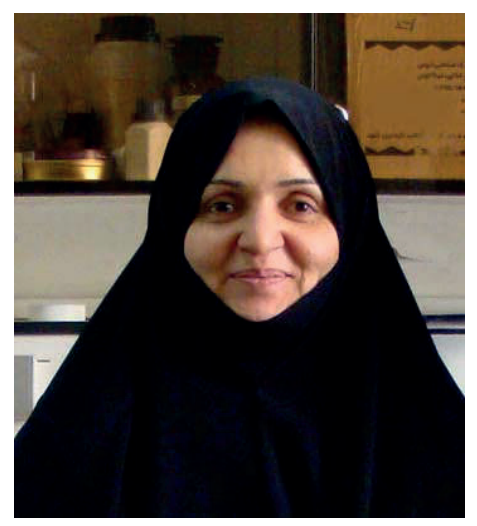

Ghodsi Mohammadi Ziarani was born in Iran, in 1964. She received her B.Sc. degree in Chemistry from the Teacher Training University, Tehran, Iran, in 1987, her M.Sc. degree in Organic Chemistry from the same university, under the supervision of Professor Jafar Asgarin and Professor Mohammad Ali Bigdeli in 1991. She obtained her Ph.D. degree in asymmetric synthesis (Biotransformation) from Laval University, Quebec, Canada under the supervision of Professor Chenevert, in 2000. She is Full Professor in the Science faculty of Alzahra University. Her research interests include organic synthesis, heterocyclic synthesis, asymmetric synthesis, natural products synthesis, synthetic methodology and applications of nano-heterogeneous catalysts in multicomponent reactions. 


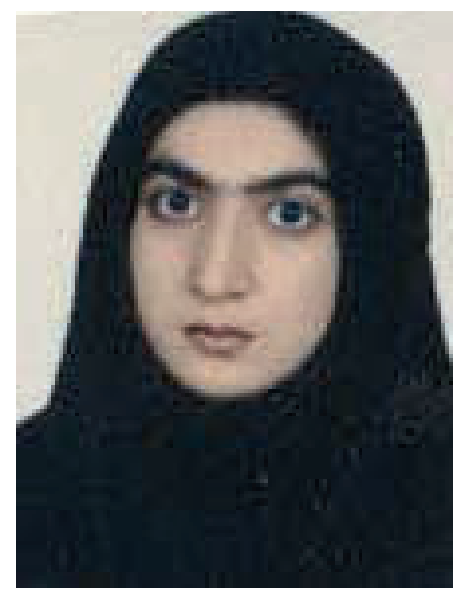

Razieh Moradi was born in 1990 in Delfan, Lorestan, Iran. She obtained her B.Sc. degree in Chemistry from the University of Lorestan (2012). Currently, she is a M.Sc. student in Organic Chemistry at Alzahra University under the supervision of Dr Ghodsi Mohammadi Ziarani. Her research field is on the synthesis of heterocyclic compounds based on isatin and application of nano-heterogeneous catalysts in organic synthesis and multicomponent reactions.

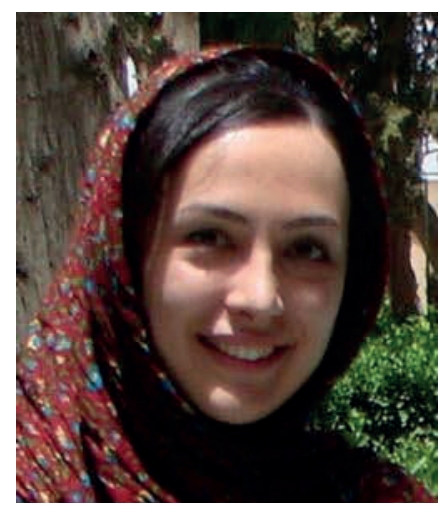

Negar Lashgari was born in 1985 in Tehran, Iran. She received her B.Sc. degree in Applied Chemistry from Tarbiat Moalem University, Tehran, Iran (2008) and her M.Sc. degree in Organic Chemistry at Alzahra University, Tehran, Iran (2011) under the supervision of Dr Ghodsi Mohammadi Ziarani. She is currently working towards her Ph.D. in Nano-Chemistry at the University of Tehran under the supervision of Dr Alireza Badiei and Dr Ghodsi Mohammadi Ziarani. Her research field is synthesis and application of nano-heterogeneous catalysts in multicomponent reactions. 